\title{
The global chemistry transport model TM5: description and evaluation of the tropospheric chemistry version 3.0
}

\author{
V. Huijnen ${ }^{1}$, J. Williams ${ }^{1}$, M. van Weele ${ }^{1}$, T. van Noije ${ }^{1}$, M. Krol ${ }^{2,3,4}$, F. Dentener ${ }^{5}$, A. Segers ${ }^{6}$, S. Houweling ${ }^{3,7}$, \\ W. Peters ${ }^{2,8}$, J. de Laat ${ }^{1}$, F. Boersma ${ }^{1}$, P. Bergamaschi ${ }^{5}$, P. van Velthoven ${ }^{1}$, P. Le Sager ${ }^{1}$, H. Eskes ${ }^{1}$, F. Alkemade ${ }^{1}$, \\ R. Scheele ${ }^{1}$, P. Nédélec ${ }^{9}$, and H.-W. Pätz ${ }^{10}$ \\ ${ }^{1}$ Royal Netherlands Meteorological Institute, De Bilt, The Netherlands \\ ${ }^{2}$ Dept. of Meteorology and Air Quality, Wageningen University, Wageningen, The Netherlands \\ ${ }^{3}$ SRON Netherlands Institute for Space Research, Utrecht, The Netherlands \\ ${ }^{4}$ Institute for Marine and Atmospheric Research Utrecht (IMAU), Utrecht, The Netherlands \\ ${ }^{5}$ European Commission, Joint Research Centre, Institute for Environment and Sustainability, 21027 Ispra (VA), Italy \\ ${ }^{6} \mathrm{TNO}$ Built Environment and Geosciences, Department of Air Quality and Climate, Utrecht, The Netherlands \\ ${ }^{7}$ Institute for Marine and Atmospheric Research Utrecht (IMAU), Utrecht, The Netherlands \\ ${ }^{8}$ NOAA Earth System Research Laboratory, Boulder, CO, USA \\ ${ }^{9}$ CNRS, Laboratoire d'Aérologie, 31400 Toulouse, France \\ ${ }^{10}$ ICG-2, Forschungszentrum Jülich, Jülich, Germany
}

Received: 8 June 2010 - Published in Geosci. Model Dev. Discuss.: 7 July 2010

Revised: 13 September 2010 - Accepted: 16 September 2010 - Published: 6 October 2010

\begin{abstract}
We present a comprehensive description and benchmark evaluation of the tropospheric chemistry version of the global chemistry transport model TM5 (Tracer Model 5, version TM5-chem-v3.0). A full description is given concerning the photochemical mechanism, the interaction with aerosol, the treatment of the stratosphere, the wet and dry deposition parameterizations, and the applied emissions. We evaluate the model against a suite of ground-based, satellite, and aircraft measurements of components critical for understanding global photochemistry for the year 2006.

The model exhibits a realistic oxidative capacity at a global scale. The methane lifetime is $\sim 8.9$ years with an associated lifetime of methyl chloroform of 5.86 years, which is similar to that derived using an optimized hydroxyl radical field.

The seasonal cycle in observed carbon monoxide (CO) is well simulated at different regions across the globe. In the Northern Hemisphere CO concentrations are underestimated by about $20 \mathrm{ppbv}$ in spring and $10 \mathrm{ppbv}$ in summer, which is related to missing chemistry and underestimated emissions from higher hydrocarbons, as well as to uncertainties in the
\end{abstract}

Correspondence to: V. Huijnen

(huijnen@knmi.nl) seasonal variation of $\mathrm{CO}$ emissions. The model also captures the spatial and seasonal variation in formaldehyde tropospheric columns as observed by SCIAMACHY. Positive model biases over the Amazon and eastern United States point to uncertainties in the isoprene emissions as well as its chemical breakdown.

Simulated tropospheric nitrogen dioxide columns correspond well to observations from the Ozone Monitoring Instrument in terms of its seasonal and spatial variability (with a global spatial correlation coefficient of 0.89), but TM5 fields are lower by $25-40 \%$. This is consistent with earlier studies pointing to a high bias of $0-30 \%$ in the OMI retrievals, but uncertainties in the emission inventories have probably also contributed to the discrepancy.

TM5 tropospheric nitrogen dioxide profiles are in good agreement (within $\sim 0.1 \mathrm{ppbv}$ ) with in situ aircraft observations from the INTEX-B campaign over (the Gulf of) Mexico.

The model reproduces the spatial and seasonal variation in background surface ozone concentrations and tropospheric ozone profiles from the World Ozone and Ultraviolet Radiation Data Centre to within $10 \mathrm{ppbv}$, but at several tropical stations the model tends to underestimate ozone in the free troposphere.

Published by Copernicus Publications on behalf of the European Geosciences Union. 
The presented model results benchmark the TM5 tropospheric chemistry version, which is currently in use in several international cooperation activities, and upon which future model improvements will take place.

\section{Introduction}

To assess the impacts and potential consequences of emissions and changing climate on the composition of the atmosphere requires the development of detailed large-scale computer models. TM5 (Tracer Model, version 5) is one such tool, being a three-dimensional global atmospheric chemistry transport model with an option for two-way nested zooming in the horizontal domain (Krol et al., 2005). This advanced tool has the ability to simulate the composition of the atmosphere from a global scale down to regional scales with a resolution of $0.5^{\circ} \times 0.25^{\circ}$ (longitude $\times$ latitude) .

The TM5 model evolved from the original TM2 model (Heimann et al., 1988), TM3 (Houweling et al., 1998; Dentener et al., 2003) and TM4 (Williams et al., 2009a) model. Some elements of the original concepts and parameterizations are still found in the current TM5 model.

The TM5 model framework is applied for inversion studies (e.g. Meirink et al., 2008; Krol et al., 2008; Peters et al., 2009; Bergamaschi et al., 2009), aerosol modeling (de Meij et al., 2006; Vignati et al., 2010), stratospheric chemistry modeling (e.g. Van den Broek et al., 2003), ozone profile assimilation (e.g. De Laat et al., 2007, 2009), and chemical weather and climate simulations, where TM5 is coupled to a meteorological model such as the Integrated Forecasting System (IFS) (Flemming et al., 2009) and applied in the Earth System model EC-Earth (Hazeleger et al., 2010). The tropospheric chemistry version of TM5 has recently participated in the ACCENT (Atmospheric Composition Change, the European Network of Excellence) model intercomparison project (e.g. Dentener et al., 2006a; and references therein), the GEMS (Global and regional Earth-system (atmosphere) Monitoring using Satellite and in-situ data) project (Ordóñez et al., 2010; Huijnen et al., 2010), the Transcom Continuous model intercomparison project (Law et al., 2008) and a study conducted by the Task Force on Hemispheric Transport of Air Pollution (TF HTAP; Fiore et al., 2009).

All applications of TM5 share at least the methods for the model discretization, the operator splitting (Krol et al., 2005), the treatment of the meteorological fields, and the mass conserving tracer transport (Bregman et al., 2003). The model is written in the Fortran 90 programming language, where parallelization is implemented based on a combination of MPI and OpenMP.

As is shown in the overview above, the TM5 user community, diversity of applications, affiliations of authors and consequently also the amount of model permutations and improvements have substantially increased. Therefore, it is im- portant to provide a comprehensive overview of a benchmark version, and corresponding results, to provide the framework upon which future improvements can take place. The focus of this paper is on the evaluation of the photochemistry of the global troposphere of the benchmark version, which is named TM5-chem-v3.0. This model version is archived in a web accessible version control system release 3304 and is in use in the GEMS, MACC (Monitoring Atmospheric Composition and Climate), GEOMON (Global Earth Observation and Monitoring) and EC-Earth projects. We evaluate the major components of importance for describing background tropospheric photochemical processes in the boundary layer and free troposphere: ozone $\left(\mathrm{O}_{3}\right)$ and related tracers like nitrogen oxides $\left(\mathrm{NO}_{\mathrm{x}}\right)$, carbon monoxide $(\mathrm{CO})$, methane $\left(\mathrm{CH}_{4}\right)$, and non-methane volatile organic compounds (NMVOC). As indicated above, other TM5 versions focus on different science issues, e.g. aerosol chemistry, or inversions of $\mathrm{CO}_{2}$ and $\mathrm{CH}_{4}$. Providing benchmark evaluation for these versions is beyond the scope of this paper.

In Sect. 2 we give an overview of the general setup of TM5 and describe the horizontal and vertical grids employed, the meteorology used to drive the model, the operator splitting, and the advection scheme and physical parameterizations used for convective transport and vertical mixing. In Sect. 3 we describe the gas-phase reaction scheme, the photolysis parameterization, the heterogeneous reactions included, the chemical solver, the description of aerosol processes, and the representation of the stratosphere. In Sect. 4 an overview of dry and wet deposition parameterizations and emission inventories is provided. In Sect. 5 we evaluate the performance of the model using a simulation for the year 2006, and show that the model has the ability to reproduce the large-scale variability in both space and time. Evaluation metrics and TM5 results from the ACCENT model intercomparison are used to quantify recent model improvements. For selected topics, a detailed description is left for Appendices A (methyl chloroform) and B (surface ozone).

\section{General model setup}

\subsection{Grid and zoom regions}

TM5 allows a two-way nesting of regions as described in Krol et al. (2005). A grid configuration using zoom regions may consist of a global domain of $6^{\circ} \times 4^{\circ}$ or $3^{\circ} \times 2^{\circ}$, an intermediate zoom region with higher resolution, and a target zoom region of for instance $1^{\circ} \times 1^{\circ}$ or $0.5^{\circ} \times 0.25^{\circ}$, which is embedded in the intermediate domain (e.g. van Loon et al., 2007; Aan den Brugh et al., 2010).

The standard resolution of the TM5-chem-v3.0 model in this benchmark study is $3^{\circ} \times 2^{\circ}$. In the polar regions $(>$ $80^{\circ} \mathrm{N} / \mathrm{S}$ ) the number of grid cells in the longitudinal direction is gradually reduced towards the poles to avoid violation 
of Courant-Friedrichs-Lewy (CFL) criteria (Bregman et al., 2003).

In the vertical domain a subset of levels are chosen out of either the standard 60 (ERA-Interim reanalysis) or 91 hybrid sigma-pressure levels (operational data since ECMWF cycle 30r1) of the forecast and reanalysis model of the European Centre for Medium-Range Weather Forecasts (ECMWF). The vertical distribution is chosen such that it covers the full domain of the ECMWF model, i.e. including the middle atmosphere, while having especially good vertical resolution in the planetary boundary layer and in the tropopause region to resolve possibly steep tracer gradients. The model typically uses 34 vertical layers, where the model top is set at $0.1 \mathrm{hPa}$.

\subsection{Meteorology}

The meteorological fields used to drive the model are derived from the ECMWF operational forecast data (stored at T319, which corresponds to a horizontal grid resolution of $\sim 0.56^{\circ}$ ) or from the ERA-Interim reanalysis (at T255, which corresponds to $\left.\sim 0.7^{\circ}\right)$. Normally the data is preprocessed onto a global $1^{\circ} \times 1^{\circ}$ grid (Krol et al., 2005). Mass fluxes are computed as described in Segers et al. (2002). Most meteorological data is preprocessed and stored on a three-hourly frequency, where either the time averaged or hourly interpolated data are used. For simulations at a higher spatial resolution (e.g. $0.5^{\circ} \times 0.25^{\circ}$ ), either the $1^{\circ} \times 1^{\circ}$ data interpolated to the higher resolution can be used, or dedicated regional meteorological fields can be created based on high-resolution ECMWF data, as done in this study. Table 1 lists the variables that are required by TM5, including the standard time interpolation.

\subsection{Operator splitting and time stepping}

TM5 adopts an operator splitting algorithm in the time stepping procedure. It consists of the following operations: advection in the horizontal $(\mathrm{X}, \mathrm{Y})$ and vertical $(\mathrm{Z})$ directions, vertical mixing $(\mathrm{V})$, chemistry $(\mathrm{C})$, and sources/sinks (S). In the global domain the order of the operations during a base time step $\Delta t$ is given in Schematic (1) below:

$$
\text { (XYZVSC) (CSVZYX). }
$$

Each operation is performed twice in a symmetrical order, thus all individual operations are performed for a time step of $\Delta t / 2$. For simulations where zooming is applied, communication to the zoom regions is performed before the first and after the second sequence of operations, i.e. at the start and end of the sequence shown in Schematic (1). The mathematical foundations of the mass-conserving advection scheme used in the zoom algorithm, including transport to and from the zoom regions, is described in Berkvens et al. (1999). The nesting algorithm applies communication in two directions between a parent region and its child region of a higher resolution i.e. the parent provides boundary conditions to its
Table 1. Meteorological data from the ECMWF used in TM5. All surface related parameters are on a $1^{\circ} \times 1^{\circ}$ horizontal resolution. Here "interp3/6" denote an hourly temporal interpolation between $3 / 6$ hourly fields, "aver3" denotes 3-hourly time averaged fields and "const" denotes invariant fields during a day.

\begin{tabular}{lll}
\hline Field & Unit & $\begin{array}{l}\text { Temporal } \\
\text { resolution }\end{array}$ \\
\hline Surface pressure & $\mathrm{Pa}$ & interp3 \\
Temperature & $\mathrm{K}$ & interp3 \\
Specific humidity & $\mathrm{kg} / \mathrm{kg}$ & interp3 \\
u/v/w mass fluxes & $\mathrm{kg} / \mathrm{s}$ & interp3 \\
cloud liquid/ice water content & $\mathrm{kg} / \mathrm{kg}$ & interp3 \\
Fractional cloud cover & $0-1$ & interp3 \\
Convective precipitation & $\mathrm{m} / \mathrm{s}$ & aver3 \\
Large-scale stratiform precipitation & $\mathrm{m} / \mathrm{s}$ & aver3 \\
Surface sensible/latent heat fluxes & $\mathrm{W} / \mathrm{m}^{2}$ & aver3 \\
10-m u/v wind field & $\mathrm{m} / \mathrm{s}$ & aver3 \\
Surface roughness & $\mathrm{m}$ & interp6 \\
Olsson surface roughness & $\mathrm{m}$ & monthly \\
Surface stress & $\mathrm{m} / \mathrm{s}$ & aver3 \\
Land/sea fraction & $0-1$ & const \\
Sea ice fraction & $0-1$ & const \\
Surface solar radiation & $\mathrm{W} / \mathrm{m}^{2}$ & aver3 \\
2-m temperature & $\mathrm{K}$ & aver3 \\
2-m dewpoint temperature & $\mathrm{K}$ & aver3 \\
Skin reservoir content & $\mathrm{m} \mathrm{water}$ & aver3 \\
Snow depth & $\mathrm{m} \mathrm{water} \mathrm{eqv.}$ & aver3 \\
Volumetric soil water in top soil layer & $\mathrm{m} 3 / \mathrm{m}^{3}$ & aver3 \\
Vegetation type fractions & $0-1$ & const \\
Low/high vegetation cover fractions & $0-1$ & const \\
\hline
\end{tabular}

child, and vice versa the parent tracer masses are updated at the boundaries according to the values calculated in overlapping cells of the child region. Chemistry and vertical transport in the overlapping grid cells is only applied in the parent cells.

In the standard spatial resolution of $3^{\circ} \times 2^{\circ}$ the base time step $\Delta t$ is one hour, resulting in a time step of $\Delta t / 2=0.5 \mathrm{~h}$ for all individual operations. Additionally the time step is dynamically reduced in case the CFL stability criterion for tracer advection is not fulfilled (Bregman et al., 2003). The time steps within each sub-process can be adapted independently, if required to improve stability and accuracy. For instance, solution of the chemical differential equations is performed using a standard time step of $0.25 \mathrm{~h}$.

Except for the advection steps (XYZ), some parameterizations that, strictly speaking, belong to specific operations are applied elsewhere in the sequence:

(V) The vertical mixing includes a parameterization of sub-grid scale mixing by deep convection and vertical diffusion. Also scavenging due to convective precipitation is applied here, integrated in the convection routine. 
Table 2. The chemical trace species which are included in the tropospheric chemistry version of TM5. The definitions of the lumped species, aerosols and operators are: [1] paraffinic carbon atoms, [2] olefinic carbon bonds, [3] $\mathrm{CH}_{3} \mathrm{CHO}$ and higher aldehydes, [4] higher organic peroxides, [5] alkyl nitrates, [6] sulphate aerosol, [7] nitrate aerosol, [8] ammonium aerosol, [9] organic ethers, [10] PAR budget corrector, [11] $\mathrm{NO}$ to $\mathrm{NO}_{2}$ operator and [12] NO to alkyl nitrate operator. The $\mathrm{O}\left({ }^{1} \mathrm{D}\right)$ species is not specifically included in the scheme. The chemical trace species that are not transported are shown in blue.

\begin{tabular}{ccc}
\hline Chemical trace species & (continued) & (continued) \\
\hline $\mathrm{O}_{3}$ & $\mathrm{ORGNTR}^{[5]}$ & $\mathrm{OH}$ \\
$\mathrm{NO}_{\mathrm{x}}$ & $\mathrm{ISOP}$ & $\mathrm{NO}_{2}$ \\
$\mathrm{H}_{2} \mathrm{O}_{2}$ & $\mathrm{SO}_{2}$ & $\mathrm{NO}_{3}$ \\
$\mathrm{CH}_{4}$ & $\mathrm{DMS}$ & $\mathrm{N}_{2} \mathrm{O}_{5}$ \\
$\mathrm{CO}$ & $\mathrm{NH}_{3}$ & $\mathrm{HNO}_{4}$ \\
$\mathrm{HNO}_{3}$ & $\mathrm{NH}_{4}^{+[8]}$ & $\mathrm{CH}_{3} \mathrm{COCHO}$ \\
$\mathrm{CH}_{3} \mathrm{OOH}$ & $\mathrm{MSA}^{2}$ & $\mathrm{C}_{2} \mathrm{O}_{3}$ \\
$\mathrm{CH}_{2} \mathrm{O}$ & $\mathrm{SO}_{4}^{2-[6]}$ & $\mathrm{ROR}^{[9]}$ \\
$\mathrm{PAR}^{[1]}$ & $\mathrm{NO}_{3}^{-[7]}$ & $\mathrm{RXPAR}^{[10]}$ \\
$\mathrm{C}_{2} \mathrm{H}_{4}$ & $222 \mathrm{Rn}$ & $\mathrm{XO}_{2}[11]$ \\
$\mathrm{OLE}^{[2]}$ & $210 \mathrm{~Pb}$ & $\mathrm{XO}_{2} \mathrm{~N}^{[12]}$ \\
$\mathrm{ALD}^{[3]}$ & $\mathrm{NO}^{31}$ & $\mathrm{NH}_{2}$ \\
$\mathrm{PAN}^{[4]}$ & $\mathrm{HO}_{2}$ & \\
$\mathrm{ROOH}^{[4]}$ & $\mathrm{CH}_{3} \mathrm{O}_{2}$ & \\
\hline
\end{tabular}

(S) The sources/sinks operator includes the application of emissions and stratospheric boundary conditions, as well as the wet removal due to large-scale precipitation.

(C) The chemistry step contains the application of the chemistry and photolysis schemes, the application of dry deposition and nitric oxide (NO) emissions, which are integral parts of the chemical solver. NO emissions are coupled to the chemistry because of the numerical stiffness of the NO$\mathrm{NO}_{2}-\mathrm{O}_{3}$ photostationary state and their fast interaction.

For a description of these individual sub-processes the reader is referred to the sections below.

\subsection{Tracer transport}

The standard advection algorithm in TM5 is based on the slopes scheme developed by Russell and Lerner (1981). The model also has the option of using the second-order moments scheme (Prather, 1986), but this has not been used in the evaluation presented in this paper. The second-order moments scheme has recently been shown to improve the transport in the upper troposphere and lower stratosphere (UTLS) when applied in TM5 (Bönisch et al., 2008), but at increased computational expense. Both deep and shallow cumulus convection is evaluated according to the Tiedtke scheme (1989). In the free troposphere vertical diffusion is computed based on wind shear and static stability following Louis (1979), while in the planetary boundary layer vertical diffusion is parameterized based on the revised LTG (Louis, Tiedtke and Geleyn) scheme of Holtslag and Boville (1993). The scheme explicitly accounts for stable conditions in the surface layer using Monin-Obukhov similarity theory. The diurnal variation of the boundary layer height is determined following Vogelezang and Holtslag (1996) from 3-hourly ECMWF surface latent and sensible heat fluxes in combination with temperature and humidity vertical profiles. The performance of this combination of parameterizations has been evaluated by Peters et al. (2004) using sulphur hexafluoride $\left(\mathrm{SF}_{6}\right)$ simulations.

\section{Tropospheric chemistry}

\subsection{Gas-phase reaction scheme}

The chemical mechanism is an updated version of the modified Carbon Bond Mechanism 4 (CBM4) scheme described in Houweling et al. (1998), which is based on the CBM4 mechanism of Gery et al. (1989). The CBM4 scheme adopts a lumping approach for organic trace gas species by defining a separate tracer species for specific types of functional groups (e.g. ALD2 represents higher aldehydes). The speciation of the explicit organic compounds that are introduced in terms of lumped species follows the recommendations given in Yarwood et al. (2005).

The scheme is supplemented with chemical reactions for the oxidation of sulphur dioxide $\left(\mathrm{SO}_{2}\right)$, di-methyl sulphide (DMS), methyl sulphonic acid (MSA) and ammonia $\left(\mathrm{NH}_{3}\right)$. For the oxidation of DMS, the approach of Chin et al. (1996) is adopted. Table 2 gives a comprehensive list of the trace gases included in the chemical scheme. In total there are 27 transported chemical species, including the radioactive tracers radon $\left({ }^{222} \mathrm{Rn}\right)$ and lead $\left({ }^{210} \mathrm{~Pb}\right)$, and 15 non-transported ("short-lived") chemical species, mainly free radicals. The nitrogen oxide species $\mathrm{NO}$ and $\mathrm{NO}_{2}$, the nitrate radical $\left(\mathrm{NO}_{3}\right), \mathrm{N}_{2} \mathrm{O}_{5}$ and $\mathrm{HNO}_{4}$ are transported as a lumped aggregate. Separate tracers are used for transporting nitrate aerosol $\left(\mathrm{NO}_{3}^{-}\right)$and sulphate aerosol $\left(\mathrm{SO}_{4}^{2-}\right)$.

The reaction rates have been updated according to the latest recommendations given in either Sander et al. (2006) or Atkinson et al. (2004, 2006). The oxidation of $\mathrm{CO}$ by $\mathrm{OH}$ implicitly accounts for the formation and subsequent decomposition of the intermediate species HOCO as outlined in Sander et al. (2006). For lumped species such as ALD2, the reaction rate is determined using an average of the rates of reaction for the $\mathrm{C} 2$ and $\mathrm{C} 3$ aldehydes, which are considered to be the most abundant. For OLE, which represents olefinic bonds (carbon double bonds), the average of the rates of reaction for the oxidation of propene, methacrolein and methyl vinyl ketone with each respective oxidant is used. There are also some special cases concerning the lumped radical operator species $\mathrm{XO}_{2}$ and $\mathrm{XO}_{2} \mathrm{~N}$. For the self-reaction of $\mathrm{XO}_{2}$ an 
Table 3. The gas-phase chemical mechanism applied in the tropospheric chemistry version of TM5. The reaction products $\mathrm{O}_{2}$ and $\mathrm{H}_{2} \mathrm{O}$ are not shown. The reactions involving $\mathrm{SO}_{2}$, DMS and $\mathrm{NH} 3$ have been added onto the modified CBM4 scheme of Houweling et al. (1998) in order to account for the oxidation of the respective species. All reactions of the $\mathrm{NH} 2$ radical act as sink processes for the respective radicals and oxidants. The source of the rate data is as follows: [1] Sander et al. (2006), [2] Yarwood et al. (2005), [3] Atkinson et al. (2006), [4] Gery et al. (1989), [5] Houweling et al. (1998), and [6] Atkinson et al. (2004).

\begin{tabular}{|c|c|c|c|}
\hline Reactants & Products & Rate expression & Reference \\
\hline $\mathrm{NO}+\mathrm{O}_{3}$ & $\mathrm{NO}_{2}$ & $3.0 \mathrm{E}-12 * \exp (-1500 / \mathrm{T})$ & {$[1]$} \\
\hline $\mathrm{NO}+\mathrm{HO}_{2}$ & $\mathrm{NO}_{2}+\mathrm{OH}$ & $3.5 \mathrm{E}-12 * \exp (250 / \mathrm{T})$ & {$[1]$} \\
\hline $\mathrm{NO}+\mathrm{CH}_{3} \mathrm{O}_{2}$ & $\mathrm{CH}_{2} \mathrm{O}+\mathrm{HO}_{2}+\mathrm{NO}_{2}$ & $2.8 \mathrm{E}-12 * \exp (300 / \mathrm{T})$ & {$[1]$} \\
\hline $\mathrm{NO}_{2}+\mathrm{OH}(+\mathrm{M})$ & $\mathrm{HNO}_{3}$ & $\begin{array}{l}\mathrm{K}_{0}=1.8 \mathrm{E}-30 *(300 / \mathrm{T})^{3.0} \\
\mathrm{~K}_{\infty}=2.8 \mathrm{E}-11\end{array}$ & {$[1]$} \\
\hline $\mathrm{OH}+\mathrm{HNO}_{3}$ & $\mathrm{NO}_{3}$ & $\begin{array}{l}\mathrm{K}_{0}=2.41 \mathrm{E}-14 *(460 / \mathrm{T}) \\
\mathrm{K}_{2}=6.51 \mathrm{E}-34 *(1335 / \mathrm{T}) \\
\mathrm{K}_{3}=2.69 \mathrm{E}-17 *(2199 / \mathrm{T})\end{array}$ & {$[1]$} \\
\hline $\mathrm{NO}_{2}+\mathrm{O}_{3}$ & $\mathrm{NO}_{3}$ & $1.2 \mathrm{E}-13 * \exp (-2540 / \mathrm{T})$ & {$[1]$} \\
\hline $\mathrm{NO}+\mathrm{NO}_{3}$ & $\mathrm{NO}_{2}+\mathrm{NO}_{2}$ & $1.5 \mathrm{E}-11 * \exp (170 / \mathrm{T})$ & {$[1]$} \\
\hline $\mathrm{NO}_{2}+\mathrm{NO}_{3}$ & $\mathrm{~N}_{2} \mathrm{O}_{5}$ & $\begin{array}{l}\mathrm{K}_{0}=2.0 \mathrm{E}-30 *(300 / \mathrm{T})^{4.4} \\
\mathrm{~K}_{\infty}=1.4 \mathrm{E}-12 *(300 / \mathrm{T})^{0.7}\end{array}$ & {$[1]$} \\
\hline $\mathrm{N}_{2} \mathrm{O}_{5}$ & $\mathrm{NO}_{2}+\mathrm{NO}_{3}$ & $2.7 \mathrm{E}-27 * \exp (11000 / \mathrm{T})$ & {$[1]$} \\
\hline $\mathrm{OH}+\mathrm{HNO}_{4}$ & $\mathrm{NO}_{2}$ & $1.3 \mathrm{E}-12 * \exp (380 / \mathrm{T})$ & {$[1]$} \\
\hline $\mathrm{NO}_{2}+\mathrm{HO}_{2}$ & $\mathrm{HNO}_{4}$ & $\begin{array}{l}\mathrm{K}_{0}=2.0 \mathrm{E}-31 *(300 / \mathrm{T})^{3.4} \\
\mathrm{~K}_{\infty}=2.9 \mathrm{E}-12 *(300 / \mathrm{T})^{1.1}\end{array}$ & {$[1]$} \\
\hline $\mathrm{HNO}_{4}(+\mathrm{M})$ & $\mathrm{NO}_{2}+\mathrm{HO}_{2}$ & $2.1 \mathrm{E}-27 * \exp (10900 / \mathrm{T})$ & {$[1]$} \\
\hline $\mathrm{O}\left({ }^{1} \mathrm{D}\right)(+\mathrm{M})$ & & $\begin{array}{l}3.3 \mathrm{E}-11 * \exp (55 / \mathrm{T}) *\left[\mathrm{O}_{2}\right] \\
+2.15 \mathrm{E} 11 * \exp (110 / \mathrm{T}) *\left[\mathrm{~N}_{2}\right]\end{array}$ & {$[1]$} \\
\hline $\mathrm{O}\left({ }^{1} \mathrm{D}\right)+\mathrm{H}_{2} \mathrm{O}$ & $\mathrm{OH}+\mathrm{OH}$ & $1.63 \mathrm{E}-10 * \exp (60 / \mathrm{T})$ & {$[1]$} \\
\hline $\mathrm{O}_{3}+\mathrm{HO}_{2}$ & $\mathrm{OH}$ & $1.0 \mathrm{E}-14 * \exp (-490 / \mathrm{T})$ & {$[1]$} \\
\hline $\mathrm{CO}+\mathrm{OH}$ & $\mathrm{HO}_{2}$ & $\begin{array}{l}\mathrm{K}_{0}=5.9 \mathrm{E}-33 *(300 / \mathrm{T})^{1.4} \\
\mathrm{~K}_{\infty}=1.1 \mathrm{E}-12 *(300 / \mathrm{T})^{-1.3} \\
\mathrm{~K}_{0}=1.5 \mathrm{E}-13 *(300 / \mathrm{T})^{-0.6} \\
\mathrm{~K}_{\infty}=2.1 \mathrm{E} 9 *(300 / \mathrm{T})^{-6.1}\end{array}$ & {$[1]$} \\
\hline $\mathrm{O}_{3}+\mathrm{OH}$ & $\mathrm{HO}_{2}$ & $1.7 \mathrm{E}-12 * \exp (-940 / \mathrm{T})$ & {$[1]$} \\
\hline $\mathrm{OH}+\mathrm{H}_{2} \mathrm{O}_{2}$ & $\mathrm{HO}_{2}$ & $1.8 \mathrm{E}-12$ & {$[1]$} \\
\hline $\mathrm{OH}+\mathrm{CH}_{2} \mathrm{O}$ & $\mathrm{CO}+\mathrm{HO}_{2}$ & $5.5 \mathrm{E}-12 * \exp (125 / \mathrm{T})$ & {$[1]$} \\
\hline $\mathrm{OH}+\mathrm{CH}_{4}$ & $\mathrm{CH}_{3} \mathrm{O}_{2}$ & $2.45 \mathrm{E}-12 * \exp (-1775 / \mathrm{T})$ & {$[1]$} \\
\hline $\mathrm{OH}+\mathrm{CH}_{3} \mathrm{OOH}$ & $0.7 \mathrm{CH}_{3} \mathrm{O}_{2}+0.3 \mathrm{CH}_{2} \mathrm{O}+0.3 \mathrm{OH}$ & $3.8 \mathrm{E}-12 * \exp (200 / \mathrm{T})$ & {$[1]$} \\
\hline $\mathrm{OH}+\mathrm{ROOH}$ & $0.7 \mathrm{XO}_{2}+0.3 \mathrm{OH}$ & $3.01 \mathrm{E}-12 * \exp (190 / \mathrm{T})$ & [2] \\
\hline $\mathrm{CH}_{3} \mathrm{O}_{2}+\mathrm{HO}_{2}$ & $\mathrm{CH}_{3} \mathrm{OOH}$ & $4.1 \mathrm{E}-13 * \exp (750 / \mathrm{T})$ & {$[1]$} \\
\hline $\mathrm{CH}_{3} \mathrm{O}_{2}+\mathrm{CH}_{3} \mathrm{O}_{2}$ & $1.33 \mathrm{CH}_{2} \mathrm{O}+0.67 \mathrm{HO}_{2}$ & $9.5 \mathrm{E}-14 * \exp (390 / \mathrm{T})$ & [1] \\
\hline $\mathrm{OH}+\mathrm{HO}_{2}$ & & $4.8 \mathrm{E}-11 * \exp (250 / \mathrm{T})$ & {$[1]$} \\
\hline $\mathrm{HO}_{2}+\mathrm{HO}_{2}$ & $\mathrm{H}_{2} \mathrm{O}_{2}$ & $\begin{array}{l}3.5 \mathrm{E}-13 * \exp (430 / \mathrm{T}) \\
1.77 \mathrm{E}-33 * \exp (1000 / \mathrm{T}) \\
1.4 \mathrm{E}-21 * \exp (2200 / \mathrm{T})\end{array}$ & {$[1]$} \\
\hline $\mathrm{OH}+\mathrm{H}_{2}$ & $\mathrm{HO}_{2}$ & $2.8 \mathrm{E}-12 * \exp (-1800 / \mathrm{T})$ & {$[1]$} \\
\hline $\mathrm{NO}_{3}+\mathrm{CH}_{2} \mathrm{O}$ & $\mathrm{HNO}_{3}+\mathrm{CO}+\mathrm{HO}_{2}$ & $5.8 \mathrm{E}-16$ & {$[1]$} \\
\hline $\mathrm{ALD} 2+\mathrm{OH}$ & $\mathrm{C}_{2} \mathrm{O}_{3}$ & $\begin{array}{l}\text { Average of : } \\
4.4 \mathrm{E}-12 * \exp (365 / \mathrm{T}) \\
5.1 \mathrm{E}-12 * \exp (405 / \mathrm{T})\end{array}$ & $\begin{array}{l}{[3]} \\
{[3]}\end{array}$ \\
\hline $\mathrm{ALD} 2+\mathrm{NO}_{3}$ & $\mathrm{C}_{2} \mathrm{O}_{3}+\mathrm{HNO}_{3}$ & $\begin{array}{l}\text { Average of : } \\
1.4 \mathrm{E}-12 * \exp (-1860 / \mathrm{T}) \\
6.5 \mathrm{E}-15\end{array}$ & $\begin{array}{l}{[3]} \\
{[3]}\end{array}$ \\
\hline $\mathrm{NO}+\mathrm{C}_{2} \mathrm{O}_{3}$ & $\mathrm{CH}_{2} \mathrm{O}+\mathrm{XO}_{2}+\mathrm{HO}_{2}+\mathrm{NO}_{2}$ & $8.1 \mathrm{E}-12 * \exp (270 / \mathrm{T})$ & {$[1]$} \\
\hline $\mathrm{NO}_{2}+\mathrm{C}_{2} \mathrm{O}_{3}$ & PAN & $\begin{array}{l}\mathrm{K}_{0}=2.7 \mathrm{E}-28 *(300 / \mathrm{T})^{7.1} \\
\mathrm{~K}_{\infty}=1.2 \mathrm{E}-11 *(300 / \mathrm{T}){ }^{0.9}\end{array}$ & {$[3]$} \\
\hline
\end{tabular}


Table 3. Continued.

\begin{tabular}{|c|c|c|c|}
\hline Reactants & Products & Rate expression & Reference \\
\hline PAN & $\mathrm{NO}_{2}+\mathrm{C}_{2} \mathrm{O}_{3}$ & $\begin{array}{l}\mathrm{K}_{0}=4.9 \mathrm{E}-3 * \exp (-12100 / \mathrm{T}) \\
\mathrm{K}_{\infty}=5.4 \mathrm{E} 16 * \exp (-13830 / \mathrm{T})\end{array}$ & {$[3]$} \\
\hline $\mathrm{C}_{2} \mathrm{O}_{3}+\mathrm{C}_{2} \mathrm{O}_{3}$ & $2 \mathrm{CH}_{2} \mathrm{O}+2 \mathrm{XO}_{2}+2 \mathrm{HO}_{2}$ & $2.9 \mathrm{E}-12 * \exp (500 / \mathrm{T})$ & {$[1]$} \\
\hline $\mathrm{C}_{2} \mathrm{O}_{3}+\mathrm{HO}_{2}$ & $\begin{array}{l}\mathrm{CH}_{2} \mathrm{O}+\mathrm{XO}_{2}+\mathrm{HO}_{2}+ \\
0.79 \mathrm{OH}+0.21 \mathrm{ROOH}\end{array}$ & $4.3 \mathrm{E}-13 * \exp (1040 / \mathrm{T})$ & {$[1]$} \\
\hline $\mathrm{OH}+\mathrm{PAR}$ & $\begin{array}{l}0.87 \mathrm{XO}_{2}+0.76 \mathrm{ROR}+0.11 \mathrm{HO}_{2}+ \\
0.11 \mathrm{ALD} 2+0.11 \mathrm{RXPAR}+0.13 \mathrm{XO}_{2} \mathrm{~N}\end{array}$ & $8.1 \mathrm{E}-13$ & {$[4]$} \\
\hline ROR & $\begin{array}{l}\text { 1.1 } \mathrm{ALD} 2+0.96 \mathrm{XO}_{2}+0.04 \mathrm{XO}_{2} \mathrm{~N}+ \\
0.02 \mathrm{ROR}+2.1 \mathrm{RXPAR}+0.94 \mathrm{HO}_{2}\end{array}$ & $1 \mathrm{E} 15 * \exp (-8000 / \mathrm{T})$ & [4] \\
\hline ROR & $\mathrm{HO}_{2}$ & $1600.0^{(*)}$ & {$[4]$} \\
\hline $\mathrm{OH}+\mathrm{OLE}$ & $\mathrm{CH}_{2} \mathrm{O}+\mathrm{ALD} 2+\mathrm{XO}_{2}+\mathrm{HO}_{2}+\mathrm{RXPAR}$ & $\begin{array}{l}\text { Average of : } \\
1.86 \mathrm{E}-11 * \exp (175 / \mathrm{T}) \\
8.12 \mathrm{E}-12 * \exp (610 / \mathrm{T}) \\
2.6 \mathrm{E}-12 * \exp (610 / \mathrm{T})\end{array}$ & $\begin{array}{l}{[3]} \\
{[3]} \\
{[3]}\end{array}$ \\
\hline $\mathrm{O}_{3}+\mathrm{OLE}$ & $\begin{array}{l}0.44 \mathrm{ALD} 2+0.64 \mathrm{CH}_{2} \mathrm{O}+0.25 \mathrm{HO}_{2}+0.29 \mathrm{XO}_{2}+ \\
0.37 \mathrm{CO}+0.9 \mathrm{RXPAR}+ \\
0.4 \mathrm{OH}\end{array}$ & $\begin{array}{l}\text { Average of : } \\
8.5 \mathrm{E}-16^{*} \exp (-1520 / \mathrm{T}) \\
1.4 \mathrm{E}-15^{*} \exp (-2100 / \mathrm{T}) \\
1.0 \mathrm{E}-17\end{array}$ & $\begin{array}{l}{[3]} \\
{[3]} \\
{[3]}\end{array}$ \\
\hline $\mathrm{NO}_{3}+\mathrm{OLE}$ & $\begin{array}{l}0.91 \mathrm{XO}_{2}+\mathrm{CH}_{2} \mathrm{O}+0.09 \mathrm{XO}_{2} \mathrm{~N}+\mathrm{NO}_{2}+\mathrm{ALD} 2 \\
+\mathrm{RXPAR}\end{array}$ & $\begin{array}{l}\text { Average of : } \\
4.0 \mathrm{E}-14^{*} \exp (-400 / \mathrm{T}) \\
6.0 \mathrm{E}-16 \\
3.5 \mathrm{E}-15\end{array}$ & $\begin{array}{l}{[3]} \\
{[3]} \\
{[3]}\end{array}$ \\
\hline $\mathrm{OH}+\mathrm{C}_{2} \mathrm{H}_{4}(+\mathrm{M})$ & $\mathrm{HO}_{2}+1.56 \mathrm{CH}_{2} \mathrm{O}+0.22 \mathrm{ALD} 2+\mathrm{XO}_{2}$ & $\begin{array}{l}\mathrm{K}_{0}=1.0 \mathrm{E}-28^{*}(300 / \mathrm{T})^{4.5} \\
\mathrm{~K}_{\infty}=8.8 \mathrm{E}-12^{*}(300 / \mathrm{T})^{0.85}\end{array}$ & \\
\hline $\mathrm{O}_{3}+\mathrm{C}_{2} \mathrm{H}_{4}$ & $\mathrm{CH}_{2} \mathrm{O}+0.26 \mathrm{HO}_{2}+0.12 \mathrm{OH}+0.43 \mathrm{CO}$ & $1.2 \mathrm{E}-14 * \exp (-2630 / \mathrm{T})$ & {$[1]$} \\
\hline $\mathrm{OH}+\mathrm{CH}_{3} \mathrm{COCHO}$ & $\mathrm{XO}_{2}+\mathrm{C}_{2} \mathrm{O}_{3}$ & $1.5 \mathrm{E}-11$ & {$[3]$} \\
\hline $\mathrm{OH}+\mathrm{ISOP}$ & $\begin{array}{l}0.85 \mathrm{XO}_{2}+0.61 \mathrm{CH}_{2} \mathrm{O}+0.58 \mathrm{OLE}+ \\
0.85 \mathrm{HO}_{2}+0.15 \mathrm{XO}_{2} \mathrm{~N}+ \\
0.03 \mathrm{CH}_{3} \mathrm{COCHO}+0.63 \mathrm{PAR}\end{array}$ & $2.7 \mathrm{E}-11 * \exp (390 / \mathrm{T})$ & {$[3]$} \\
\hline $\mathrm{O}_{3}+\mathrm{ISOP}$ & $\begin{array}{l}0.9 \mathrm{CH}_{2} \mathrm{O}+0.55 \mathrm{OLE}+0.36 \mathrm{CO}+ \\
0.15 \mathrm{C}_{2} \mathrm{O}_{3}+0.63 \mathrm{PAR}+0.3 \mathrm{HO}_{2}+0.18 \mathrm{XO}_{2}+ \\
0.03 \mathrm{CH}_{3} \mathrm{COCHO}+0.28 \mathrm{OH}\end{array}$ & $1.04 \mathrm{E}-14 * \exp (-1995 / \mathrm{T})$ & {$[3]$} \\
\hline $\mathrm{NO}_{3}+\mathrm{ISOP}$ & $\begin{array}{l}0.9 \mathrm{HO}_{2}+0.9 \text { ORGNTR }+0.45 \mathrm{OLE}+0.12 \\
\mathrm{ALD} 2+0.08 \mathrm{CH}_{3} \mathrm{COCHO}+0.1 \mathrm{NO}_{2}+0.03 \\
\mathrm{CH}_{2} \mathrm{O}\end{array}$ & $3.15 \mathrm{E}-12 * \exp (-450 / \mathrm{T})$ & {$[3]$} \\
\hline $\begin{array}{l}\mathrm{NO}+\mathrm{XO}_{2} \\
\mathrm{XO}_{2}+\mathrm{XO}_{2}\end{array}$ & $\mathrm{NO}_{2}$ & $\begin{array}{l}2.6 \mathrm{E}-12^{*} \exp (365 / \mathrm{T}) \\
6.8 \mathrm{E}-14^{[\mathrm{KC} 81]}\end{array}$ & $\begin{array}{l}{[2]} \\
{[2]} \\
{[3]}\end{array}$ \\
\hline $\mathrm{NO}+\mathrm{XO}_{2} \mathrm{~N}$ & ORGNTR & $2.6 \mathrm{E}-12 * \exp (365 / \mathrm{T})^{[\mathrm{KC} 79]}$ & {$[2]$} \\
\hline $\begin{array}{l}\mathrm{HO}_{2}+\mathrm{XO}_{2} \\
\mathrm{PAR}+\mathrm{RXPAR}\end{array}$ & $\mathrm{ROOH}$ & $\begin{array}{l}7.5 \mathrm{E}-13 * \exp (700 / \mathrm{T})^{[\mathrm{KC} 82]} \\
8 \mathrm{E}-11\end{array}$ & {$[2]$} \\
\hline $\mathrm{OH}+\mathrm{ORGNTR}$ & $\mathrm{NO}_{2}+\mathrm{XO}_{2}$ & $5.9 \mathrm{E}-13 * \exp (-360 / \mathrm{T})$ & {$[2]$} \\
\hline $\mathrm{HO}_{2}+\mathrm{XO}_{2} \mathrm{~N}$ & $\mathrm{ROOH}$ & $(\mathrm{KC} 81 * \mathrm{KC} 82) / \mathrm{KC} 79$ & {$[5]$} \\
\hline $\mathrm{DMS}+\mathrm{OH}$ & $\mathrm{SO}_{2}$ & $1.1 \mathrm{E}-11 * \exp (-240 / \mathrm{T})$ & {$[1]$} \\
\hline $\mathrm{DMS}+\mathrm{OH}$ & $0.75 \mathrm{SO}_{2}+0.25 \mathrm{MSA}$ & $\begin{array}{l}1.0 \mathrm{E}-39 * \exp (5820 / \mathrm{T}) \\
5.0 \mathrm{E}-30 * \exp (6280 / \mathrm{T})\end{array}$ & {$[1]$} \\
\hline $\mathrm{DMS}+\mathrm{NO}_{3}$ & $\mathrm{SO}_{2}$ & $1.9 \mathrm{E}-13 * \exp (520 / \mathrm{T})$ & {$[6]$} \\
\hline $\mathrm{OH}+\mathrm{SO}_{2}$ & $\mathrm{SO}_{4}^{2-}$ & $\begin{array}{l}\mathrm{K}_{0}=3.3 \mathrm{E}-31 *(300 / \mathrm{T})^{4.3} \\
\mathrm{~K}_{\infty}=1.6 \mathrm{E}-12 *(300 / \mathrm{T})\end{array}$ & {$[1]$} \\
\hline $\mathrm{OH}+\mathrm{NH}_{3}$ & $\mathrm{NH}_{2}$ & $1.7 \mathrm{E}-12 * \exp (-710 / \mathrm{T})$ & {$[1]$} \\
\hline $\mathrm{NO}+\mathrm{NH}_{2}$ & & $4.0 \mathrm{E}-12 * \exp (450 / \mathrm{T})$ & {$[1]$} \\
\hline $\mathrm{NO}_{2}+\mathrm{NH}_{2}$ & & $2.1 \mathrm{E}-12 * \exp (650 / \mathrm{T})$ & {$[1]$} \\
\hline $\mathrm{HO}_{2}+\mathrm{NH}_{2}$ & & $3.4 \mathrm{E}-11$ & {$[1]$} \\
\hline $\mathrm{O}_{2}+\mathrm{NH}_{2}$ & & $6.0 \mathrm{E}-21$ & [1] \\
\hline $\mathrm{O}_{3}+\mathrm{NH}_{2}$ & & $4.3 \mathrm{E}-12 * \exp (-930 / \mathrm{T})$ & [1] \\
\hline
\end{tabular}


average of the rates of the reactions of the $\mathrm{C} 2\left(\mathrm{CH}_{3} \mathrm{CH}_{2} \mathrm{O}_{2}\right)$ and $\mathrm{C} 3\left(\mathrm{CH}_{3} \mathrm{CH}_{2} \mathrm{CH}_{2} \mathrm{O}_{2}\right)$ peroxy radicals is adopted. For the reaction of $\mathrm{NO}+\mathrm{XO}_{2} \mathrm{~N}$ and $\mathrm{XO}_{2}+\mathrm{HO}_{2}$, oxidation of $\mathrm{ROOH}$ (higher organic peroxides), and oxidation of ORGNTR (alkyl nitrates) the values provided in Yarwood et al. (2005) are used. A detailed evaluation of these updates in reaction rates using chemical box model calculations has been presented by Williams and Van Noije (2008). Gaseous conversion of $\mathrm{N}_{2} \mathrm{O}_{5}$ with nitric acid $\left(\mathrm{HNO}_{3}\right)$ via the reaction with water vapour is not included, as it has been found to exhibit a rather negligible effect in the presence of the heterogeneous conversion on aqueous surfaces (Williams et al., 2009b), which is parameterized as described in Sect. 3.3. A comprehensive list of all reaction rates and the associated reaction data employed is provided in Table 3 .

\subsection{Photolysis}

For the calculation of photodissociation rates an offline parameterization for the derivation of actinic fluxes is used which is based on the work of Landgraf and Crutzen (1998) and expanded according to Krol and van Weele (1997) to account for the variations in actinic fluxes below, in and above clouds, variations caused by snow and ice surfaces with high albedo, and variations in the (largely stratospheric) overhead $\mathrm{O}_{3}$ column. The approach uses 7 absorption bands across the spectral range $202-752.5 \mathrm{~nm}$ as defined in Landgraf and Crutzen (1998).

Characteristic photodissociation rates for each photolytically active trace species are initially calculated for a model atmosphere which only accounts for the height-resolved absorption of photolysing light determined by the overhead $\mathrm{O}_{3}$ column above any respective model layer. The characteristic (temperature dependent) absorption coefficients and quantum yields for each of the respective trace species are then used to determine the individual photodissociation rates. These rates are then multiplied by the ratio of the actinic flux pre-calculated for a standard, cloud free scattering/absorbing atmosphere and an absorption-only atmosphere for a chosen spectral bin within each of the predefined absorption bands (see Landgraf and Crutzen (1998) for further details), and stored in a lookup table. The wavelength grid adopted for this purpose is that defined in Brühl and Crutzen (1988), which has highest resolution in the UV spectral region. The profiles used for the derivation of the actinic fluxes in the lookup table are based on the standard AFGL (Air Force Geophysics Laboratory, Anderson et al., 1986) atmosphere for the tropics, for 21 March, with surface albedo of 0.05 , and a total ozone column of 324 DU. Aerosol scattering is implicitly included in the lookup table and based on the Elterman (1968) standard aerosol profile with total optical depth of 0.38 at $320 \mathrm{~nm}$ and Ångström parameter of 1.4.

The pre-calculated actinic fluxes are indexed using the relevant temperature, pressure and optical depth at a particular model level when accounting for clouds, ozone and sur-
Table 4. The photolysis reactions included in the model. Only shown are the reaction products that are calculated explicitly by the chemical solver. Additional details: [1] The quantum yield for the production of $\mathrm{O}\left({ }^{1} \mathrm{D}\right)$ from the photolysis of $\mathrm{O}_{3}$ is taken from Shetter et al. (1996); [2] For the photolysis rate of ORGNTR, absorption cross section values for a $\mathrm{C} 4$ mono-nitrate are used (Roberts and Fayer, 1989); [3] $\mathrm{J}\left(\mathrm{CH}_{3} \mathrm{C}(\mathrm{O}) \mathrm{CHO}\right)=5.5^{*} \mathrm{~J}\left(\mathrm{CH}_{2} \mathrm{O} \rightarrow \mathrm{CO}+\right.$ $2 \mathrm{HO}_{2}$ ); [4] The photolysis rate for $\mathrm{ROOH}$ is set equal to that of $\mathrm{CH}_{3} \mathrm{OOH}$ due to the lack of data regarding the characteristic absorption parameters. Those photolysis rates which are temperature independent are shown in blue.

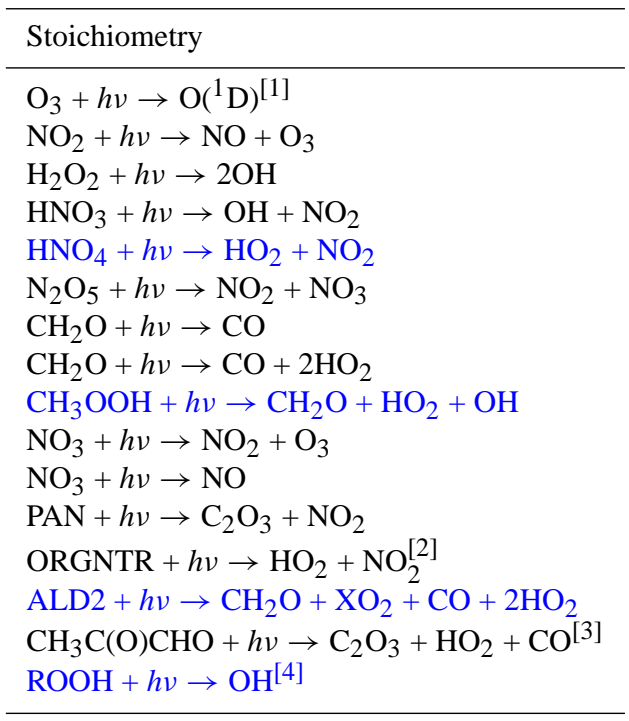

face albedo following Krol and van Weele (1997). Although heavily parameterized, this method avoids the radiative transfer calculation of the actinic flux for each of the 140 spectral bins included on the wavelength grid, which is expensive in a 3-D global chemistry transport model. For the calculation of the optical depth of clouds we use the cloud liquid water content taken from the ECMWF meteorological data and assume an effective radius of $8 \mu \mathrm{m}$ for all cloud droplets. For cirrus particles we use the associated ice water content, where the particle shape is assumed to be hexagonal. A maximum overlap type scaling method is then used to determine the effective optical depth introduced throughout the atmospheric column. Here the optical depth at each model level is scaled with the maximal cloud cover in the column. In total 16 photolysis rates are included in the scheme (see Table 4).

\subsection{Heterogeneous and aqueous phase reactions}

For the loss of gaseous trace species via heterogeneous oxidation processes, the model explicitly accounts for the oxidation of $\mathrm{SO}_{2}$ in cloud and aerosol through aqueous phase reactions with $\mathrm{H}_{2} \mathrm{O}_{2}$ and $\mathrm{O}_{3}$, depending on the acidity of the solution. Moreover, the heterogeneous conversion of $\mathrm{N}_{2} \mathrm{O}_{5}$ into $\mathrm{HNO}_{3}$ on the available surface area of cloud droplets, cirrus 
particles and hydrated sulphate aerosols has been shown to be an important inclusion in global models (Dentener and Crutzen, 1993). For this process the reactive surface area density (SAD) that is available from each of the different particle types is needed, and calculated as follows. For cloud droplets, the number of droplets per unit volume is calculated using the liquid water content provided in the ECMWF meteorological data when assuming an effective radius of $8 \mu \mathrm{m}$ for all cloud droplets. The SAD that is available is then calculated assuming a spherical shape for each droplet. For cirrus particles the effective radius is calculated using the parameterization of $\mathrm{Fu}$ (1996). The relationship derived by Heymsfield and McFarquhar (1996) for the calculation of the crosssectional area of the ice particles is adopted, which is subsequently scaled to SAD using a factor of 10 , as suggested in Schmitt and Heymsfield (2005), thought to be representative of irregularly shaped particles. The reaction probability ( $\gamma$ value) is set equal to 0.01 for the conversion on ice surfaces. For the conversion on hydrated sulphate particles the approach of Dentener and Crutzen (1993) is employed using a global mean $\gamma$ value of 0.02 , as suggested by Evans and Jacob (2005).

\subsection{The chemical solver}

The chemical solver used in TM5 is the Euler Backward Iterative (EBI) solver (Hertel et al., 1996), which has been specifically designed for use with the CBM4 mechanism of Gery et al. (1989). This has been shown to have the best overall performance when applied in large-scale atmospheric models which incorporate operator splitting (Huang and Chang, 2001). The chemical time step employed is typically $15 \mathrm{~min}$, where the emission of NO and dry deposition terms are included during the solution of the differential equations to avoid numerical artifacts. The number of iterations applied for each chemical species in order to achieve a converged solution of the differential equations varies depending on the atmospheric lifetime of each particular species and is larger in the boundary layer, where the perturbations due to emissions can be large. For some circumstances, where fast chemical processes dominate (i.e. in high $\mathrm{NO}_{\mathrm{x}}$ environments), a mass balance step is applied to the gas phase components of $\mathrm{NO}_{\mathrm{y}}$, where $\mathrm{NO}_{\mathrm{y}}$ is defined as the sum of $\mathrm{NO}, \mathrm{NO}_{2}, \mathrm{NO}_{3}, \mathrm{HNO}_{3}, \mathrm{HNO}_{4}, 2 \times \mathrm{N}_{2} \mathrm{O}_{5}, \mathrm{PAN}$, ORGNTR and $\mathrm{NO}_{3}^{-}$, to ensure no artificial loss of nitrogen occurs.

\subsection{Aerosol processes}

Gas-aerosol partitioning, including the amount of water and acidity associated with atmospheric particles, is calculated using the Equilibrium Simplified Aerosol Model (EQSAM, Metzger et al., 2002). Depending on a classification of the local aerosol conditions a solution of the chemical equilibrium is calculated involving $\mathrm{HNO}_{3}, \mathrm{NH}_{3}, \mathrm{NH}_{4}^{+}$and the ni- trate aerosol $\mathrm{NO}_{3}^{-}$. Due to its very low vapour pressure $\mathrm{SO}_{4}^{2-}$ is assumed to remain completely in the aerosol phase. The water content in the aerosol phase is also evaluated. EQSAM has also been coupled to the aerosol microphysics scheme M7, which describes sulphate, black carbon, organic carbon, sea salt and mineral dust in seven soluble or insoluble size modes (Vignati et al., 2004), although M7 is not applied for the evaluation presented in this paper. For more details the reader is referred to Aan den Brugh et al. (2010).

\subsection{Stratospheric boundary conditions}

The modified CBM4 chemical mechanism does not include either halogenated species or photolytic destruction below $202 \mathrm{~nm}$, and is therefore not adequate for the description of stratospheric chemical processes. Thus realistic upper boundary conditions for the longer-lived gases such as $\mathrm{O}_{3}$, $\mathrm{CH}_{4}$, and $\mathrm{HNO}_{3}$ must be provided in order to capture the influence of stratospheric intrusions on the composition of the upper troposphere. The total overhead ozone column is constrained with monthly mean values observed by Earthorbiting satellites, where the stratospheric ozone field is relaxed to the ozone sonde-based climatological ozone profile of Fortuin and Kelder (1998). For the total column observations the assimilated fields from a multi-sensor reanalysis dataset for the time period 1979 to present day are used (Van der A et al., 2010), which is based on the different available ozone-measuring satellite instruments over this period. In the tropics $\left(30^{\circ} \mathrm{S}-30^{\circ} \mathrm{N}\right)$ stratospheric ozone is nudged for pressures $<45 \mathrm{hPa}$, whereas in the extra-tropics ozone is nudged for pressures $<90 \mathrm{hPa}$ to account for differences in the height of the tropopause. The relaxation times applied are 2.5 and 4 days for the tropics and extra-tropics respectively. The magnitude of stratosphere-troposphere exchange depends on the strength of the overturning circulation, which has been shown to be different for the different ECMWF reanalyses (e.g. ERA-40, ERA-Interim) and operational data sets (e.g. Van Noije et al., 2004, 2006b; Monge-Sanz et al., 2007). This affects the tropospheric $\mathrm{O}_{3}$ budget and chemistry of the upper troposphere significantly. The altitudes at which nudging is applied has been optimized to minimize the effects of biases in the overturning circulations on the influx of $\mathrm{O}_{3}$ from the lower stratosphere (Van Noije et al., 2004).

For $\mathrm{HNO}_{3}$ a stratospheric climatology based on the UARS MLS satellite observations is applied by prescribing the ratio of $\mathrm{HNO}_{3} / \mathrm{O}_{3}$ at $10 \mathrm{hPa}$. Methane in the stratosphere is nudged to the HALOE-based climatology of Grooss and Russell (2005) with the same time scale and above the same pressure levels as used for stratospheric $\mathrm{O}_{3}$. This constraint implicitly accounts for the stratospheric chemical loss of $\mathrm{CH}_{4}$ by $\mathrm{OH}, \mathrm{Cl}$ and $\mathrm{O}\left({ }^{1} \mathrm{D}\right)$. 
Table 5. Details concerning the chemical data used for the calculation of heterogeneous scavenging rates, where $\Delta_{s o l n} H$ is the enthalpy of solution, $k_{H}^{\theta}$ is the Henry's law coefficient at $298.15 \mathrm{~K}$ and $R$ the gas constant. For the species containing a-CHO functional group (denoted by *) a hydration rate is also applied which further enhances the solubility in aqueous solution. For ALD2 an average is calculated from the uptake values for $\mathrm{CH}_{3} \mathrm{CHO}$ and $\mathrm{C}_{2} \mathrm{H}_{5} \mathrm{CHO}$, whereas for $\mathrm{ROOH}$ the uptake value for $\mathrm{C}_{2} \mathrm{H}_{5} \mathrm{OOH}$ is adopted. For the species exhibiting high solubility $\left(\mathrm{HNO}_{3}, \mathrm{SO}_{4}^{2-}, \mathrm{NH}_{4}^{+}, \mathrm{MSA}\right)$ irreversible scavenging is included.

\begin{tabular}{lccl}
\hline Trace species & $k_{H}^{\theta}[\mathrm{M} / \mathrm{atm}]$ & $\frac{\Delta_{\text {soln }} H}{R}$ & Reference \\
\hline $\mathrm{SO}_{2}$ & 1.2 & 3100 & Sillén and Martell (1964) \\
$\mathrm{NH}_{3}$ & 75 & 3400 & Hales and Drewes (1979) \\
$\mathrm{H}_{2} \mathrm{O}_{2}$ & $1 \times 10^{5}$ & 6300 & Lind and Kok (1994) \\
$\mathrm{CH}_{3} \mathrm{OOH}$ & 310 & 5300 & O'Sullivan et al. (1996) \\
$\mathrm{ROOH}^{\mathrm{CH}} \mathrm{O}^{*}$ & 340 & 6000 & O'Sullivan et al. (1996) \\
$\mathrm{CH}_{3} \mathrm{C}(\mathrm{O}) \mathrm{CHO}^{*}$ & $3.2 \times 10^{4}$ & 7200 & Betterton and Hoffmann (1988) \\
$\mathrm{ALD}^{*}$ & 17 & 5000 & Zhou and Mopper (1990) \\
& 13 & 5700 & Zhou and Mopper (1990) \\
ORGNTR & 1 & 6000 & Estimated \\
\hline
\end{tabular}

\section{Deposition and emissions}

\subsection{Wet deposition}

Wet deposition considers both in-cloud and below-cloud scavenging of gases and aerosol by liquid and ice precipitation. Furthermore, consistent with the parent ECMWF model, the model makes a distinction between scavenging due to large-scale and convective precipitation, according to Guelle et al. (1998), Jeuken et al. (2001), and Roelofs and Lelieveld (1995).

In-cloud scavenging in stratiform precipitation makes use of the altitude dependent precipitation formation rate, describing the conversion of cloud water into rainwater. We assume that a constant fraction of $30 \%$ of aerosol mass $\left(\mathrm{SO}_{4}^{2-}\right.$, $\mathrm{NO}_{3}^{-}$, MSA, and $\mathrm{NH}_{4}^{+}$) does not activate into cloud droplets, and will thus not be removed by precipitation. The fraction of gases removed by precipitation depends on Henry's law and dissociation (if applicable), temperature and liquid water content. For those species which hydrolyse in water (e.g. formaldehyde, $\mathrm{CH}_{2} \mathrm{O}$ ) the effective coefficients based on Henry's law are used, which account for enhanced dissolution adopting a constant $\mathrm{pH}=5$. The thermodynamic data used to calculate the respective Henry's law uptake coefficients are listed in Table 5, where the values have been selected from the compilation of Sander (1999). Scavenging of gases on ice surfaces is scaled by 0.2 relative to that by droplets.

In-cloud scavenging in stratiform precipitation makes use of the altitude dependent precipitation formation rate, describing the conversion of cloud water into rainwater. The uptake of gases is again described by Henry's law solubility, whereas for aerosol the scavenging efficiency was calculated from a collection kernel assuming a lognormal aerosol distribution (dry particle geometric mean radius of $0.034 \mu \mathrm{m}$ and geometric standard deviation 2.0). To account for subgrid processes and resolution dependencies, the stratiform inand below-cloud scavenging of gases and aerosols are solved assuming that the grid-box fractions that reside in, below, and outside clouds remain separated on a time scale of $3 \mathrm{~h}$, which is a typical time scale associated with the passage of a frontal system (Vignati et al., 2010). Convective scavenging of gases and aerosol is coupled to the parameterization of air mass fluxes in convective updrafts. The scavenging efficiencies for convective precipitation are calculated based on Henry's law coefficients using a standard temperature and an assumed liquid water content of $1 \mathrm{~g} / \mathrm{m}^{3}$. Highly soluble gases and aerosol are thus assumed to be completely scavenged in the vigorous convective updrafts producing rainfall rates of $>1 \mathrm{~mm} / \mathrm{h}$, and exponentially scaled down for lower rainfall rates. No additional below-cloud scavenging for convective rain was applied, since this is implicitly included in the convective updrafts.

\subsection{Dry deposition}

The dry deposition scheme is calculated online, based on a series of surface and atmospheric resistances on a $1^{\circ} \times 1^{\circ}$ spatial resolution, following the approach of Wesely (1989) as implemented by Ganzeveld and Lelieveld (1995). The scheme includes a parameterization for the trace gases as given in Table 6, using 3-hourly meteorological and surface parameters (see also Table 1). The scheme has been extended to account for sulphur dioxide and sulphate deposition velocities (Ganzeveld et al., 1998). The aerodynamic resistance is calculated from the model boundary layer stability, wind speed and surface roughness, where a quasi-laminar boundary layer resistance is incorporated. At the surface the model makes a distinction between uptake resistances 
Table 6. Selected soil, water, snow/ice and mesophyl resistances according to Ganzeveld and Lelieveld (1995) and Ganzeveld et al. (1998), in $\mathrm{s} \mathrm{m}^{-1}$. The cuticle resistance is $10^{5} \mathrm{~s} \mathrm{~m}^{-1}$, for all trace gases except for $\mathrm{HNO}_{3}$ and $\mathrm{N}_{2} \mathrm{O}_{5}$, where a value of $1 \mathrm{~s} \mathrm{~m}^{-1}$ is adopted.

\begin{tabular}{|c|c|c|c|c|}
\hline Trace gas & $r_{\text {soil }}$ & $r_{\text {wat }}$ & $r_{\text {snow } / \text { ice }}$ & $r_{\text {mes }}$ \\
\hline $\mathrm{O}_{3}$ & 400 & 2000 & 2000 & 1 \\
\hline $\mathrm{CO}$ & 5000 & $10^{5}$ & $10^{5}$ & 5000 \\
\hline NO & $10^{5}$ & $10^{5}$ & $10^{5}$ & 500 \\
\hline $\mathrm{NO}_{2} / \mathrm{NO}_{3}$ & 600 & 3000 & 3000 & 1 \\
\hline $\mathrm{HNO}_{3} / \mathrm{N}_{2} \mathrm{O}_{5}$ & 1 & 1 & 1 & 1 \\
\hline $\mathrm{H}_{2} \mathrm{O}_{2}$ & 80 & 72 & 80 & 1 \\
\hline $\mathrm{SO}_{2}$ & 100 & 1 & 1 & 1 \\
\hline PAN/ORGNTR & 3994 & 295 & 3394 & 1 \\
\hline ALD2 & $10^{5}$ & 300 & $10^{5}$ & 200 \\
\hline $\mathrm{CH}_{2} \mathrm{O} / \mathrm{CH}_{3} \mathrm{COCHO}$ & 1666 & 254 & 1666 & 1 \\
\hline $\mathrm{CH}_{3} \mathrm{OOH} / \mathrm{ROOH}$ & 3650 & 293 & 3650 & 1 \\
\hline $\mathrm{NH}_{3}$ & 100 & 1 & $10^{5}$ & 1 \\
\hline
\end{tabular}

for vegetation, soil, water, snow and ice (cf. Table 6). The vegetation resistance is calculated using the in-canopy aerodynamic, soil, and leaf resistance. The stomatal resistance is calculated online, depending on e.g. the soil wetness at the uppermost surface layer, where together with the cuticle and mesophyl resistances this is combined into the leaf resistance. The resulting deposition velocities show both a seasonal and diurnal cycle due to varying surface characteristics.

\subsection{Emissions}

Yearly totals for anthropogenic, biogenic and biomass burning emissions originate from a variety of inventories which are listed in Table 7. Most of the emission data are provided on a spatial resolution of $0.5^{\circ} \times 0.5^{\circ}$ with a monthly time resolution. The different types of emissions are applied separately in the model, for example to be able to distinguish between different emission heights.

Present-day anthropogenic emissions are based on the inventory from the RETRO project (Schultz et al., 2007) for the year 2000, while East-Asian anthropogenic emissions are replaced by the REAS inventory (Ohara et al., 2007).

International shipping emissions are from the AMVER inventory (Endresen et al., 2003), as provided to RETRO, but the $\mathrm{NO}_{\mathrm{x}}$ shipping emissions have been scaled up by a factor 1.95 to $6.3 \mathrm{Tg} \mathrm{N} \mathrm{yr}^{-1}$ in line with the findings of Corbett and Koehler (2003). A monthly varying 3-D field of $\mathrm{NO}_{\mathrm{x}}$ aircraft emissions $\left(0.7 \mathrm{Tg} \mathrm{N} \mathrm{yr}{ }^{-1}\right)$ is applied based on Schmitt and Brunner (1997) for the years 1992 and 2015, which were expanded for the period 1960 to 2020 by applying IPCC (1999) increase rates (Dameris et al., 2005). Emissions for the lumped CBM4 species are constructed from the
Table 7. Applied emission totals. References: [1] RETRO (Schultz et al., 2007); [2] REAS (Ohara et al., 2006); [3] ORCHIDEE (Lathière et al., 2006); [4] GEIA (Guenther et al. 2005); [5] GFED v2 (Van der Werf et al., 2006); [6] AMVER (Endresen et al., 2003); [7] AeroCom (Dentener et al., 2006b); [8] Bouwman et al. (1997); [9] Spiro et al. (1992); [10] Liss and Merlivat (1986).

\begin{tabular}{|c|c|c|c|}
\hline $\begin{array}{l}\text { Species } \\
\text { Tg yr }^{-1}\end{array}$ & Anthropogenic & Biogenic & $\begin{array}{l}\text { Biomass } \\
\text { burning }^{[5]}\end{array}$ \\
\hline $\begin{array}{l}\mathrm{CO} \\
\mathrm{Tg} \mathrm{CO} \mathrm{yr}^{-1}\end{array}$ & $592^{[1,2,6]}$ & $179^{[4]}$ & 391 \\
\hline $\begin{array}{l}\mathrm{NO}_{\mathrm{X}} \\
\mathrm{Tg} \mathrm{N} \mathrm{yr}\end{array}$ & $32.9^{[1,2,6]}$ & $9.3^{[3]}$ & 5.1 \\
\hline $\begin{array}{l}\mathrm{SO}_{2} \\
\mathrm{Tg} \mathrm{SO}_{2} \mathrm{yr}^{-1}\end{array}$ & $108^{[7]}$ & $29^{[7]}$ & 2.3 \\
\hline $\begin{array}{l}\text { Isoprene } \\
\mathrm{Tg} \mathrm{C}_{5} \mathrm{H}_{8} \mathrm{yr}^{-1}\end{array}$ & 0 & $565^{[3]}$ & 0 \\
\hline $\begin{array}{l}\mathrm{CH}_{2} \mathrm{O} \\
\mathrm{Tg} \mathrm{C} \mathrm{yr}^{-1}\end{array}$ & $0.46^{[1,2]}$ & $10.1^{[3]}$ & 0.12 \\
\hline $\begin{array}{l}\text { PAR } \\
\text { Tg C yr }\end{array}$ & $54.8^{[1,2]}$ & $162.8^{[3,4]}$ & 7.3 \\
\hline 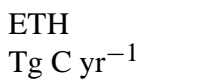 & $5.5^{[1,2]}$ & $3.9^{[3]}$ & 3.21 \\
\hline 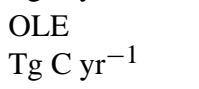 & $3.2^{[1,2]}$ & $0.86^{[4]}$ & 1.75 \\
\hline $\begin{array}{l}\text { ALD2 } \\
\operatorname{Tg~C~yr}^{-1}\end{array}$ & $0.96^{[1,2]}$ & $9.56^{[3]}$ & 0.55 \\
\hline $\begin{array}{l}\mathrm{CH}_{3} \mathrm{COCHO} \\
\mathrm{Tg} \mathrm{C} \mathrm{yr}^{-1}\end{array}$ & $3.5^{[1,2]}$ & 0 & 0.15 \\
\hline $\begin{array}{l}\mathrm{NH}_{3} \\
\mathrm{Tg} \mathrm{NH} \mathrm{yr}_{3}-1\end{array}$ & $45.5^{[8]}$ & $12.9^{[8]}$ & $9.6^{[8]}$ \\
\hline 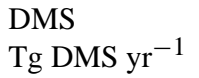 & 0 & $37.2^{[9,10]}$ & 0 \\
\hline
\end{tabular}

available NMVOC in the inventories according to the recommendations given in Yarwood et al. (2005).

To account for the variation in emission heights, anthropogenic emissions are injected in the lowest two model layers if the thickness of the first layer is less than $3.5 \mathrm{hPa}(\sim 30 \mathrm{~m})$. This is the case when the first model layer is equal to the one from the standard ECMWF 60 or 91 layer definitions. In current model simulation with 34 levels the anthropogenic emissions are introduced in the surface layer only.

For biogenic emissions climatological values are used as derived from GEIA (Global Emissions Inventory Activity, Guenther et al., 1995) or the 12-year average from the ORCHIDEE model (Lathière et al., 2006). A diurnal cycle for isoprene emissions is applied, with as functional form the cosine of the solar zenith angle during daytime, and zero emissions during nighttime. Terpene and other biogenic NMVOC emissions are not included.

$\mathrm{NO}_{\mathrm{x}}$ production from lightning is calculated using a linear relationship between lightning flashes and convective 
precipitation (Meijer et al., 2001). Marine lightning is assumed to be 10 times less active as lightning over land. The fraction of cloud-to-ground over total flashes is determined by a fourth-order polynomial function of the cold cloud thickness (Price and Rind, 1993). The $\mathrm{NO}_{\mathrm{x}}$ production for intra-cloud flashes is 10 times less than that for cloud-toground flashes, according to Price et al. (1997), who assume that intra-cloud flashes dissipate one tenth of the energy of cloud-to-ground flashes. The $\mathrm{NO}_{\mathrm{x}}$ production is calculated by adopting a scaling factor (Meijer et al., 2001), which leads to a total annual production for current model simulation of $5.9 \mathrm{Tg} \mathrm{N} \mathrm{yr}^{-1}$. This is in the range of $2-8 \mathrm{Tg} \mathrm{N} \mathrm{yr}^{-1}$ given in the literature (Schumann and Huntrieser, 2007). The production may vary depending on variations in the meteorology that drives the model.

Biomass burning emissions are taken from the Global Fire Emissions Database, version 2 (GFEDv2) 8-day emission inventory (Van der Werf et al., 2006). The biomass burning emissions are distributed over different altitude ranges, depending on the latitude. The emission heights are similar to those described in Dentener et al. (2006b), except that we increase the injection height in the tropics to $2 \mathrm{~km}$ based on the evidence from recent satellite observations (e.g. Labonne et al., 2007).

Methane emissions are not applied in the current version, given the long chemical lifetime of methane and the difficulty to keep the uncertain methane emission total in balance with the methane chemical loss by $\mathrm{OH}$. Instead, methane surface concentrations are prescribed according to zonal monthly fields which are consistent with the observations at background surface networks.

$\mathrm{NH}_{3}$ emissions are based on the inventory of Bouwman et al. (1997) and include biogenic emissions over land and oceans, and anthropogenic emissions from industry, land use, and fossil fuel and biomass burning. Anthropogenic and natural $\mathrm{SO}_{2}$ emissions are taken from the AeroCom project (Dentener et al., 2006b; and references therein). Anthropogenic and biomass burning $\mathrm{SO}_{2}$ emissions are added as $97.5 \%$ of $\mathrm{SO}_{2}$ and $2.5 \%$ of $\mathrm{SO}_{4}^{2-}$, to account for sub-grid scale sulphate formation. $\mathrm{SO}_{2}$ emissions from volcanoes are injected at higher elevations in the model. Land based emissions for DMS are applied according to Spiro et al. (1992). The ocean-air fluxes are calculated following the parameterization from Liss and Merlivat (1986), depending on wind speed, air temperature, and a climatological DMS concentration field in surface water.

\section{Model evaluation}

The seasonal cycles of tropospheric ozone and other important trace gases, namely $\mathrm{CO}, \mathrm{NO}_{2}, \mathrm{CH}_{2} \mathrm{O}$, and $\mathrm{OH}$, are evaluated by comparing tracer distributions against different sets of observations. Focus is placed on the observed large-scale variability in space (on a continental scale) and
Table 8. The tropospheric chemical production of $\mathrm{OH}$ given in $\mathrm{Tg} \mathrm{OH} \mathrm{yr}^{-1}$. The distribution for the $\mathrm{SH}$ extra-tropics/tropics/ $\mathrm{NH}$ extra-tropics are given in parentheses.

\begin{tabular}{ll}
\hline $\mathrm{O}\left({ }^{1} \mathrm{D}\right)+\mathrm{H}_{2} \mathrm{O}$ & $1578(110 / 1273 / 195)$ \\
$\mathrm{NO}+\mathrm{HO}_{2}$ & $956(66 / 691 / 199)$ \\
$\mathrm{O}_{3}+\mathrm{HO}_{2}$ & $392(41 / 265 / 86)$ \\
Remaining & $406(29 / 322 / 55)$ \\
Total gain & $3332(246 / 2551 / 535)$ \\
\hline
\end{tabular}

in time (on a seasonal scale). To distinguish between different latitudinal zones we define the extra-tropical Northern Hemisphere $\left(\mathrm{NH}, 30^{\circ} \mathrm{N}-90^{\circ} \mathrm{N}\right)$, the tropics $\left(30^{\circ} \mathrm{S}-30^{\circ} \mathrm{N}\right)$ and extra-tropical Southern Hemisphere ( $\mathrm{SH}, 30^{\circ} \mathrm{S}-90^{\circ} \mathrm{S}$ ). Figure 1 shows the different regions used in the evaluation, where species with short lifetimes (i.e. $\mathrm{NO}_{2}, \mathrm{CH}_{2} \mathrm{O}$ ) are evaluated over smaller regions.

The baseline simulation is performed for the year 2006 at a horizontal resolution of $3^{\circ} \times 2^{\circ}$ using 34 vertical layers, ranging from the surface up to $0.1 \mathrm{hPa}$. Meteorology from ECMWF operational forecasts drive the model. A spin-up of twice the year 2006 is applied to achieve chemical equilibrium before the actual simulation is performed. Diagnostics are similar as for the recent ACCENT model intercomparison project studies (e.g. Van Noije et al., 2006a; Shindell et al., 2006; Stevenson et al., 2006; and Dentener et al., 2006c) in order to allow a direct comparison of the performance of TM5-chem-v3.0 with other model versions and models.

\subsection{The hydroxyl radical $(\mathrm{OH})$}

Figure 2 shows the simulated zonal distribution of $\mathrm{OH}$ in the troposphere for both January and July 2006. The mass-weighted $\mathrm{OH}$ concentration is $\sim 10 \%$ lower compared to the climatological mean constructed by Spivakovsky et al. (2000), although the seasonal cycle agrees favorably (not shown). This results in a methane lifetime equal to $\sim 8.9 \mathrm{yr}$. This value is obtained by dividing the global mean burden of methane (4826 Tg) by the sum of the methane loss due to $\mathrm{OH}$ oxidation in the troposphere $\left(475 \mathrm{Tg} \mathrm{yr}^{-1}\right)$ and losses due to soil oxidation and by methane oxidation in the stratosphere ( $70 \mathrm{Tg} \mathrm{yr}^{-1}$; Prather et al., 2001). This value is slightly higher than the ensemble mean of $8.45 \pm 0.38 \mathrm{yr}$ given in Stevenson et al. (2006), and also higher than the TM5 results presented there $(\sim 7.9 \mathrm{yr})$. The increase in lifetime is in line with the increase in the fraction of $\mathrm{OH}$ scavenged by $\mathrm{CO}$ when using the most recent reaction and emission data (Williams and Van Noije, 2008).

An analysis of methyl chloroform (MCF) decay over the years 2000-2007 shows a very good correspondence to observations using the current modeled $\mathrm{OH}$ field (see Appendix A), where the MCF lifetime is $\sim 5.86 \mathrm{yr}$. Very similar MCF concentrations were modeled in a run where the 


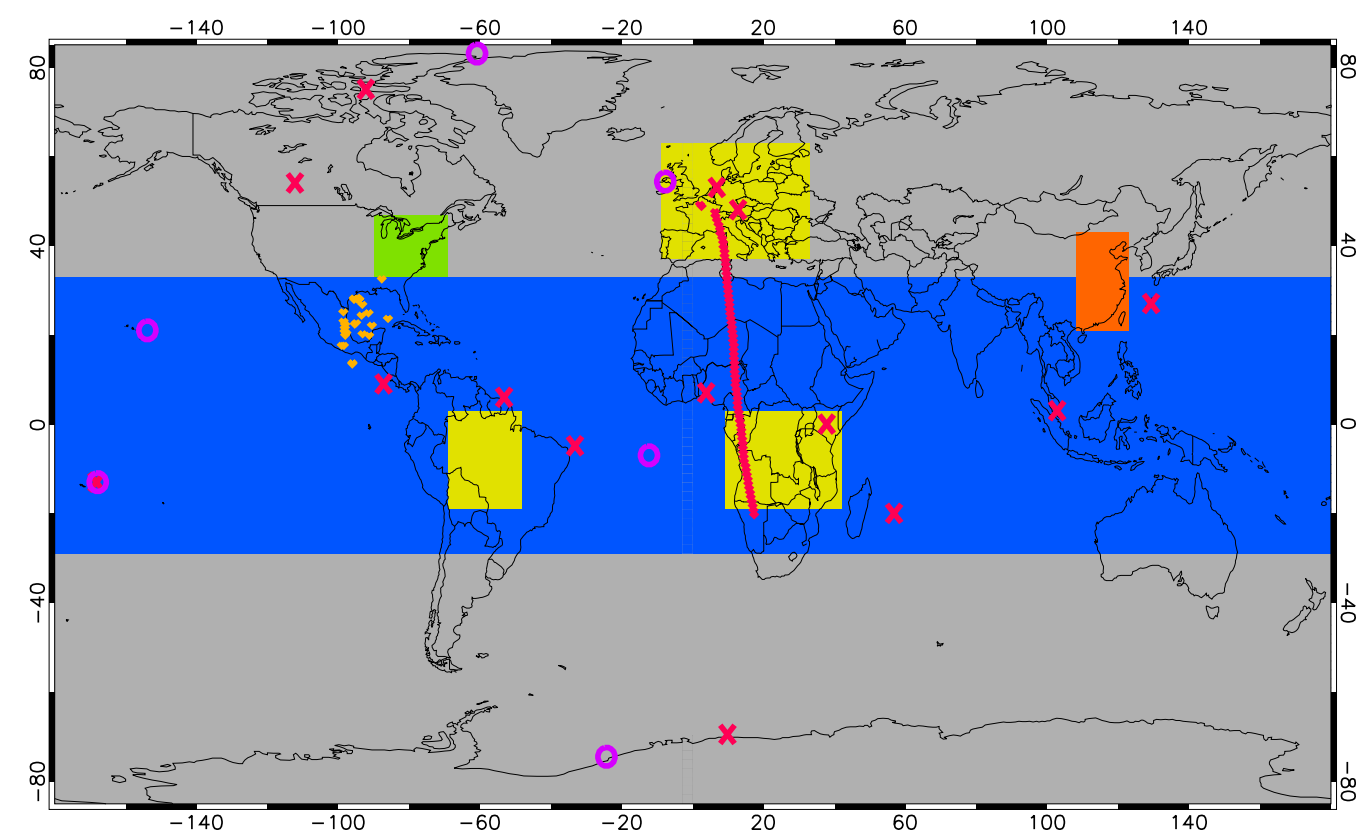

Fig. 1. The various regions, stations and flight locations used in the evaluation. The definition of these regions is as follows: tropics $\left(30^{\circ} \mathrm{S}-30^{\circ} \mathrm{N}\right)$, Eastern United States $\left(90^{\circ} \mathrm{W}-71^{\circ} \mathrm{W} \times 31^{\circ} \mathrm{N}-43^{\circ} \mathrm{N}\right)$, Europe $\left(10^{\circ} \mathrm{W}-30^{\circ} \mathrm{E} \times 35^{\circ} \mathrm{N}-60^{\circ} \mathrm{N}\right)$, Eastern China $\left(108^{\circ} \mathrm{W}-\right.$ $\left.120^{\circ} \mathrm{W} \times 20^{\circ} \mathrm{N}-40^{\circ} \mathrm{N}\right)$, Central Africa $\left(10^{\circ} \mathrm{E}-40^{\circ} \mathrm{E} \times 20^{\circ} \mathrm{S}-0^{\circ} \mathrm{N}\right)$, South America $\left(70^{\circ} \mathrm{W}-50^{\circ} \mathrm{W} \times 20^{\circ} \mathrm{S}-0^{\circ} \mathrm{N}\right)$. The pink circles indicate the GMD stations used for the evaluation of surface $\mathrm{O}_{3}$ and $\mathrm{CO}$, and the red crosses indicate the WOUDC stations used for the evaluation of $\mathrm{O}_{3}$ profiles. The red line denotes the flight path of the aircraft used for the comparison against MOZAIC data. Yellow dots indicate the ascents and descents from the INTEX-B campaign used in the $\mathrm{NO}_{2}$ evaluation.
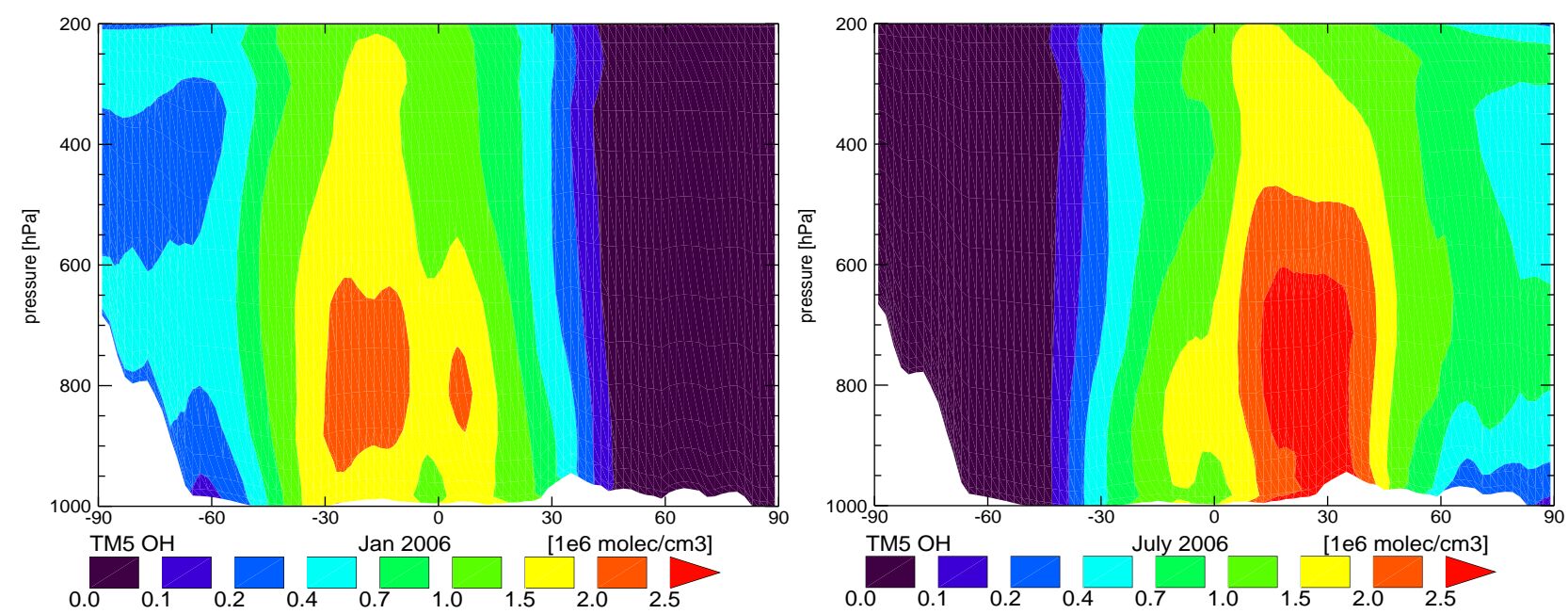

Fig. 2. Zonal monthly mean OH concentrations for January and July 2006 as simulated by the TM5 model.

Spivakovsky $\mathrm{OH}$ field was optimized, resulting in a scaling factor of 0.92 and a MCF lifetime of $5.76 \mathrm{yr}$, i.e. $\sim 2 \%$ lower than in the current TM5 simulation.

The tropospheric $\mathrm{OH}$ production budget is given in Table 8, with a primary $\mathrm{OH}$ formation due to $\mathrm{O}_{3}$ photolysis of $1578 \mathrm{Tg}$ per year, dominated by the tropics and with a somewhat larger contribution from the $\mathrm{NH}$ extra-tropics than from the SH extra-tropics related to the hemispheric asymmetry in tropospheric ozone burden and $\mathrm{NO}_{\mathrm{x}}$ emissions. The radical recycling terms ( $\mathrm{NO}+\mathrm{HO}_{2}$ and $\mathrm{O}_{3}+\mathrm{HO}_{2}$, respectively) contribute by another $1348 \mathrm{Tg}$ per year, of which $285 \mathrm{Tg}$ per year in the $\mathrm{NH}$ extra-tropics vs. $107 \mathrm{Tg}$ in the $\mathrm{SH}$ extra-tropics. The smaller primary and recycling terms add another $406 \mathrm{Tg}$. The total global $\mathrm{OH}$ production amounts to $3332 \mathrm{Tg}$ per year. The $\mathrm{OH}$ loss budget is dominated by the oxidation of $\mathrm{CO}$ (38\%) and $\mathrm{CH}_{4}$ (15\%), with the remaining 47\% through reaction with many other minor trace gases. 

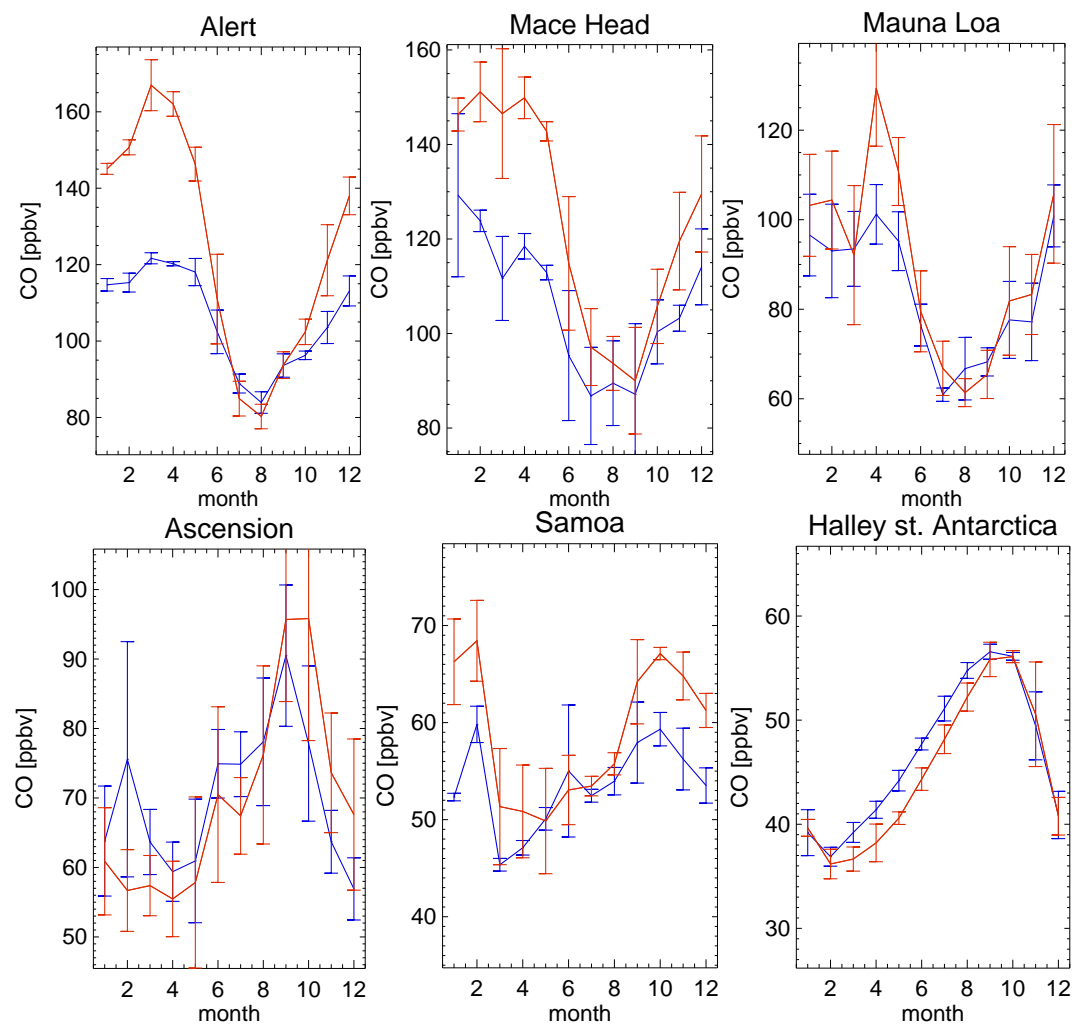

Fig. 3. Monthly mean comparison of TM5 surface CO (blue) against GMD surface observations (red) using co-located model output for 2006, sampled at the measurement times. The error bars indicate the standard deviation in the monthly means.

Table 9. The global CO budget for the year 2006 given in $\mathrm{Tg} \mathrm{CO} \mathrm{yr}-1$. The distribution for the SH extra-tropics/tropics/NH extra-tropics are given in parentheses. The stratospheric region is here defined as all levels where monthly mean $\mathrm{O}_{3}>150$ ppbv. The difference in total gain and loss implies a net trend in $\mathrm{CO}$ of $\sim 5 \mathrm{Tg}$.

\begin{tabular}{llll}
\hline Emissions & $1159(29 / 770 / 360)$ & Deposition & $184(6 / 105 / 73)$ \\
Trop. chem. production & $1169(74 / 917 / 177)$ & Trop. chem. loss & $2120(173 / 1587 / 360)$ \\
Strat. chem. production & $15(4 / 7 / 4)$ & Strat. chem. loss & $44(12 / 15 / 17)$ \\
Total gain & $2343(107 / 1694 / 541)$ & Total loss & $2348(191 / 1707 / 450)$ \\
Total burden & $353(59 / 188 / 106)$ & Lifetime (days) & 55 \\
\hline
\end{tabular}

\subsection{Carbon monoxide (CO)}

An analysis of the chemical $\mathrm{CO}$ budget is given in Table 9. The global and annual mean burden of CO in TM5 is $353 \mathrm{Tg}$, which which corresponds to an average concentration of $85.4 \mathrm{ppbv}$, based on the broad MOPITT $500 \mathrm{hPa}$ retrieval level. This is $22 \%$ higher than the value for TM5 presented in Shindell et al. (2006). This is consistent with the decrease in $\mathrm{OH}$ as well as increase in $\mathrm{CO}$ emissions in this model version, compared to the earlier version. Approximately $50 \%$ of the $\mathrm{CO}$ gain is due to direct emissions, with the other $50 \%$ being due to both the oxidation of methane and NMVOC.

Figure 3 shows the TM5 surface concentrations as compared to a selection of ground-based observations from the
NOAA Earth System Research Laboratory (ESRL) Global Monitoring Division (GMD). An extended evaluation against additional GMD stations is given in the supplementary material. In Figs. 4 and 5 we compare modeled CO concentrations, where the MOPITT averaging kernels are applied, against MOPITT Version 4 Level 2 data at $500 \mathrm{hPa}$ (Deeter et al., 2010).

$\mathrm{CO}$ is underestimated at the Alert and Mace Head GMD stations during the spring (March-April-May, MAM) season by $\sim 20-40 \mathrm{ppbv}$. Also compared to MOPITT a negative bias is found over the NH in April of the order of $\sim 30$ ppbv. In summer (June-July-August, JJA) the model bias is reduced to $<5$ ppbv. At Halley Station (Antarctica) the model shows a small positive bias of $\sim 5 \mathrm{ppbv}$ in the local winter season. 

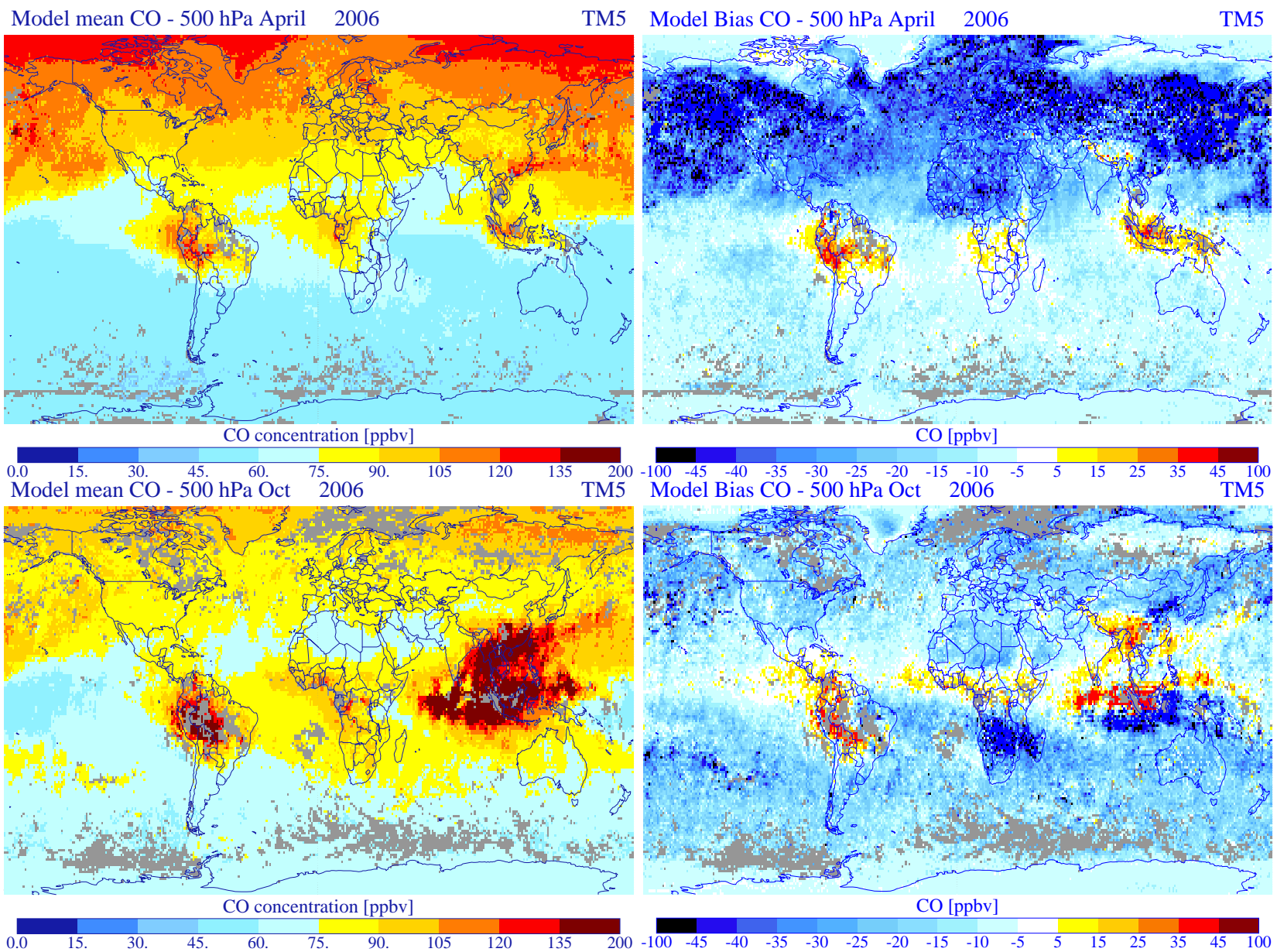

Fig. 4. Mean and bias of TM5 to MOPITT-V4 at $500 \mathrm{hPa}$ for April and October 2006, using the same color coding as shown in Shindell et al. (2006). Positive numbers in the bias plots indicate a model overestimate.
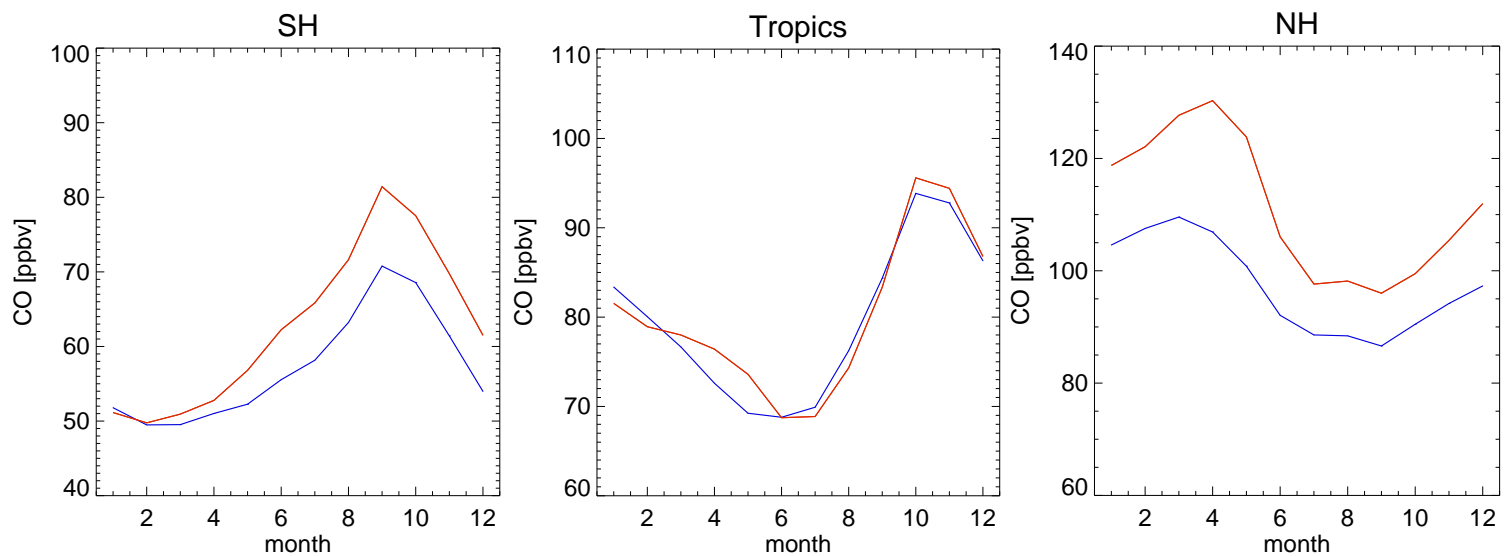

Fig. 5. The annual cycle of mean, mass weighted CO in observations (red) and in TM5 (blue) for the MOPITT 500-hPa retrieval level.

Also at other GMD stations in the SH the model corresponds to within 5 ppbv, see supplementary material. Against MOPITT a small negative bias of the order of $\sim 10 \mathrm{ppbv}$ is found for October.
At Ascension Island in the tropics both positive and negative biases are observed depending on the season, while generally good agreement is achieved at Mauna Loa. For tropical background regions, the model shows a small negative bias 

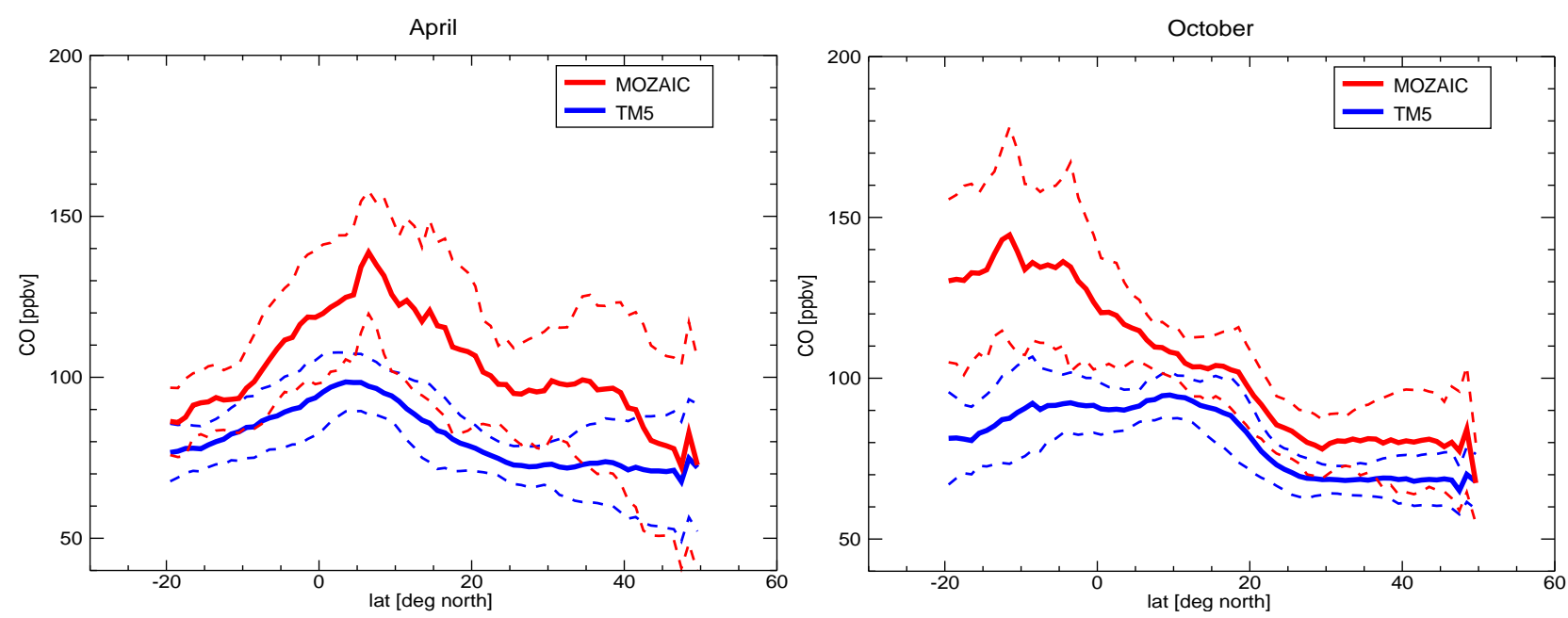

Fig. 6. Monthly mean comparisons of TM5 UTLS CO concentrations sampled at the measurement place and time against MOZAIC flight data between Frankfurt $\left(50.0^{\circ} \mathrm{N}, 8.6^{\circ} \mathrm{E}\right)$ and Windhoek $\left(17.7^{\circ} \mathrm{E}, 22.5^{\circ} \mathrm{S}\right)$ for April and October 2006. Dashed lines indicate the standard deviation in the monthly means. Data at pressures higher than $300 \mathrm{hPa}$ has been filtered out.
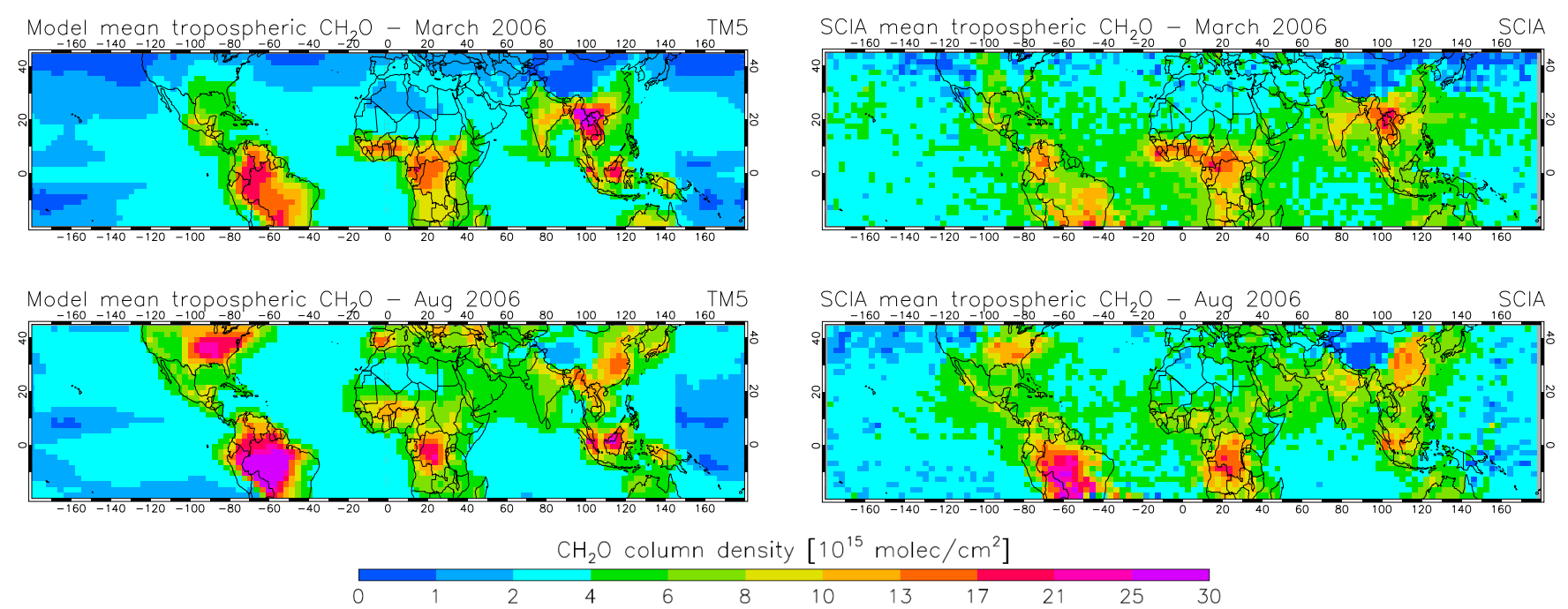

Fig. 7. TM5 true monthly average tropospheric $\mathrm{CH}_{2} \mathrm{O}$ column density in March and August 2006 vs. SCIAMACHY total columns retrieval.

of $\sim 5$ ppbv against MOPITT, with positive biases in various regions close to emission regions, both in April and October. The negative bias in the NH will be partly responsible for the relatively low background concentrations in the tropics, due to transport effects. The positive bias over South America could be explained from uncertainties related to emissions and chemistry of isoprene (see also next section). The largest $\mathrm{CO}$ concentrations at $\sim 500 \mathrm{hPa}$ are found over Southeast Asia and Indonesia, where strong biomass burning events took place in this year. The model shows negative biases of the order of $\sim 40 \mathrm{ppbv}$ over southern Africa and Indonesia in October. The global spatial correlation coefficient between TM5 and MOPITT at $500 \mathrm{hPa}$ is 0.91 in April and 0.79 in October.
Figure 5 shows the tropical and extra-tropical $\mathrm{NH}$ and $\mathrm{SH}$ monthly mean, mass weighted $\mathrm{CO}$ at $500 \mathrm{hPa}$ from MOPITT and the corresponding TM5 concentrations. In the NH TM5 underestimates CO at $500 \mathrm{hPa}$ by $\sim 20$ ppbv during winter-spring and $\sim 10$ ppbv during summer-autumn, consistent with analyses presented by Shindell et al. (2006). However, NH concentrations for MOPITT V4 are $\sim 5-15$ ppbv larger than those in MOPITT V3, as presented in Shindell et al. (2006). At the same time, TM5 NH CO has also increased because of larger $\mathrm{CO}$ emissions in Asia in the current inventory. The negative bias in the model can possibly be explained by missing $\mathrm{CO}$ emissions and/or missing emissions and chemistry from other NMVOC. For instance, preliminary tests where additional biogenic precursors such 
as methanol $\left(\mathrm{CH}_{3} \mathrm{OH}\right)$ are included into the chemical mechanism have been conducted using the emission database of Lathière et al. (2006). These tests indicate that the differences in the monthly mean distribution of $\mathrm{CO}$, especially during boreal summer, results in local increases in modeled $\mathrm{CO}$ of $\sim 10 \mathrm{ppbv}$. The bias in winter could further be explained by uncertainties in the seasonal cycle of anthropogenic emissions, as suggested by an inverse study of CO by Kopacz et al. (2010). Nevertheless, the phase of the seasonal cycles in TM5 and MOPITT appears to be in better agreement with the current model and data versions than in the comparison presented in Shindell et al. (2006).

Within the tropics, TM5 reproduces the observed seasonal cycle rather well, despite the presence of some spatial differences. This indicates that the previously observed positive and negative biases cancel out.

For the $\mathrm{SH}$, modeled and observed $\mathrm{CO}$ concentrations agree favorably during local summer, but the model underestimates $\mathrm{CO}$ during local spring by $\sim 10 \mathrm{ppbv}$. The increase in $\mathrm{CO}$ during local winter and spring is related to the long-range transport of CO from southern South America and southern Africa (e.g. de Gloudemans et al., 2006). Nevertheless, the results in Shindell et al. (2006) for the Southern Hemisphere show a larger inter-model variability than the bias found here, and the phase of the seasonal cycle in model and observations now agree very well.

For the evaluation of $\mathrm{CO}$ in the upper troposphere/lower stratosphere (UTLS) in-situ measurement data are used from flights between Frankfurt, Germany and Windhoek, Namibia, as part of the MOZAIC program (Measurement of Ozone and Water Vapour by Airbus In-Service Aircraft; e.g. Marenco et al., 1998; Thouret et al., 1998). An evaluation at pressure levels $<300 \mathrm{hPa}$ indicates a negative bias of the model in April of the order of $\sim 20$ ppbv, but somewhat smaller for latitudes above $40^{\circ} \mathrm{N}$ (cf. Fig. 6, left panel). Moreover, the variability of $\mathrm{CO}$ in the model is not as large as in the MOZAIC observations. The negative model bias in the UTLS in the tropics, combined with the (small) positive bias with respect to MOPITT could point at too weak convective uplift in tropical Africa in April. Such a mechanism could possibly also explain the positive bias compared to MOPITT over southern Asia in October, when the summer monsoon is active in this area.

The MOZAIC data shows a shift in $\mathrm{CO}$ from biomass burning from the $\mathrm{NH}$ during April to the SH during October. The negative bias against MOPITT over southern Africa suggests that the biomass burning emissions in this region are underestimated by the GFEDv2 dataset (Williams et al., 2010). This is supported by the relatively large negative bias of TM5 compared to MOZAIC observations ( $\sim 40 \mathrm{ppbv}$ in October between $5-17^{\circ} \mathrm{S}$ ).

\subsection{Formaldehyde $\left(\mathrm{CH}_{2} \mathrm{O}\right)$}

Formaldehyde $\left(\mathrm{CH}_{2} \mathrm{O}\right)$ is an abundant intermediate trace gas with a lifetime of typically a few hours. The highest concentrations are present in the tropics around regions exhibiting high methane and isoprene emissions. A budget analysis shows that the total $\mathrm{CH}_{2} \mathrm{O}$ chemical production in the current scheme is $1377 \mathrm{Tg} \mathrm{yr}^{-1}$, as shown in Table 10. Of this, $\sim 823 \mathrm{Tg} \mathrm{yr}^{-1}$ can be attributed to the oxidation of $\mathrm{CH}_{4}$, $157 \mathrm{Tg} \mathrm{yr}^{-1}$ to isoprene oxidation, and $397 \mathrm{Tg} \mathrm{yr}^{-1}$ to the oxidation of the other NMVOC. Moreover, the photolysis and oxidation of $\mathrm{CH}_{2} \mathrm{O}\left(1190 \mathrm{Tg} \mathrm{yr}^{-1}\right)$ is responsible for $\sim 95 \%$ of the total tropospheric chemical production of $\mathrm{CO}$.

Figure 7 shows the monthly mean SCIAMACHY total columns from the BIRA/KNMI retrieval (De Smedt et al., 2008) averaged onto the TM5 global resolution of $3^{\circ} \times 2^{\circ}$, compared to corresponding TM5 true monthly average (i.e. not sampled/no averaging kernel) tropospheric columns at 10:30 LT. The errors in the SCIAMACHY $\mathrm{CH}_{2} \mathrm{O}$ monthly mean data are estimated to range between 20-40\% (De Smedt et al., 2008). TM5 captures the different regions with high $\mathrm{CH}_{2} \mathrm{O}$ columns, e.g. over Southeast Asia in March and Central Africa in August. The spatial correlation coefficient between TM5 and SCIAMACHY in the tropical region $\left(20^{\circ} \mathrm{S}-20^{\circ} \mathrm{N}\right)$ ranges between 0.67 in June and 0.83 in September. Over the oceans the observations show generally higher columns than found in the model, but here the uncertainty in the retrievals is larger than over land (De Smedt et al., 2008).

The corresponding seasonal cycle of $\mathrm{CH}_{2} \mathrm{O}$ over a number of regions of interest is depicted in Fig. 8, along with the corresponding isoprene emissions. Over the eastern United States and eastern China the model shows an annual cycle with highest columns during JJA. Over eastern China the modeled concentrations match remarkably well with the observations, whereas over the eastern United States the model tends to overestimate $\mathrm{CH}_{2} \mathrm{O}$ during JJA. It should be noted that over eastern China the mean isoprene flux is lower than in the other regions, which suggests that the observed $\mathrm{CH}_{2} \mathrm{O}$ is dominated by oxidation of other hydrocarbons of anthropogenic origin, while both over eastern China and the eastern US the model is chemically more active due to high $\mathrm{NO}_{\mathrm{x}}$ concentrations.

Over Central Africa the average tropospheric columns from TM5 agree well with SCIAMACHY columns, but the small amplitude of the seasonal cycle is out of phase. Over South America (the Amazon region) TM5 overestimates $\mathrm{CH}_{2} \mathrm{O}$ concentrations systematically by $\sim 50 \%$. Here the isoprene emission flux is much larger than in other regions, e.g. the eastern United States. This high bias could be caused by uncertainties in isoprene chemistry (Houweling et al., 1998) and emissions (Stavrakou et al., 2009), which may also be related to the positive bias in $\mathrm{CO}$ over this region. Also uncertainty in $\mathrm{CH}_{2} \mathrm{O}$ from biomass burning contributes 

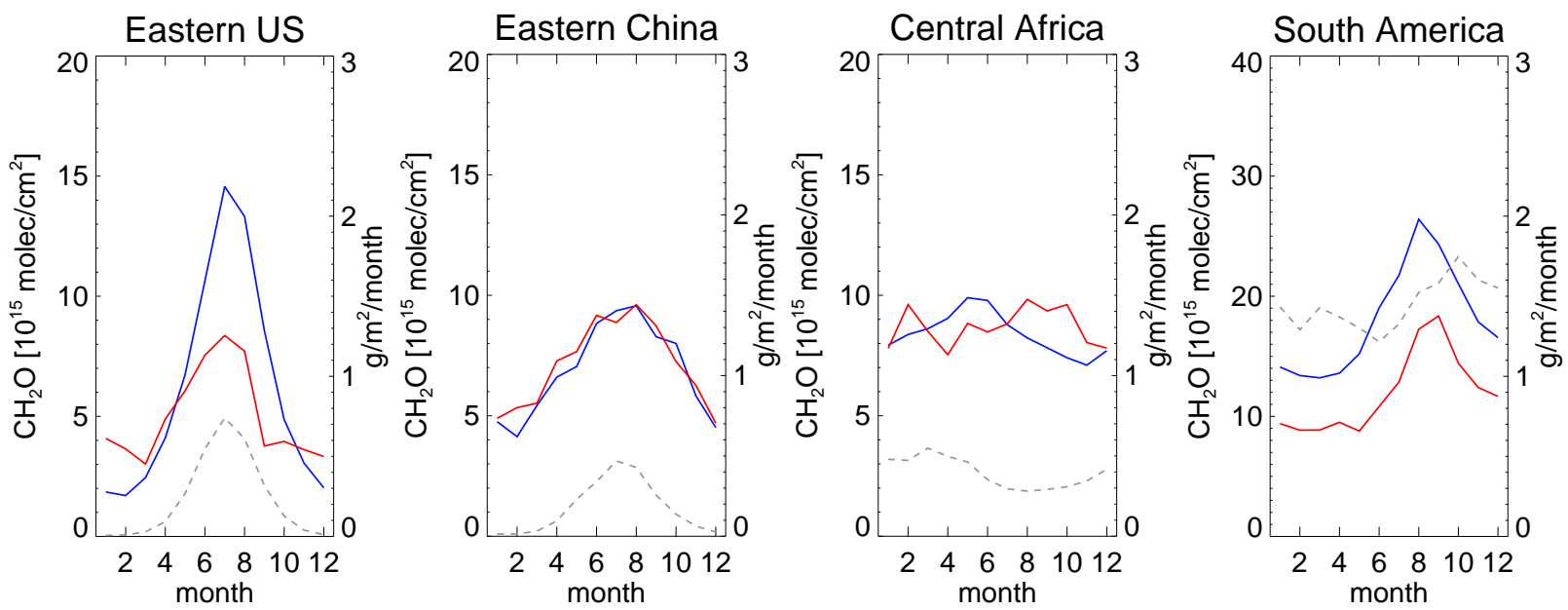

Fig. 8. The annual cycle in the observed (SCIAMACHY, red) and modeled (blue) $\mathrm{CH}_{2} \mathrm{O}$ tropospheric columns at 10:30 h LT over four selected regions. Dashed lines in grey indicate the isoprene emission flux in $\mathrm{g} / \mathrm{m}^{2} / \mathrm{month}$. Note the different scale for the columns over South America.

Table 10. Tropospheric $\mathrm{CH}_{2} \mathrm{O}$ budget in $\mathrm{Tg} \mathrm{CH}_{2} \mathrm{O} \mathrm{yr}-1$, as Table 9. Deposition contains both dry and wet contributions.

\begin{tabular}{llll}
\hline Emissions & $27(0.5 / 18 / 8)$ & Deposition & $214(13 / 167 / 34)$ \\
Trop. chem. production & $1377(90 / 1080 / 207)$ & Trop. chem. loss & $1190(78 / 931 / 181)$ \\
Total gain & $1404(91 / 1098 / 215)$ & Total loss & $1404(91 / 1098 / 215)$ \\
\hline
\end{tabular}

to the discrepancy between modeled and observed columns in August over the Amazon region (Barkley et al., 2008).

\subsection{Nitrogen dioxide $\left(\mathrm{NO}_{2}\right)$}

Tropospheric $\mathrm{NO}_{2}$ in TM5 is compared to OMI observations from the DOMINO product (version 1.0.2, Boersma et al., 2007, 2009). TM5 concentrations at the local overpass time of $13: 30 \mathrm{~h}$ are interpolated to satellite pixels and the averaging kernels are applied as described in Huijnen et al. (2010). Figure 9 shows that in general the model captures the large-scale spatial distribution of $\mathrm{NO}_{2}$ around the globe. The global spatial correlation coefficient of the annual mean tropospheric $\mathrm{NO}_{2}$ column density calculated for the global $3^{\circ} \times 2^{\circ}$ model grid is 0.89 . This is similar to that reported for the correlation between TM5 and GOME $\mathrm{NO}_{2}$ by Van Noije et al. (2006a). The model does not capture hotspots of $\mathrm{NO}_{2}$ over the Middle East and the Russian Republic, most probably due to uncertainties in the emission inventories for these regions. Also the small pixel size of OMI (approximately $0.2^{\circ} \times 0.2^{\circ}$ at nadir) allows for the detection of pollution hotspots that TM5 $\left(3^{\circ} \times 2^{\circ}\right)$ cannot capture.

In Fig. 10 the seasonal cycle over a selection of regions is presented. For almost all regions the modeled tropospheric columns are systematically lower compared to OMI, of the order of $0.5-1.0 \times 10^{15} \mathrm{molec} / \mathrm{cm}^{2}$, which is on the order of $25-40 \%$ of the magnitude of the observations. This discrep- ancy can partly be explained by a high bias of $0-30 \%$ in the OMI $\mathrm{NO}_{2}$ retrievals reported in earlier studies (Boersma et al., 2008; Huijnen et al., 2010; Zhou et al., 2009; Hains et al., 2010; Lamsal et al., 2010), but it is probable that uncertainties in the emission inventories also contribute to the bias between TM5 and OMI $\mathrm{NO}_{2}$. The largest differences are found for eastern China, where in winter observations reach levels of $10 \times 10^{15} \mathrm{molec} / \mathrm{cm}^{2}$, whereas TM5 does not exceed on average $7 \times 10^{15} \mathrm{molec} / \mathrm{cm}^{2}$, suggesting an underestimation in the REAS emission inventory.

The phase in the seasonal cycles of the $\mathrm{NO}_{2}$ columns is captured remarkably well by TM5. The seasonal cycle in both observations and model over the eastern US and Europe is smaller than in the TM5 results presented in Van Noije et al. (2006a), whereas for other regions the performance is rather similar.

$\mathrm{NO}_{2}$ vertical profiles from TM5 have been compared against in situ aircraft observations from the INTEX-B campaign (Intercontinental Chemical Transport Experiment B, Singh et al., 2009). We use the data that is measured by laserinduced fluorescence from the DC8 aircraft during its ascents and descents (Thornton et al., 2000; Perring et al., 2010). Model profiles were produced by interpolating model output in space and time to individual data sampled from all respective flights. A selection of data samples which showed clear signs of strong local pollution events have been excluded 

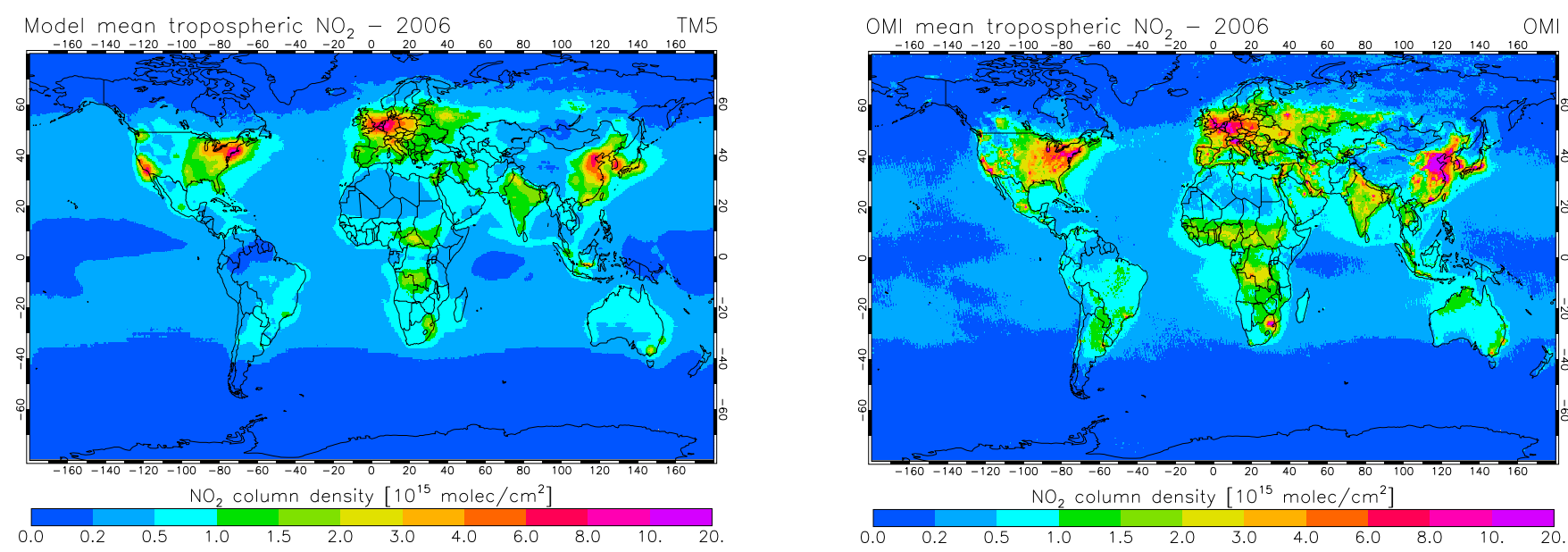

Fig. 9. TM5 annual mean tropospheric $\mathrm{NO}_{2}$ column density versus $\mathrm{OMI}$.
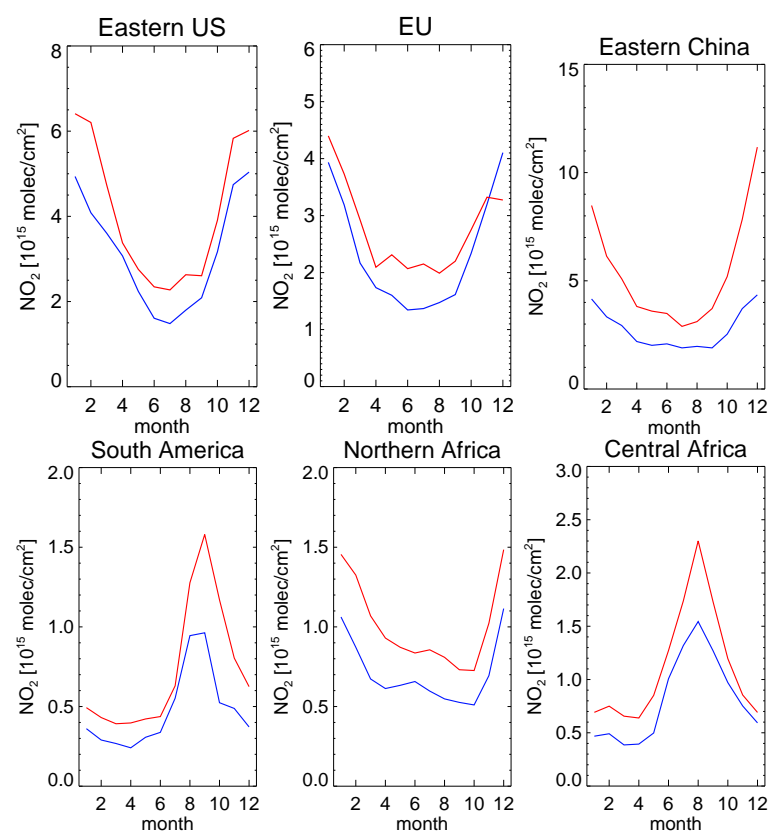

Fig. 10. Annual cycle of regionally and monthly averaged $\mathrm{NO}_{2}$ tropospheric columns from TM5 (blue) against OMI (red).

from this analysis. Figure 11 shows that TM5 captures the range of $\mathrm{NO}_{2}$ concentrations in the boundary layer and free troposphere within $0.1 \mathrm{ppbv}$, both in the morning and in the afternoon.

\subsection{Nitrogen deposition}

The annual average total deposition (dry and wet) for $\mathrm{NH}_{\mathrm{x}}$ $\left(=\mathrm{NH}_{3}+\mathrm{NH}_{4}^{+}\right)$and $\mathrm{NO}_{\mathrm{y}}$ are presented in Fig. 12. Over Europe, India, China and parts of Central Africa the $\mathrm{NH}_{\mathrm{x}}$ deposition exceeds values of $1000 \mathrm{mg} \mathrm{N} / \mathrm{m}^{2} /$ year. Except for Africa, where $\mathrm{NH}_{\mathrm{x}}$ deposition is relatively large, the model
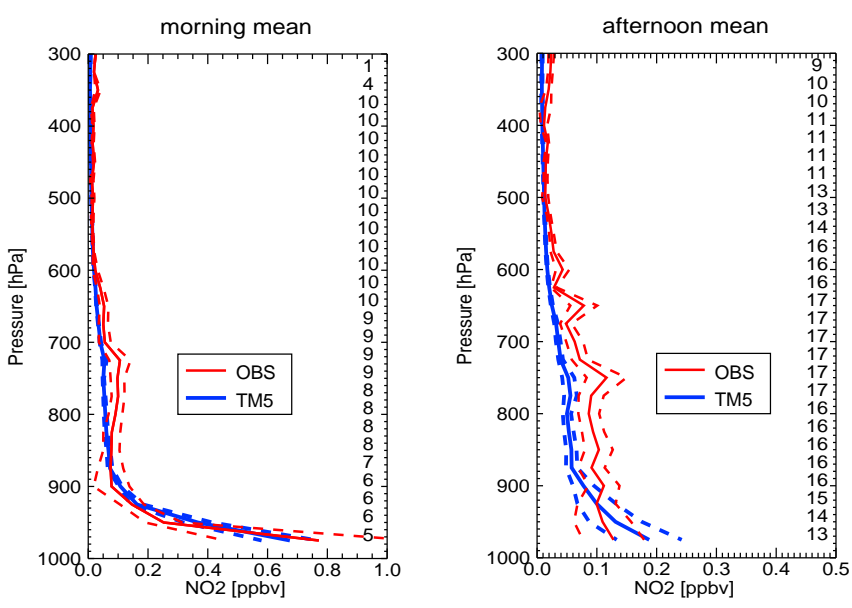

Fig. 11. Comparison of TM5 $\mathrm{NO}_{2}$ profiles to aircraft measurements from the INTEX-B campaign over Mexico and the Gulf of Mexico during March 2006. Data is split into local times between 08:0011:00 h (morning mean, left panel) and 11:00-16:00 h (afternoon mean, right panel). On the right side of the panels the number of available measurements in $25-\mathrm{hPa}$ pressure bins is given. Dashed lines indicate the standard deviation of all individual observations and model results with respect to their means.

results are generally in line with the multi-model mean presented in the study by Dentener et al. (2006c), based on an ensemble of 23 models. For $\mathrm{NO}_{\mathrm{y}}$ deposition TM5 is somewhat larger over India and Central Africa than the ensemble mean. $\mathrm{HNO}_{3}$ wet deposition is further compared against deposition measurements from the National Atmospheric Deposition Program (NADP) network in North America, the European Monitoring and Evaluation Programme (EMEP) network, and data from IDAF (IGAC DEBITS Africa), all for the year 2000 (see Fig. 13). The current TM5 model somewhat underestimates the $\mathrm{HNO}_{3}$ wet deposition in the given regions, but still $74 \%-80 \%$ of the model data falls within the 

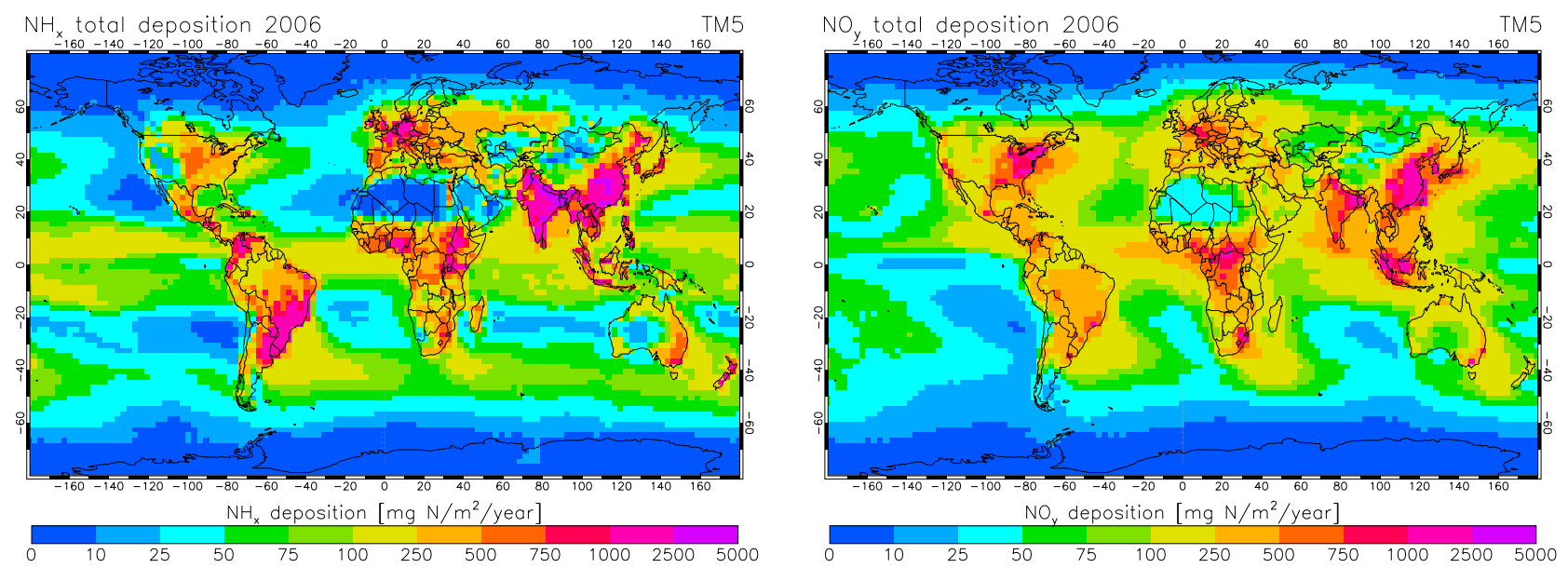

Fig. 12. Annual $\mathrm{NH}_{\mathrm{x}}$ and $\mathrm{NO}_{\mathrm{y}}$ dry and wet deposition in $\mathrm{TM} 5$ for 2006.
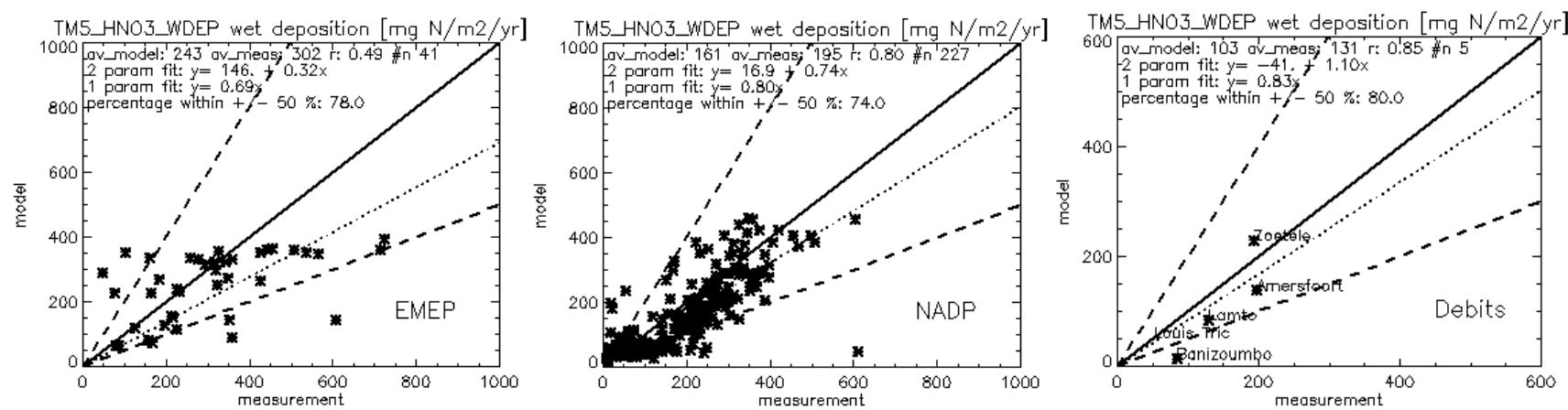

Fig. 13. Scatter plots of the simulated $\mathrm{HNO}_{3}$ wet deposition versus measurements for three networks in Europe (left panel), North America (middle panel), and Africa (right panel). Dashed lines have slopes equal to 2 resp. 0.5. The dotted line is the result of linear regression fitting through the origin.

range of $\pm 50 \%$ of the measurements. This is well in line with the performance of the ensemble mean and also similar to the TM5 evaluation presented in Dentener et al. (2006c). The total (dry and wet) deposition of $\mathrm{NO}_{\mathrm{y}}$ is equal to the total $\mathrm{NO}$ emissions, while the wet deposition adds up to $58 \%$ of the total deposition. This is in the middle of the range from the multi-model ensemble (40\%-70\%). For $\mathrm{NH}_{x}$ the wet deposition contributes $45 \%$ to the total deposition, which is a relatively low fraction compared to the range (40\%-80\%) from the 5 models that analyzed this contribution in Dentener et al. (2006c). This reflects large uncertainties and differences in assumptions regarding $\mathrm{NH}_{4}^{+}$deposition across models.

\subsection{Ozone $\left(\mathrm{O}_{3}\right)$}

In this section we evaluate tropospheric $\mathrm{O}_{3}$ and provide details regarding the ozone budget (see Table 11). Compared to the TM5 model version included in the study of Stevenson et al. (2006), the stratosphere-troposphere exchange of $\mathrm{O}_{3}$ has decreased significantly (by $\sim 52 \%$ ), mainly because in the extra-tropics the level above which stratospheric ozone is re- laxed has been brought down (Van Noije et al., 2004). The newly calculated net flux of $421 \mathrm{Tg} / \mathrm{yr}$, with an uncertainty of $\sim 20 \mathrm{Tg} / \mathrm{yr}$ due to variations in the definition of the troposphere (here taken as $\left[\mathrm{O}_{3}\right]<150 \mathrm{ppbv}$ similar to Stevenson et al., 2006), is within one standard deviation of the multimodel mean. The chemical production and loss terms in the troposphere are also decreased (by $\sim 6.4 \%$ and $\sim 16 \%$, respectively). This is due to a larger fraction of the $\mathrm{NO}_{\mathrm{x}}$ being held in the form of ORGNTR as a result of the updates to the chemical reaction data (Williams and Van Noije, 2008), but other factors such as changes in the assumed amount and distribution of emissions of $\mathrm{NO}_{\mathrm{x}}$ and other $\mathrm{O}_{3}$ precursor gases also play a role. The combined effect of these changes is a reduction of the tropospheric $\mathrm{O}_{3}$ burden by $\sim 8 \%$ compared to the number reported by Stevenson et al. (2006). As mentioned in Sect. 5.1, the methane lifetime in the current scheme is $\sim 8.9 \mathrm{yr}$, compared to $\sim 7.9 \mathrm{yr}$ in the TM5 version presented in Stevenson et al. (2006). This is in line with the decrease in the tropospheric $\mathrm{O}_{3}$ burden and a decrease in $\mathrm{OH}$, also in relation to the recently changed $\mathrm{CO}+\mathrm{OH}$ reaction constant (Sect. 3.1). 

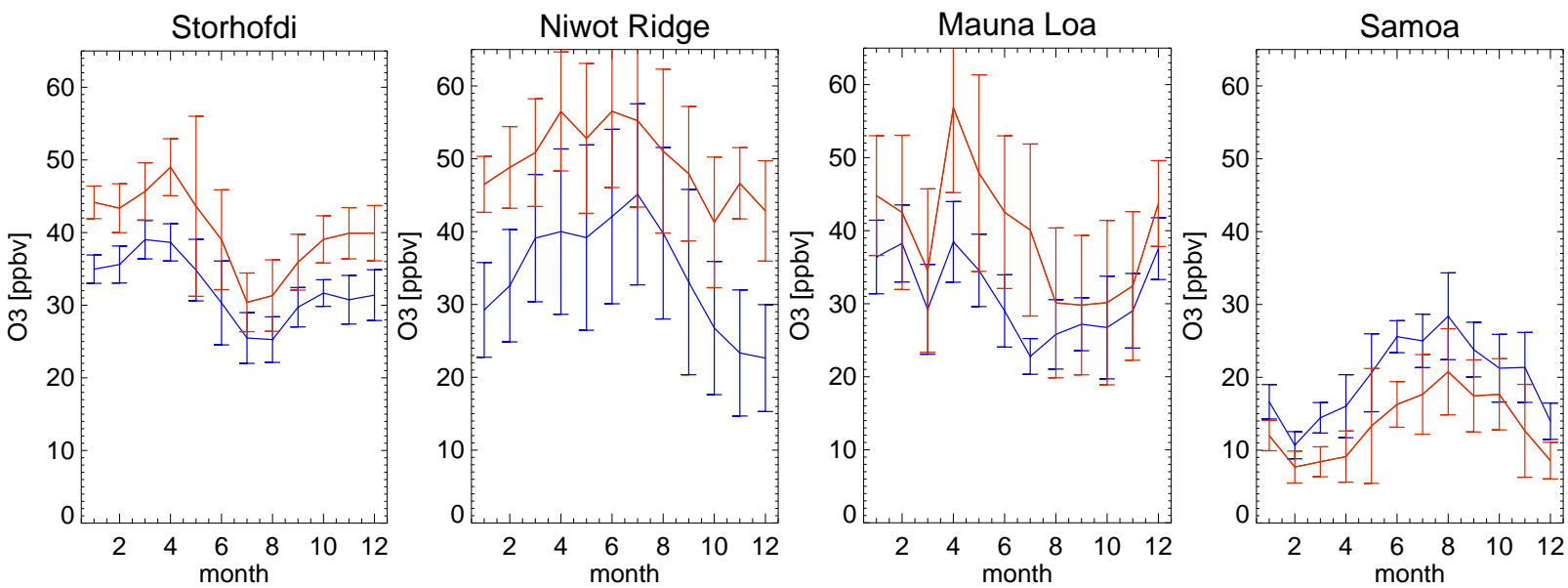

Fig. 14. The annual cycle in the simulated ozone concentrations (blue) compared to surface measurements from the GMD network (red) at the stations Storhofdi, Iceland $\left(63.3^{\circ} \mathrm{N}, 20.3^{\circ} \mathrm{W}\right)$, Niwot Ridge $\left(41.1^{\circ} \mathrm{N}, 124.2^{\circ} \mathrm{W}\right)$, Mauna Loa $\left(19.5^{\circ} \mathrm{N}, 155.6^{\circ} \mathrm{W}\right)$, and Samoa $\left(14^{\circ} \mathrm{S}\right.$, $\left.170.5^{\circ} \mathrm{W}\right)$. Model data has been sampled at the time of the observations. The error bars indicate the standard deviation in the monthly means.
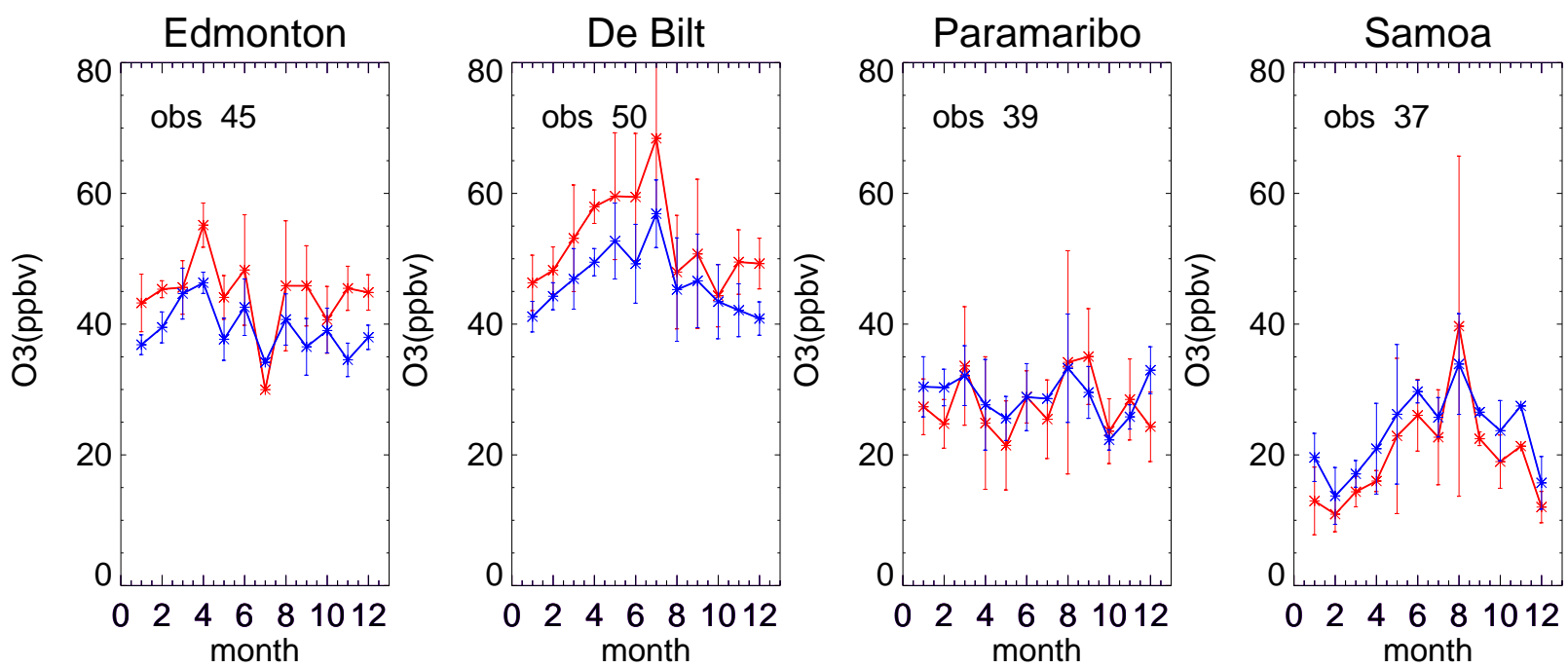

Fig. 15. The annual cycle in the simulated ozone concentrations (blue) in the layers between $800-700 \mathrm{hPa}$ compared to WOUDC sonde observations (red) at the stations Edmonton $\left(53.5^{\circ} \mathrm{N}, 114^{\circ} \mathrm{W}\right)$, De Bilt $\left(52^{\circ} \mathrm{N}, 5.2^{\circ} \mathrm{E}\right)$, Paramaribo $\left(5.9^{\circ} \mathrm{N}, 55.2^{\circ} \mathrm{W}\right)$, and $\mathrm{Samoa}\left(14^{\circ} \mathrm{S}\right.$, $\left.170.5^{\circ} \mathrm{W}\right)$. Model data is sampled at the time of the observations. The error bars indicate the standard deviation in the monthly means.

Figure 14 shows a comparison of simulated surface ozone concentrations against GMD surface observations at several sites. An extended evaluation against other GMD stations is given in the supplementary material. The phase and amplitude is generally well captured, but the model shows a negative offset of $\sim 5-15 \mathrm{ppbv}$ over the NH and tropical stations, and a small positive bias at Samoa.

To assess the vertical distribution throughout the troposphere the model data is compared to ozone sonde measurements at various latitudes, as available from the World Ozone and Ultraviolet Radiation Data Centre (WOUDC). In Fig. 15 the simulated $\mathrm{O}_{3}$ mixing ratios averaged over an altitude range between $700-800 \mathrm{hPa}$ are compared to sonde obser- vations taken at northern midlatitudes (Edmonton, De Bilt) and in the tropics (Paramaribo, Samoa). Figure 16 shows corresponding comparisons of the vertical profiles for the selected stations. These figures show that there is a small negative bias of the order of 5-10 ppbv over the $\mathrm{NH}$, although the model captures the seasonal variation relatively well. An extended evaluation made against additional sonde stations for all seasons is provided in the supplementary material.

In the tropics the average concentrations over Paramaribo between $700-800 \mathrm{hPa}$ are well in line with observations, but the simulated profile has a too weak vertical gradient with too high concentrations near the surface and too low concentrations in the upper troposphere. The relatively low 

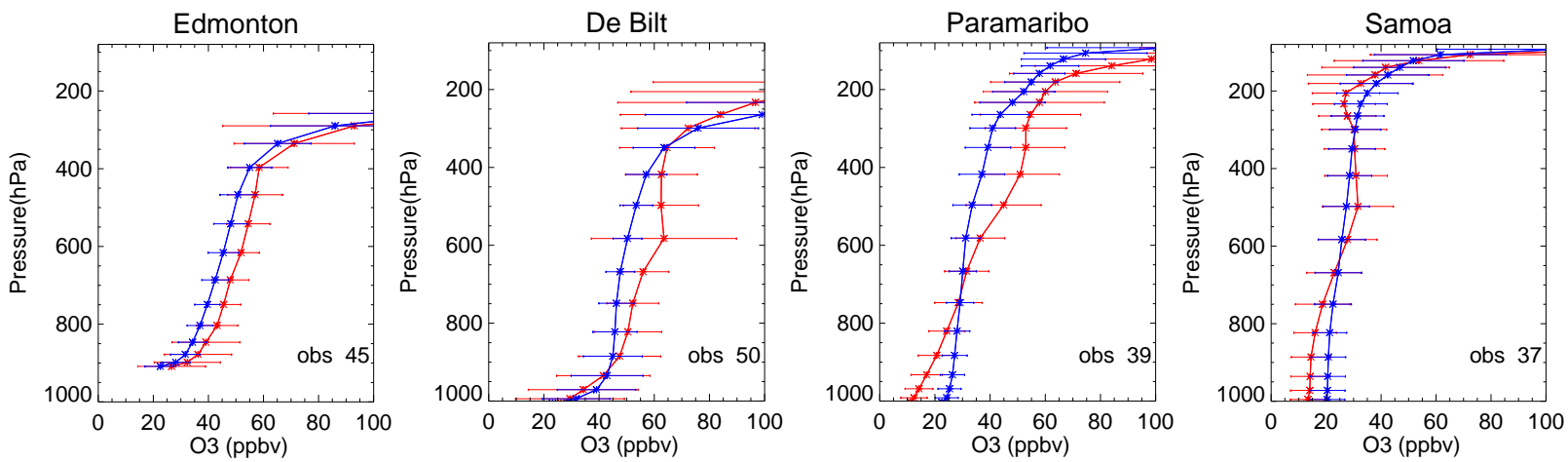

Fig. 16. The annual average modeled ozone profiles (blue) compared to WOUDC sonde observations (red) for the stations shown in Fig. 15.
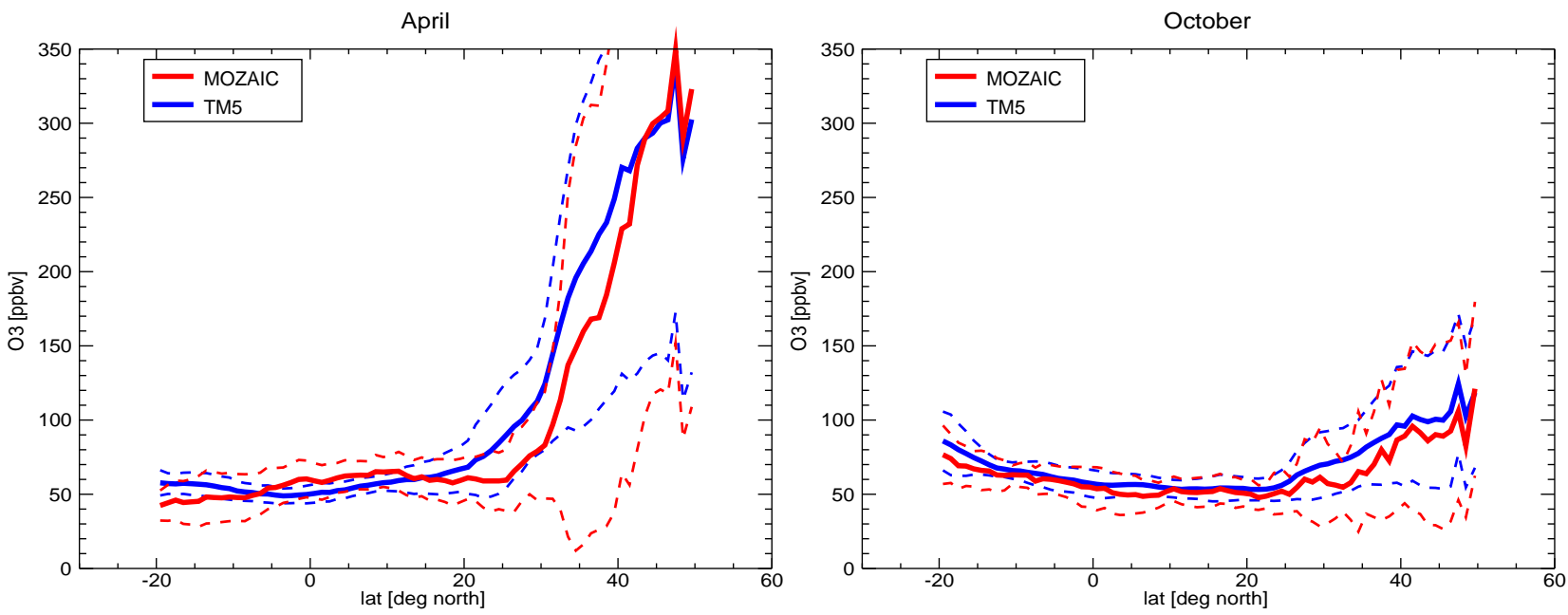

Fig. 17. Comparison of monthly average MOZAIC flight data for $\mathrm{O}_{3}$, as in Fig. 6 .

concentrations in the upper troposphere in the tropics are also found at several other sites, e.g. Natal $\left(5.8^{\circ} \mathrm{S}, 35.2^{\circ} \mathrm{W}\right)$, Cotonou $\left(6.2^{\circ} \mathrm{N}, 2.2^{\circ} \mathrm{E}\right)$, Nairobi $\left(1.3^{\circ} \mathrm{S}, 36.8^{\circ} \mathrm{E}\right)$ (see supplementary material) and require further investigation.

For the SH there is generally good agreement between modeled $\mathrm{O}_{3}$ concentrations and observations with respect to both the seasonal cycle and the yearly averaged vertical profile. Together with the evaluation of $\mathrm{CO}$ this suggests that the chemical scheme is able to model the chemical composition of the atmosphere at remote locations away from direct emission sources.

Figure 17 shows a comparison of $\mathrm{O}_{3}$ mixing ratios in the UTLS (pressure levels $<300 \mathrm{hPa}$ ) between those simulated in TM5 and the MOZAIC data record as a function of latitude. Generally there is good agreement for both the mean and the spread in the observed values. The variability is somewhat larger in the observations than in TM5. This could be caused by the applied relaxation of the zonal mean stratospheric ozone fields combined with the limited vertical resolution in the UTLS region in this model version.
Surface $\mathrm{O}_{3}$ concentrations can be sensitive to the spatial resolution in the model due to local chemical composition and deposition velocities, especially close to emission regions. An evaluation of modeled $\mathrm{O}_{3}$ concentrations against observations from the EMEP network presented in Appendix B shows generally good consistency of the model with varying resolutions. Only at grid boxes that overlap land-sea boundaries $\mathrm{O}_{3}$ concentrations may vary significantly with changing horizontal resolution, probably due to the spatial partitioning of $\mathrm{NO}_{\mathrm{x}}$ emissions over the different grid-boxes. The variability of ozone concentrations at the surface can potentially be enhanced by improving the spatiotemporal distribution of the ozone precursor emissions.

\section{Summary}

A comprehensive description has been given of the tropospheric chemistry version of the global chemistry and transport model TM5. The large-scale variability in space and time of modeled tropospheric ozone and related tracers has been evaluated for the year 2006 and compared to surface, 
Table 11. The tropospheric chemical budget of $\mathrm{O}_{3}$ given in $\mathrm{Tg} \mathrm{O}_{3} \mathrm{yr}^{-1}$, similar to Table 9. The stratospheric inflow is calculated as the sum of the deposition and the tropospheric chemical loss minus production.

\begin{tabular}{llll}
\hline Stratospheric inflow & 421 & Deposition & $829(97 / 426 / 306)$ \\
Trop. chem. production & $4289(292 / 3108 / 889)$ & Trop. chem. loss & $3881(313 / 2950 / 618)$ \\
Trop. burden & $312(63 / 165 / 84)$ & Lifetime (days) & $24.2(56.1 / 17.8 / 33.2)$ \\
\hline
\end{tabular}

airborne and satellite observations, as well as earlier TM5 model versions documented in literature.

The evaluation of $\mathrm{OH}$ against methyl chloroform (MCF) observations shows a good correspondence with a MCF lifetime of $\sim 5.86 \mathrm{yr}$, which is very similar to the $5.76 \mathrm{yr}$ found using an optimized climatological $\mathrm{OH}$ field. The methane lifetime in the model is $\sim 8.9 \mathrm{yr}$, which is slightly longer than the range $8.45 \pm 0.38$ yr estimated by Stevenson et al. (2006). These results indicate that the oxidizing capacity is well represented at a global scale.

The phase and amplitude of the seasonal cycles of $\mathrm{CO}$ at $500 \mathrm{hPa}$ in TM5 and MOPITT are very similar. However, the model underestimates $\mathrm{CO}$ in the Northern Hemisphere by $\sim 20$ ppbv during winter-spring and $\sim 10 \mathrm{ppbv}$ during summer-autumn. This is most likely related to missing emissions and underestimated chemistry from other NMVOC, such as methanol oxidation, and uncertainties in the seasonal cycle of anthropogenic emissions. In the tropics local positive biases cancel out a negative bias from the background $\mathrm{CO}$ concentrations. Uncertainties relate to, e.g., the representation of biomass burning $\mathrm{CO}$ emissions, their injection heights and their convective redistribution.

The model captures the spatial and seasonal variation in formaldehyde tropospheric columns as observed from SCIAMACHY. Positive model biases over the Amazon region and the eastern US indicate uncertainties in the emissions and chemical breakdown of isoprene.

The comparison with observed tropospheric $\mathrm{NO}_{2}$ columns from OMI shows that TM5 reproduces the seasonality as well as the spatial variability (correlation coefficient of 0.89 ), but systematically underestimates the observations by $25-40 \%$. Earlier studies indicated that $\mathrm{OMI} \mathrm{NO}_{2}$ is likely biased high by $0-30 \%$, but errors in the emission inventories are likely to contribute to the discrepancy as well. An evaluation of $\mathrm{NO}_{2}$ profiles over (the Gulf of) Mexico against aircraft measurements from the INTEX-B campaign shows that TM5 captures the $\mathrm{NO}_{2}$ concentrations in the troposphere on average within $0.1 \mathrm{ppbv}$ and simulates the observed increase of the boundary layer height during daytime well.

$74 \%-80 \%$ of model data for $\mathrm{HNO}_{3}$ wet deposition falls within the range of $\pm 50 \%$ of measurements in Europe, North America and Africa, which is well in line with the performance of the ensemble mean presented in Dentener et al. (2006c).
The ozone budget is within one standard-deviation of the multi-model ensemble presented in Stevenson et al. (2006). The model captures the spatial and seasonal variation in observed background surface $\mathrm{O}_{3}$ concentrations and tropospheric $\mathrm{O}_{3}$ profiles generally within 10 ppbv. We find a small negative bias of 5-10 ppbv at an altitude range between 700 $800 \mathrm{hPa}$ over sonde stations in the $\mathrm{NH}$, while a good agreement is found in the SH. Also ozone in the UTLS matches on average within $10 \mathrm{ppbv}$ with MOZAIC data, although the model is not able to capture all of the observed variability. This could be caused by the constraints of the zonal mean stratospheric ozone fields and the limited vertical resolution in the UTLS region in this model version. In the tropics the model tends to underestimate $\mathrm{O}_{3}$ in the free troposphere.

The presented model results benchmark the TM5 tropospheric chemistry version, which is currently in use in several international cooperation activities, and upon which new model improvements will take place.

\section{Appendix A}

\section{Evaluation of methyl chloroform}

To validate the $\mathrm{OH}$ field from the TM5 tropospheric chemistry model, the monthly mean $\mathrm{OH}$ fields from this study for the year 2006 were applied in a coarse-grid $\left(6^{\circ} \times 4^{\circ}, 25\right.$ vertical layers) TM5 simulation of methyl chloroform (MCF) over the years 1989-2006, using ECMWF ERA-Interim meteorology, where the oxidation of $\mathrm{MCF}$ by $\mathrm{OH}$ is the predominant loss term in the troposphere. Small sink terms for oceanic loss and stratospheric photolysis are included according to Krol and Lelieveld (2003). For 1989-1999 the MCF emissions used in the simulation are similar to those used by Prinn et al. (2005). For the later years we used slightly higher emissions compared to Prinn et al. (2005), which amount to $26.0,17.8,16.1,13.1,10.8,8.8$, and $7.2 \mathrm{Gg} \mathrm{yr}^{-1}$ for 2000-2006. The results for these more recent years do not critically depend on the applied emissions, since the atmospheric MCF concentration in this period is primarily determined by the atmospheric reservoir built up in the 1980s and 1990s. We also performed simulations using the monthly $\mathrm{OH}$ fields constructed by Spivakovsky et al. (2000), which we multiplied by a factor 0.92 to obtain a good correspondence with the observed methyl chloroform decay rate in the atmosphere since 2000. In these simulations 

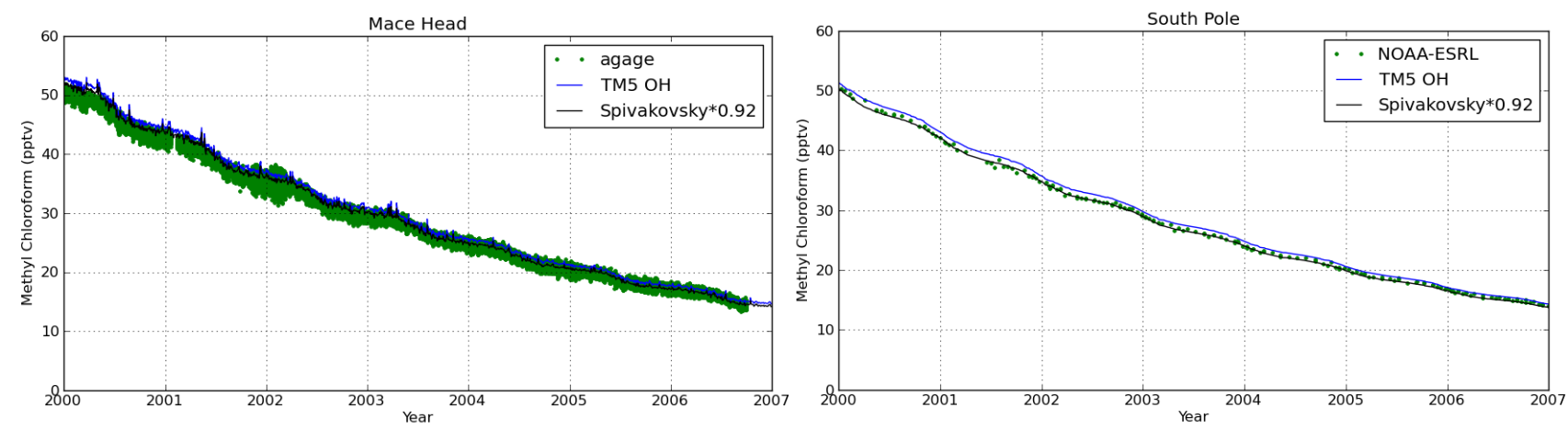

Fig. A1. Simulated methyl chloroform mixing ratios compared to observations using monthly mean OH fields from the 2006 tropospheric chemistry simulation (blue line) and from Spivakovsky et al. (2000), multiplied by 0.92 (black line). Upper panel: NOAA-ESRL station South Pole. Lower panel: AGAGE station Mace Head (Ireland).
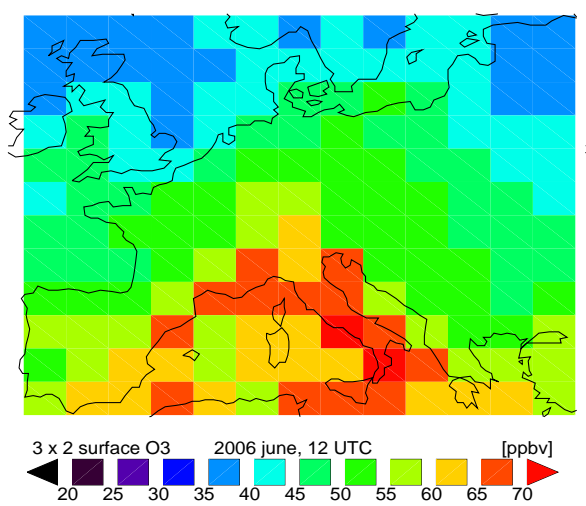
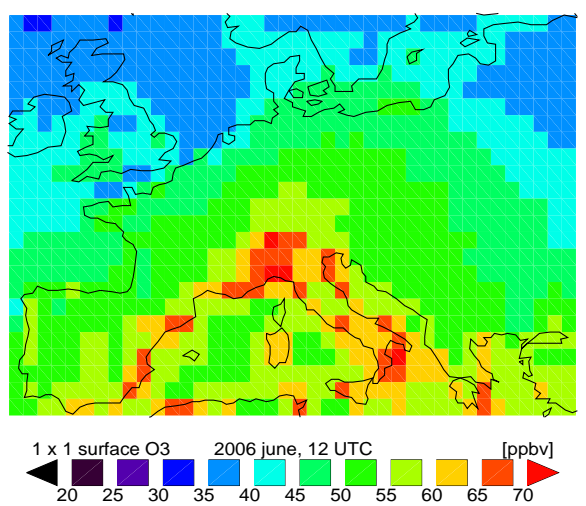
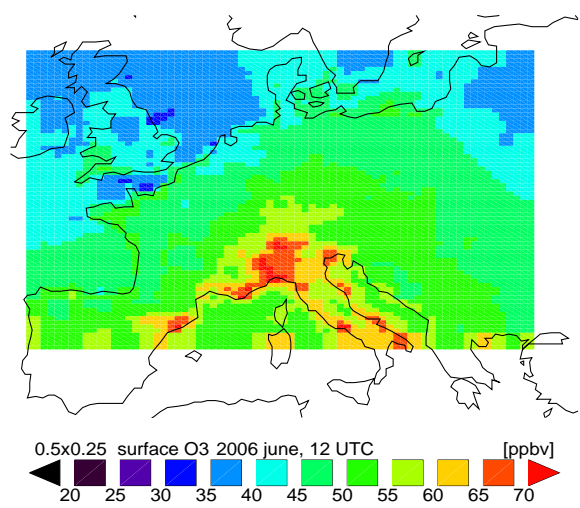

Fig. B1. Monthly mean surface ozone fields over Europe for June 2006 at 12:00 UTC, as simulated with increasing levels of zoom.

$\mathrm{OH}$ in the stratosphere was obtained from a 2-D stratospheric model simulation (C. Brühl, personal communication) and was merged with the Spivakovsky tropospheric $\mathrm{OH}$ field.

In Fig. A1 we compare the simulated MCF decay in the 2000-2006 period to NOAA observations downloaded from the World Data Centre for Greenhouse Gases (WDCGG). From the figure it is clear that the MCF decay since 2000 is very well modeled by TM5 with either the $\mathrm{OH}$ fields simulated with the tropospheric chemistry version of TM5 or the down-scaled Spivakovsky fields. The simulated $\mathrm{OH}$ results in somewhat higher MCF mixing ratios, which indicates that the TM5 OH fields may be slightly too low. Given the uncertainties in MCF emissions and the other MCF sinks, the results are considered very good, however. Note also that especially before 2002 the calibration of the NOAA-ESRL and AGAGE network show some systematic differences, with AGAGE mixing ratios being slightly lower at common measurement locations (S. Montzka, personal communication; http://gaw.kishou.go.jp/wdcgg/).

\section{Appendix B}

\section{Resolution dependence of surface ozone}

In regions with large gradients in $\mathrm{NO}_{\mathrm{x}}$ emissions in space and time, the observed ozone concentrations can show significant variation (Wild et al., 2006). This can only be captured in a model with sufficient spatial and temporal resolution. TM5 has the option to zoom in over such emission regions. Here we evaluate the resolution dependence in surface $\mathrm{O}_{3}$ at background stations from the EMEP European air quality network.

Two sensitivity runs have been performed for a one-month time period (June 2006), one with a single zoom region of $1^{\circ} \times 1^{\circ}$ over Europe ranging from $\left[21^{\circ} \mathrm{W}-39^{\circ} \mathrm{E} \times 12^{\circ} \mathrm{N}-\right.$ $\left.66^{\circ} \mathrm{N}\right]$, and a second region with two levels of zoom, with its highest resolution at $0.5^{\circ} \times 0.25^{\circ}\left[9^{\circ} \mathrm{W}-27^{\circ} \mathrm{E} \times 40^{\circ} \mathrm{N}-\right.$ $60^{\circ} \mathrm{N}$ ] nested inside the $1^{\circ} \times 1^{\circ}$ region.

Figure $\mathrm{B} 1$ indicates a clear increase of the spatial details in the average $\mathrm{O}_{3}$ fields with an increase in grid resolution This mostly affects the coastal regions. The region around the 
Table B1. Average temporal correlation coefficient and RMSE (ppbv) for June 2006 compared to EMEP data at the station locations shown in Fig. B2 as a function of horizontal resolution, taking data for the whole day or sampled only at 15:00 or 03:00 UTC.

\begin{tabular}{ccccccc}
\hline & \multicolumn{3}{c}{ Correlation coefficient } & \multicolumn{3}{c}{ RMSE } \\
& full day & $15: 00$ & $03: 00$ & full day & $15: 00$ & $03: 00$ \\
\hline $3^{\circ} \times 2^{\circ}$ & 0.58 & 0.55 & 0.44 & 13.8 & 12.8 & 14.5 \\
$1^{\circ} \times 1^{\circ}$ & 0.59 & 0.55 & 0.48 & 13.4 & 12.6 & 14.1 \\
$0.5^{\circ} \times 0.25^{\circ}$ & 0.59 & 0.56 & 0.48 & 13.3 & 12.3 & 14.0 \\
\hline
\end{tabular}

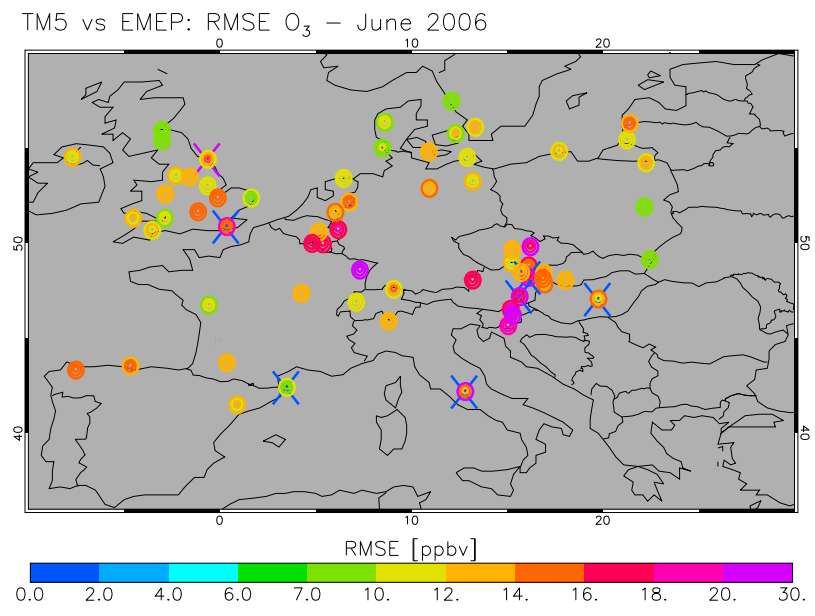

Fig. B2. Root mean square error (RMSE) of modeled surface ozone against hourly EMEP station data at stations below $800 \mathrm{~m}$ altitude. Outer circles: $3^{\circ} \times 2^{\circ}$ run, middle circles: $1^{\circ} \times 1^{\circ}$, inner circles: $0.5^{\circ} \times 0.25^{\circ}$. Blue crosses denote locations where an increase in resolution leads to a consistent reduction in RMSE with more than 2 ppbv for both zoom runs, compared to the $3^{\circ} \times 2^{\circ}$ run. Purple crosses denote a similar consistent increase in RMSE.

Mediterranean shows an average decrease in ozone concentrations. This can be explained by the fact that NO emissions remain more confined with increasing resolution, affecting the photochemical equilibrium over the cleaner Mediterranean Sea (ozone titration by high local NO emissions). In coarser model resolutions the NO emissions are spread out over larger boxes, which leads to $\mathrm{NO}_{\mathrm{x}}$ concentrations that are more favorable for photochemical ozone production.

In Fig. B2 an evaluation of the root mean square error (RMSE) compared to EMEP station measurements is presented. The figure indicates that for most stations the RMSE value remains constant, indicating a good consistency between runs with increasing resolution. For a small number of stations (two located in the Mediterranean region, one at the South coast of England, two in Austria, and one in Hungary) we observe a significant improvement with increasing resolution. Only one station shows a significant decrease in the RMSE. The average correlation coefficient and RMSE values for all stations are given in Table B1. It shows a small, but consistent improvement of the scores with increasing resolution.
The lack of significant improvement for the majority of stations can be caused by the fact that the current model version has not been optimized for air quality applications. For instance, a high-resolution emission inventory developed for use in air quality modeling would show larger spatial variation than the current $0.5^{\circ} \times 0.5^{\circ}$ RETRO inventory (Huijnen et al., 2010). Also a diurnal cycle in $\mathrm{NO}_{\mathrm{x}}$ emissions can significantly affect the $\mathrm{NO}_{\mathrm{x}}$ concentrations (de Meij et al., 2006), and hence the ozone budget. Without a diurnal cycle too much NO is introduced in the model during nighttime, leading to an overestimation of the ozone titration. A weekly emission cycle would also lead to a higher temporal variability. The ozone removal is strongly dependent on assumptions about surface properties, boundary layer turbulence and surface layer thickness (Ganzeveld and Lelieveld, 1995). Currently in all simulations the deposition velocity was evaluated at a common resolution of $1^{\circ} \times 1^{\circ}$, which suppresses the resolution dependence.

\section{Supplementary material related to this article is available online at: http://www.geosci-model-dev.net/3/445/2010/ gmd-3-445-2010-supplement.pdf.}

Acknowledgements. The MOPITT team is acknowledged for making their observations publicly available via the NASA Langley Atmospheric Science Data Center. SCIAMACHY is a joint project of the German Space Agency DLR and the Dutch Space Agency NIVR with contribution from the Belgian Space Agency. The OMI project is managed by NIVR and KNMI in The Netherlands. We acknowledge the free use of tropospheric $\mathrm{NO}_{2}$ column data from OMI from www.temis.nl. The NOAA-ESRL GMD is acknowledged for providing $\mathrm{CO}$ and $\mathrm{O}_{3}$ surface measurement data. We are grateful to the WOUDC community for making their ozone sonde data available. The authors acknowledge for the strong support of the European Commission, Airbus, and the Airlines (Lufthansa, Austrian, Air France) who carry free of charge the MOZAIC equipment and perform the maintenance since 1994. MOZAIC is presently funded by INSU- CNRS (France), Météo-France, and Forschungszentrum Jülich (Germany). The MOZAIC data based is supported by ETHER (CNES and INSU-CNRS). AGAGE and NOAA-ESRL teams are acknowledged for the methyl chloroform measurements.

Edited by: V. Grewe 


\section{References}

Aan de Brugh, J. M. J., Schaap, M., Vignati, E., Dentener, F., Kahnert, M., Sofiev, M., Huijnen, V., and Krol, M. C.: The European aerosol budget in 2006, Atmos. Chem. Phys. Discuss., 10, 21391-21437, doi:10.5194/acpd-10-21391-2010, 2010.

Anderson, G., Clough, S., Kneizys, F., Chetwynd, J., and Shettle, E.: AFGL atmospheric constituent profiles (0-120 km), AFGLTR-86-0110. Air Force Geophys. Lab., Hanscom Air Force Base, Bedford, Mass, 1986.

Atkinson, R., Baulch, D. L., Cox, R. A., Crowley, J. N., Hampson, R. F., Hynes, R. G., Jenkin, M. E., Rossi, M. J., and Troe, J.: Evaluated kinetic and photochemical data for atmospheric chemistry: Volume $\mathrm{I}$ - gas phase reactions of $\mathrm{O}_{\mathrm{x}}, \mathrm{HO}_{\mathrm{x}}, \mathrm{NO}_{\mathrm{x}}$ and $\mathrm{SO}_{\mathrm{x}}$ species, Atmos. Chem. Phys., 4, 1461-1738, doi:10.5194/acp-41461-2004, 2004.

Atkinson, R., Baulch, D. L., Cox, R. A., Crowley, J. N., Hampson, R. F., Hynes, R. G., Jenkin, M. E., Rossi, M. J., Troe, J., and IUPAC Subcommittee: Evaluated kinetic and photochemical data for atmospheric chemistry: Volume II - gas phase reactions of organic species, Atmos. Chem. Phys., 6, 3625-4055, doi:10.5194/acp-6-3625-2006, 2006.

Barkley, M. P., Palmer, P. I., Kuhn, U., Kesselmeier, J., Chance, K., Kurosu, T. P., Martin, R. V., Helmig, D., and Guenther, A.: Net ecosystem fluxes of isoprene over tropical South America inferred from Global Ozone Monitoring Experiment (GOME) observations of HCHO columns, J. Geophys. Res., 113, D20304, doi:10.1029/2008JD009863, 2008.

Bergamaschi, P., Frankenberg, C., Meirink, J. F., Krol, M. C., et al.: Inverse modeling of global and regional $\mathrm{CH} 4$ emissions using SCIAMACHY satellite retrievals, J. Geophys. Res., 114, D22301, doi:10.1029/2009JD012287, 2009.

Berkvens, P. J. F., Botchev, M. A., Lioen, W. M., and Verwer, J. G.: A zooming technique for wind transport of air pollution, Report MAS-R9921, Centrum Wiskunde \& Informatica (CWI), Amsterdam, The Netherlands, 1999.

Betterton, E. A. and Hoffmann, M. R.: Henry's law constants of some environmentally important aldehydes, Environ. Sci. Technol., 22, 1415-1418, 1988.

Boersma, K. F., Eskes, H. J., Veefkind, J. P., Brinksma, E. J., van der A, R. J., Sneep, M., van den Oord, G. H. J., Levelt, P. F., Stammes, P., Gleason, J. F., and Bucsela, E. J.: Near-real time retrieval of tropospheric NO2 from OMI, Atmos. Chem. Phys., 7, 2103-2118, doi:10.5194/acp-7-2103-2007, 2007.

Boersma, K. F., Jacob, D. J., Bucsela, E. J., Perring, A. E., Dirksen, R., Van der A, R. J., Yantosca, R. M., Park, R. J., Wenig, M. O., Bertram, T. H., and Cohen, R. C.: Validation of OMI tropospheric NO2 observations during INTEX-B and application to constrain NOx emissions over the eastern United States and Mexico, Atmos. Environm., 42(19), 44804497, doi:10.1016/j.atmosenv.2008.02.004, 2008.

Boersma, K. F., Dirksen, R. J., Veefkind, J. P., Eskes, H. J., and Van der A, R. J.: Dutch OMI NO2 (DOMINO) data product, HE5 data file user manual, Tech. rep., KNMI, 2009.

Bönisch, H., Hoor, P., Gurk, C., Feng, W., Chipperfield, M., Engel, A., and Bregman, B.: Model evaluation of $\mathrm{CO}_{2}$ and $\mathrm{SF}_{6}$ in the extratropical UT/LS region, J. Geophys. Res., 113, D06101, doi:10.1029/2007JD008829, 2008.

Bouwman, A. F., Lee, D. S., Asman, W. A. H., Dentener, F. J., Van der Hoek, K. W., and Olivier, J. G. J.: A global high-resolution emission inventory for ammonia, Global Biogeochem. Cycles, 11(4), 561-588, 1997.

Bregman, B., Segers, A., Krol, M., Meijer, E., and van Velthoven, P.: On the use of mass-conserving wind fields in chemistry-transport models, Atmos. Chem. Phys., 3, 447-457, doi:10.5194/acp-3-447-2003, 2003.

Brühl, C. and Crutzen, P. J.: Scenarios of possible changes in atmospheric temperatures and ozone concentrations due to man's activities, estimated with a one-dimensional coupled photochemical climate model, Clim. Dynam., 2, 173-203, 1988.

Chin, M., Jacob, D. J., Gardner, G. M., Foreman-Fowler, M. S., Spiro, P. A., and Savoie, D. L.: A global three-dimensional model of tropospheric sulphate, J. Geophys. Res., 101(D13), 18667-18690, 1996.

Corbett, J. J. and Koehler, H. W.: Updated emissions from ocean shipping, J. Geophys. Res., 108(D20), 4650, doi:10.1029/2003JD003751, 2003.

Dameris, M., Grewe, V., Ponater, M., Deckert, R., Eyring, V., Mager, F., Matthes, S., Schnadt, C., Stenke, A., Steil, B., Brühl, C., and Giorgetta, M. A.: Long-term changes and variability in a transient simulation with a chemistry-climate model employing realistic forcing, Atmos. Chem. Phys. Discuss., 5, 2297-2353, doi:10.5194/acpd-5-2297-2005, 2005.

de Laat, A. T. J., van der A, R. J., and van Weele, M.: Evaluation of tropospheric ozone columns derived from assimilated GOME ozone profile observations, Atmos. Chem. Phys., 9, 8105-8120, doi:10.5194/acp-9-8105-2009, 2009.

de Meij, A., Krol, M., Dentener, F., Vignati, E., Cuvelier, C., and Thunis, P.: The sensitivity of aerosol in Europe to two different emission inventories and temporal distribution of emissions, Atmos. Chem. Phys., 6, 4287-4309, doi:10.5194/acp-6-4287-2006, 2006.

Dentener, F. J. and Crutzen, P. J.: Reaction of $\mathrm{N}_{2} \mathrm{O}_{5}$ on tropospheric aerosols: Impact on the global distributions of $\mathrm{NO}_{\mathrm{x}}, \mathrm{O}_{3}$ and $\mathrm{OH}$, J. Geophys. Res., 98(D4), 7149-7163, 1993.

Dentener, F., van Weele, M., Krol, M., Houweling, S., and van Velthoven, P.: Trends and inter-annual variability of methane emissions derived from 1979-1993 global CTM simulations, Atmos. Chem. Phys., 3, 73-88, doi:10.5194/acp-3-73-2003, 2003.

Dentener, F., Stevenson, D., Ellingsen, K., Van Noije, T., Schultz, M., et al.: The global atmospheric environment for the next generation, Environ. Sci. Technol., 40(11), 3586-3594, doi:10.1021/es0523845, 2006a.

Dentener, F., Kinne, S., Bond, T., Boucher, O., Cofala, J., Generoso, S., Ginoux, P., Gong, S., Hoelzemann, J. J., Ito, A., Marelli, L., Penner, J. E., Putaud, J.-P., Textor, C., Schulz, M., van der Werf, G. R., and Wilson, J.: Emissions of primary aerosol and precursor gases in the years 2000 and 1750 prescribed data-sets for AeroCom, Atmos. Chem. Phys., 6, 4321-4344, doi:10.5194/acp6-4321-2006, 2006b.

Dentener, F., Drevet, J., Lamarque, J. F., et al.: Nitrogen and sulfur deposition on regional and global scales: a multimodel evaluation, Global Biogeochem. Cycles, 20, GB4003, doi:10.1029/2005GB002672, 2006c.

Deeter, M. N., Edwards, D. P., Gille, J. C., Emmons, L. K., Francis, G., Ho, S.-P., Mao, D., Masters, D., and Worden, H., Drummond, J. R., and Novelli, P. C.: The MOPITT version 4 CO product: Algorithm enhancements, validation, and long-term stability, J. Geophys. Res., 115, D07306, doi:10.1029/2009JD013005, 2010. 
De Smedt, I., Müller, J.-F., Stavrakou, T., van der A, R., Eskes, H., and Van Roozendael, M.: Twelve years of global observations of formaldehyde in the troposphere using GOME and SCIAMACHY sensors, Atmos. Chem. Phys., 8, 4947-4963, doi:10.5194/acp-8-4947-2008, 2008.

Elterman, L.: UV, visible and IR attenuation for altitudes to 50 km, Environmental Research Papers, No. 285, Report 68-0153, Air Force Cambridge Research Laboratories, Bedford, Massachusetts, United States, 1968.

Endresen, Ø., Sørgård, E., Sundet, J. K., Dalsøren, S. B., Isaksen, I. S. A., Berglen, T. F., and Gravir, G.: Emission from international sea transportation and environmental impact, J. Geophys. Res., 108(D17), 4560, doi:10.1029/2002JD002898, 2003.

Evans, M. J. and Jacob, D. J.: Impact of new laboratory studies of $\mathrm{N}_{2} \mathrm{O}_{5}$ hydrolysis on global model budgets of tropospheric nitrogen oxides, ozone and $\mathrm{OH}$, Geophys. Res. Lett., 32, doi:10.1029/2005GL022469, 2005.

Fiore, A. M., Dentener, F. J., Wild, O., et al.: Multimodel estimates of intercontinental source-receptor relationships for ozone pollution, J. Geophys. Res., 114, D4, doi:10.1029/2008JD010816, 2009.

Flemming, J., Inness, A., Flentje, H., Huijnen, V., Moinat, P., Schultz, M. G., and Stein, O.: Coupling global chemistry transport models to ECMWF's integrated forecast system, Geosci. Model Dev., 2, 253-265, doi:10.5194/gmd-2-253-2009, 2009.

Fortuin, J. P. F. and Kelder, H.: An ozone climatology based on ozonesonde and satellite measurements. J. Geophys. Res., 103, 31709-31734, 1998.

$\mathrm{Fu}, \mathrm{Q} .:$ An accurate parameterization of the solar radiative properties of cirrus clouds for climate models, J. Climate., 9, 20582082, 1996.

Ganzeveld, L. and Lelieveld, J.: Dry deposition parameterization in a chemistry general circulation model and its influence on the distribution of reactive trace gases, J. Geophys. Res., 100(D10), 20999-21012, 1995.

Ganzeveld, L., Lelieveld, J., and Roelofs, G.-J.: A dry deposition parameterization for sulfur oxides in a chemistry and general circulation model, J. Geophys. Res., 103(D5), 5679-5694, doi:10.1029/97JD03077, 1998.

Gery, M., Whitten, G. Z., Killus, J. P., and Dodge, M. C.: A photochemical kinetics mechanism for urban and regional scale computer modelling, J. Geophys. Res., 94, 18925-18956, 1989.

Gloudemans, A. M. S., Krol, M. C., Meirink, J. F., De Laat, A. T. J., Van der Werf, G. R., Schrijver, H., Van den Broek, M. M. P., and Aben, I.: Evidence for long-range transport of carbon monoxide in the Southern Hemisphere from SCIAMACHY observations, Geophys. Res. Lett., 33, L16807, doi:2006GL026804, 2006.

Grooß, J.-U. and Russell III, J. M.: Technical note: A stratospheric climatology for $\mathrm{O}_{3}, \mathrm{H}_{2} \mathrm{O}, \mathrm{CH}_{4}, \mathrm{NO}_{\mathrm{x}}, \mathrm{HCl}$ and $\mathrm{HF}$ derived from HALOE measurements, Atmos. Chem. Phys., 5, 2797-2807, doi:10.5194/acp-5-2797-2005, 2005

Guelle, W., Balkanski, Y. J., Schulz, M., Dulac, F., and Monfray, P.: Wet deposition in a global size-dependent aerosol transport model 1 . Comparison of a 1 year $210 \mathrm{~Pb}$ simulation with ground measurements, J. Geophys. Res., 103(D10), 1142911446, doi:10.1029/97JD03680, 1998.

Guenther, A., Hewitt, C. N., Erickson, D., et al.: A global model of natural volatile organic compound emissions, J. Geophys. Res., 100, 8873-8892, 1995.
Heimann, M., Monfray, P., and Polian, G.: Long-range transport of 222Rn- a test for 3D tracer models, Chem. Geol., 70, 98-98, 1988.

Hains, J., Boersma, K. F., Kroon, M., et al.: Testing and improving OMI DOMINO tropospheric NO2 using observations from the DANDELIONS and INTEX-B validation campaigns, J. Geophys. Res., 115, D05301, doi:10.1029/2009JD012399, 2010.

Hales, J. M. and Drewes, D. R.: Solubility of ammonia in water at low concentrations, Atmos. Environ., 13, 1133-1147, 1979.

Hazeleger, W., Severijns, C., Semmler, T., et al.: EC-Earth: A seamless Earth system prediction approach in action, B. Am. Meteorol. Soc., accepted, doi:10.1175/2010BAMS2877.1, 2010.

Hertel, O., Berkowicz, R., and Christensen, J.: Test of two numerical schemes for use in atmospheric transport-chemistry models Atmos. Environ., 27A(16), 2591-2611, 1993.

Heymsfield, A. J. and McFarquhar, G. M.: High albedos of cirrus in the tropical pacific warm pool: Microphysical interpretations from CEPEX and from Kwajalein, Marshall Islands, J. Atmos. Sci., 53, 2424-2451, 1996.

Holtslag, A. A. and Boville, B. A.: Local versus nonlocal boundarylayer diffusion in a global climate model, J. Climate, 10, 18251842, 1993.

Houweling, S., Dentener, F. J., and Lelieveld, J.: The impact of nonmethane hydrocarbon compounds on tropospheric photochemistry, J. Geophys. Res., 103(D9), 10673-10696, 1998.

Huang, H.-C. and Chang, J. S.: On the performance of numerical solvers for a chemistry submodel in three-dimensional air quality models 1 . Box model simulations, J. Geophys. Res., 106, doi:10.1029/2000JD000121, 2001.

Huijnen, V., Eskes, H. J., Poupkou, A., Elbern, H., Boersma, K. F., Foret, G., Sofiev, M., Valdebenito, A., Flemming, J., Stein, O., Gross, A., Robertson, L., D’Isidoro, M., Kioutsioukis, I., Friese, E., Amstrup, B., Bergstrom, R., Strunk, A., Vira, J., Zyryanov, D., Maurizi, A., Melas, D., Peuch, V.-H., and Zerefos, C.: Comparison of OMI NO2 tropospheric columns with an ensemble of global and European regional air quality models, Atmos. Chem. Phys., 10, 3273-3296, doi:10.5194/acp-10-3273-2010, 2010.

IPCC (Intergovernmental Panel on Climate Change): Special report on aviation and the global atmosphere, edited by: Penner, J. E., Lister, D. H., Griggs, D. J., Dokken, D. J., and McFarland, M., Cambridge University Press, Cambridge, United Kingdom and New York, NY, USA, 373 pp., 1999.

Jeuken, A., Veefkind, J. P., Dentener, F., Metzger, S., and Gonzalez, C. R.: Simulation of the aerosol optical depth over Europe for August 1997 and a comparison with observations, J. Geophys. Res., 106(D22), 28295-28311, 2001.

Kopacz, M., Jacob, D. J., Fisher, J. A., Logan, J. A., Zhang, L., Megretskaia, I. A., Yantosca, R. M., Singh, K., Henze, D. K., Burrows, J. P., Buchwitz, M., Khlystova, I., McMillan, W. W., Gille, J. C., Edwards, D. P., Eldering, A., Thouret, V., and Nedelec, P.: Global estimates of CO sources with high resolution by adjoint inversion of multiple satellite datasets (MOPITT, AIRS, SCIAMACHY, TES), Atmos. Chem. Phys., 10, 855-876, doi:10.5194/acp-10-855-2010, 2010.

Krol, M. C. and van Weele, M.: Implications of variations in photodissociation rates for global tropospheric chemistry, Atmos. Environ., 31, 1257-1273, 1997.

Krol, M. C. and Lelieveld, J.: Can the variability in tropospheric $\mathrm{OH}$ be deduced from measurements of $1,1,1$ 
trichloroethane (methyl chloroform)?, J. Geophys. Res., 108, 4125, doi:10.1029/2002JD002423, 2003.

Krol, M., Houweling, S., Bregman, B., van den Broek, M., Segers, A., van Velthoven, P., Peters, W., Dentener, F., and Bergamaschi, P.: The two-way nested global chemistry-transport zoom model TM5: algorithm and applications, Atmos. Chem. Phys., 5, 417432, doi:10.5194/acp-5-417-2005, 2005.

Krol, M. C., Meirink, J. F., Bergamaschi, P., Mak, J. E., Lowe, D., Jöckel, P., Houweling, S., and Röckmann, T.: What can ${ }^{14} \mathrm{CO}$ measurements tell us about OH?, Atmos. Chem. Phys., 8, 50335044, doi:10.5194/acp-8-5033-2008, 2008.

De Laat, A. T. J., Landgraf, J., Aben, I., Hasekamp, O., and Bregman, B.: Validation of Global Ozone Monitoring Experiment ozone profiles and evaluation of stratospheric transport in a global chemistry transport model, J. Geophys. Res., 112, D05301, doi:10.1029/2005JD006789, 2007.

Labonne, M., Breon, F.-M., and Chevallier, F.: Injection heights of biomass burning aerosols as seen from a space borne lidar, Geophys. Res. Lett., 34, L11806, doi:10.1029/2007GL029311, 2007.

Lamsal, L. N., Martin, R. V., Van Donkelaar, A., Celarier, E. A., Bucsela, E. J., Boersma, K. F., Dirksen, R., Luo, C., and Wang, Y.: Indirect validation of tropospheric nitrogen dioxide retrieved from the OMI satellite instrument: Insight into the seasonal variation of nitrogen oxides at Northern midlatitudes, J. Geophys. Res., 115, D05302, doi:10.1029/2009JD013351, 2010.

Landgraf, J. and Crutzen, P. J.: An efficient method for online calculations of photolysis and heating trates, J. Atmos. Sci., 55, 863878,1998

Lathière, J., Hauglustaine, D. A., Friend, A. D., De NobletDucoudré, N., Viovy, N., and Folberth, G. A.: Impact of climate variability and land use changes on global biogenic volatile organic compound emissions, Atmos. Chem. Phys., 6, 2129-2146, doi:10.5194/acp-6-2129-2006, 2006.

Law, R. M., Peters, W., Rödenbeck, C., et al.: TransCom model simulations of hourly atmospheric $\mathrm{CO} 2$ : Experimental overview and diurnal cycle results for 2002, Global Biogeochem Cy., 22, GB3009, doi:10.1029/2007GB003050, 2008.

Lind, J. A. and Kok, G. L.: Correction to "Henry's law determinations for aqueous solution of hydrogen peroxide, methylhydroperoxide, and peroxyacetic acid" by John A. Lind and Gregory L. Kok, J. Geophys. Res., 99D, 21119, 1994.

Liss, P. S. and Merlivat, L.: Air-sea gas exchange rates: Introduction and synthesis, in: The role of air-sea exchange in geochemical cycling, edited by: Buat-Ménard, P., pp. 113-127, D. Reidel, Dordrecht, The Netherlands, 1986.

Van Loon, M., Vautard, R., Schaap, M., et al.: Evaluation of longterm ozone simulations from seven regional air quality models and their ensemble, Atmos. Environ., 41, 2083-2097, 2007.

Louis, J. F.: A parametric model of vertical eddy fluxes in the atmosphere, Bound.-Layer Meteor., 17, 187-202, 1979.

Marenco, A., Thouret, V., Nedelec, P., et al.: Measurement of ozone and water vapor by Airbus in-service aircraft: The MOZAIC airborne program, An overview, J. Geophys. Res., 103(D19), 25631-25642, 1998.

Meijer, E. W., van Velthoven, P. F. J., Brunner, D. W., Huntrieser, H., and Kelder, H.: Improvement and evaluation of the parameterisation of nitrogen oxide production by lightning, Phys.Chem. Earth, 26(8), 557-583, 2001.
Meirink, J. F., Bergamaschi, P., Frankenberg, C., et al.: Fourdimensional variational data assimilation for inverse modelling of atmospheric methane emissions: Analysis of SCIAMACHY observations, J. Geophys. Res., 113, D17301, doi:10.1029/2007JD009740, 2008.

Metzger, S., Dentener, F., Krol, M. C., Jeuken, A., and Lelieveld, J.: Gas/aerosol partitioning 2. Global modeling results, J. Geophys. Res., 107(D16), 4313, doi:10.1029/2001JD001103, 2002.

Monge-Sanz, B. M., Chipperfield, M. P., Simmons, A. J., Uppala, S. M.: Mean age of air and transport in a CTM: Comparison of different ECMWF analyses, Geophys. Res. Lett., 34(4), doi:10.1029/2006GL028515, 2007

Ohara, T., Akimoto, H., Kurokawa, J., Horii, N., Yamaji, K., Yan, X., and Hayasaka, T.: An Asian emission inventory of anthropogenic emission sources for the period 1980-2020, Atmos. Chem. Phys., 7, 4419-4444, doi:10.5194/acp-7-4419-2007, 2007.

Ordóñez, C., Elguindi, N., Stein, O., Huijnen, V., Flemming, J., Inness, A., Flentje, H., Katragkou, E., Moinat, P., Peuch, V.-H., Segers, A., Thouret, V., Athier, G., van Weele, M., Zerefos, C. S., Cammas, J.-P., and Schultz, M. G.: Global model simulations of air pollution during the 2003 European heat wave, Atmos. Chem. Phys., 10, 789-815, doi:10.5194/acp-10-789-2010, 2010.

Perring, A. E., Bertram, T. H., Farmer, D. K., Wooldridge, P. J., Dibb, J., Blake, N. J., Blake, D. R., Singh, H. B., Fuelberg, H., Diskin, G., Sachse, G., and Cohen, R. C.: The production and persistence of $\Sigma \mathrm{RONO}_{2}$ in the Mexico City plume, Atmos. Chem. Phys., 10, 7215-7229, doi:10.5194/acp-10-7215-2010, 2010.

Peters, W., Krol, M. C., Dlugokencky, E. J., et al.: Toward regionalscale modeling using the two-way nested global model TM5: Characterization of transport using $\mathrm{SF}_{6}$, J. Geophys. Res., 109, D19314, doi:10.1029/2004JD005020, 2004.

Peters, W., Krol, M. C., Van der Werf, G. R., et al.: Seven years of recent European net terrestrial carbon dioxide exchange constrained by atmospheric observations, Global Change Biology, 16(4), p. 1317, doi:10.1111/j.1365-2486.2009.02078.x, 2009.

Prather, M.: Numerical advection by conservation of second-order moments, J. Geophys. Res., 91, 6671-6681, 1986.

Prather, M., Ehhalt, D., Dentener, F., et al.: Atmospheric chemistry and greenhouse gases, in: Climate Change 2001: The scientific basis, contribution of working group 1 to the Third Assessment Report of the Intergovernmental Panel on Climate Change, edited by: Houghton, J. T., Ding, Y., Griggs, D.J., et al., pp. 239288, Cambridge Univ. Press, New York, 2001.

Price, C. and Rind, D.: What determines the cloud-to-ground fraction of lightning in thunderstorms?, Geophys. Res. Lett., 20, 463-466, 1993.

Price, C., Penner, J., and Prather, M.: NOx from lightning 1. Global distribution based on lightning physics, J. Geophys. Res., 102, 5929-5941, 1997.

Prinn, R. G., Huang, J., Weiss, R. F., Cunnold, D. M., Fraser, P. J., et al.: Evidence for variability of atmospheric hydroxyl radicals over the past quarter century, Geophys. Res. Lett., 32, L07809, doi:10.1029/2004GL022228, 2005.

Roberts, J. M. and Fayer, R. W.: UV absorption cross section of organic nitrates of potential atmospheric importance and estimation of atmospheric lifetimes, Environ. Sci. Technol., 23, 945951, 1989. 
Roelofs, G.-J. and Lelieveld, J.: Distribution and budget of O3 in the troposphere calculated with a chemistry-general circulation model, J. Geophys. Res., 100, 20983-20998, 1995.

Russell, G. L. and Lerner, J. A.: A new finite-differencing scheme for the tracer transport equation, J. Appl. Meteorol., 20, 14831498, 1981.

Sander, R.: Compilation of Henry's Law Constants for Inorganic and Organic Species of Potential Importance in Environmental Chemistry (Version 3), http://www.henrys-law.org, 1999.

Sander, S. P., Friedl, R. R., Ravishankara, A. R., et al.: Chemical kinetics and photochemical data for use in atmospheric studies, Evaluation no. 15, Technical report JPL-Publ-06-2, Jet Propulsion Laboratory, Pasadena, California, United States, 2006.

Schmitt, A. and Brunner, B.: Emissions from aviation and their development over time, in: Pollutants from air traffic - results of atmospheric research 1992-1997, DLR-Mitt. 97-04, edited by: Schumann, U., Chlond, A., Ebel, A., Kärcher, B., Pate, H., Schlager, H., Schmitt, A., and Wendling, P., 37-52, DLR Köln, Germany, 1997.

Schmitt, C. G. and Heymsfield, A. J.: Total surface area estimates for individual ice particles and particle populations, J. Appl. Meteorol., 44, 467-474, 2005.

Schultz, M. G., Backman, L., Balkanski, Y., et al.: REanalysis of the TROpospheric chemical composition over the past 40 years (RETRO) - A long-term global modeling study of tropospheric chemistry, Final Report, Jülich/Hamburg, Germany, 2007 (Published as report no. 48/2007 in the series "Reports on Earth System Science" of the Max Planck Institute for Meteorology, Hamburg, ISSN 1614-1199), 2007.

Schumann, U. and Huntrieser, H.: The global lightning-induced nitrogen oxides source, Atmos. Chem. Phys., 7, 3823-3907, doi:10.5194/acp-7-3823-2007, 2007.

Segers, A., van Velthoven, P., Bregman, B., and Krol, M.: On the computation of mass fluxes for Eulerian transport models from spectral meteorological fields, in: Proceedings of the 2002 International Conference on Computational Science, edited by: Sloot, P., Tan, C. K., Dongarra, J., and Hoekstra, A., volume 2330/2002 of Lecture Notes in Computer Science (LNCS), pages 767-776, Springer Verlag, 2002

Shetter, R. E., Cantrell, C. A., Lantz, K. O., et al.: Actinometric and radiometric measurement and modeling of the photolysis rate coefficient of ozone to $\mathrm{O}(1 \mathrm{D})$ during the Mauna Loa Observatory Photochemistry Experiment 2, J. Geophys. Res., 101(D9), 14631-14642, 1996.

Shindell, D. T., Faluvegi, G., Stevenson, D. S., et al.: Multimodel simulations of carbon monoxide: Comparison with observations and projected near-future changes, J. Geophys. Res., 111, D19306, doi:10.1029/2006JD007100, 2006.

Sillén, L. G. and Martell, A. E.: Stability constants of metal-ion complexes, Spec. Publ. No. 17, The Chemical Society, London, 1964.

Singh, H. B., Brune, W. H., Crawford, J. H., Flocke, F., and Jacob, D. J.: Chemistry and transport of pollution over the Gulf of Mexico and the Pacific: spring 2006 INTEX-B campaign overview and first results, Atmos. Chem. Phys., 9, 2301-2318, doi:10.5194/acp-9-2301-2009, 2009.

Spiro, P., Jacob, D., and Logan, J.: Global inventory of sulfur emissions with $1^{\circ} \times 1^{\circ}$ resolution, J. Geophys. Res., 97, 6023-6036, 1992.
Spivakovsky, C. M., Logan, J. A., Montzka, S. A., et al.: Threedimensional climatological distribution of tropospheric $\mathrm{OH}$ : Update and evaluation, J. Geophys. Res., 105(D7), 8931-8980, 2000.

Stavrakou, T., Müller, J.-F., De Smedt, I., Van Roozendael, M., van der Werf, G. R., Giglio, L., and Guenther, A. Global emissions of non-methane hydrocarbons deduced from SCIAMACHY formaldehyde columns through 2003-2006, Atmos. Chem. Phys., 9, 3663-3679, doi:10.5194/acp-9-3663-2009, 2009.

Stevenson, D. S., Dentener, F. J., Schultz, M. G., et al.: Multimodel ensemble simulations of present-day and nearfuture tropospheric ozone, J. Geophys. Res., 111, D08301, doi:10.1029/2005JD006338, 2006.

O'Sullivan, D. W., Lee, M., Noone, B. C., and Heikes, B. G.: Henry's law constant determinations for hydrogen peroxide, methyl hydroperoxide, hydroxymethyl hydroperoxide, ethyl hydroperoxide and peroxyacetic acid, J. Phys. Chem., 100(8), 3241-3247, 1996.

Thornton, J. A., Wooldridge, P. J., and Cohen, R. C.: Atmospheric NO2: In Situ Laser-Induced Fluorescence Detection at Parts per Trillion Mixing Ratios, Analytical Chemistry, 72, 528-539, 2000.

Thouret, V., Marenco, A., Logan, J., Nédélec, P., and Grouhel, C.: Comparisons of ozone measurements from the MOZAIC airborne program and the ozone sounding network at eight locations, J. Geophys. Res., 103(D14), 25695-25720, 1998.

Tiedtke, M.: A comprehensive mass flux scheme for cumulus parameterization in large-scale models, Mon. Weather. Rev., 117(8), 1779-1800, 1989.

Van Noije, T. P. C., Eskes, H. J., van Weele, M., and van Velthoven, P. F. J.: Implications of the enhanced Brewer-Dobson circulation in European Centre for Medium-Range Weather Forecasts reanalysis ERA-40 for the stratosphere-troposphere exchange of ozone in global chemistry transport models, J. Geophys. Res., 109, D19308, doi:10.1029/2004JD004586, 2004.

van Noije, T. P. C., Eskes, H. J., Dentener, F. J., Stevenson, D. S., Ellingsen, K., Schultz, M. G., Wild, O., Amann, M., Atherton, C. S., Bergmann, D. J., Bey, I., Boersma, K. F., Butler, T., Cofala, J., Drevet, J., Fiore, A. M., Gauss, M., Hauglustaine, D. A., Horowitz, L. W., Isaksen, I. S. A., Krol, M. C., Lamarque, J.-F., Lawrence, M. G., Martin, R. V., Montanaro, V., Müller, J.F., Pitari, G., Prather, M. J., Pyle, J. A., Richter, A., Rodriguez, J. M., Savage, N. H., Strahan, S. E., Sudo, K., Szopa, S., and van Roozendael, M.: Multi-model ensemble simulations of tropospheric $\mathrm{NO}_{2}$ compared with GOME retrievals for the year 2000, Atmos. Chem. Phys., 6, 2943-2979, doi:10.5194/acp-62943-2006, 2006a.

Van Noije, T. P. C., Segers, A. J., and van Velthoven, P. F. J.: Time series of the stratosphere-troposphere exchange of ozone simulated with reanalyzed and operational forecast data, J. Geophys Res., 111, D03301, doi:10.1029/2005JD006081, 2006b.

Vignati, E., Wilson, J., and Stier, P.: M7: An efficient size-resolved aerosol microphysics module for large-scale aerosol transport models, J. Geophys. Res., 109, D22202, doi:10.1029/2003JD004485, 2004.

Vignati, E., Karl, M., Krol, M., Wilson, J., Stier, P., and Cavalli, F.: Sources of uncertainties in modelling black carbon at the global scale, Atmos. Chem. Phys., 10, 2595-2611, doi:10.5194/acp-10- 
2595-2010, 2010.

Vogelezang, D. H. P. and Holtslag, A. A. M.: Evaluation and model impacts of alternative boundary-layer height formulations, Bound.-Layer Meteor., 81, 245-269, 1996.

Yarwood, G., Rao, S., Yocke, M., and Whitten, G. Z.: Updates to the carbon bond chemical mechanism: CB05, Report to the US Environmental Protection Agency, RT-04-00675, Yocke and Company, Novato, California, United States, 2005.

van den Broek, M. M. P., van Aalst, M. K., Bregman, A., Krol, M., Lelieveld, J., Toon, G. C., Garcelon, S., Hansford, G. M., Jones, R. L., and Gardiner, T. D.: The impact of model grid zooming on tracer transport in the 1999/2000 Arctic polar vortex, Atmos. Chem. Phys., 3, 1833-1847, doi:10.5194/acp-3-1833-2003, 2003.

van $\operatorname{der}$ A, R. J., Allaart, M. A. F., and Eskes, H. J.: Multi sensor reanalysis of total ozone, Atmos. Chem. Phys. Discuss., 10, 11401-11448, doi:10.5194/acpd-10-11401-2010, 2010.

van der Werf, G. R., Randerson, J. T., Giglio, L., Collatz, G. J., Kasibhatla, P. S., and Arellano Jr., A. F.: Interannual variability in global biomass burning emissions from 1997 to 2004, Atmos. Chem. Phys., 6, 3423-3441, doi:10.5194/acp-6-3423-2006, 2006.

Weseley, M. L.: Parameterization of surface resistance to gaseous dry deposition in regional numerical models, Atmos. Environ., 16, 1293-1304, 1989.

Wild, O. and Prather, M. J.: Global tropospheric ozone modeling: Quantifying errors due to grid resolution, J. Geophys. Res., 111, D11305, doi:10.1029/2005JD006605, 2006.

Williams, J. E. and Van Noije, T. P. C.: On the upgrading of the modified carbon bond mechanism IV for use in global chemistry transport models, Scientific Report WR-2008-02, KNMI, De Bilt, The Netherlands, 2008.
Williams, J. E., Scheele, M. P., van Velthoven, P. F. J., Cammas, J.-P., Thouret, V., Galy-Lacaux, C., and Volz-Thomas, A.: The influence of biogenic emissions from Africa on tropical tropospheric ozone during 2006: a global modeling study, Atmos. Chem. Phys., 9, 5729-5749, doi:10.5194/acp-9-5729-2009, 2009a.

Williams, J. E., van Zadelhoff, G. J., and Scheele, M. P.: The effect of updating scavenging and conversion rates on cloud droplets and ice particles in the TM global chemistry transport model, Technical Report TR-308, KNMI, De Bilt, The Netherlands, 2009b.

Williams, J. E., Scheele, M. P., van Velthoven, P. F. J., Thouret, V., Saunois, M., Reeves, C. E., and Cammas, J.-P.: The influence of biomass burning on tropospheric composition over the tropical Atlantic Ocean and Equatorial Africa during the West African monsoon in 2006, Atmos. Chem. Phys. Discuss., 10, 7507-7552, doi:10.5194/acpd-10-7507-2010, 2010.

Yarwood, G., Rao, S., Yocke, M., and Whitten, G. Z.: Updates to the carbon bond chemical mechanism: CB05, Report to the U.S. Environmental Protection Agency, RT-04-00675, Yocke and Company, Novato, California, United States, 2005.

Zhou, X. and Mopper, K.: Apparent partition coefficients of 15 carbonyl compounds between air and seawater and air and freshwater; Implications for air-sea exchange, Environ. Sci. Technol., 24(12), 1864-1869, 1990.

Zhou, Y., Brunner, D., Boersma, K. F., Dirksen, R., and Wang, P.: An improved tropospheric NO2 retrieval for OMI observations in the vicinity of mountainous terrain, Atmos. Meas. Tech., 2, 401-416, doi:10.5194/amt-2-401-2009, 2009. 